\title{
DESIGN OF A TWO STORY ISO SHIPPING CONTAINER BUILDING
}

\author{
By
}

Mohammad Ataei

B.Eng, IAUTCB, Tehran, Iran 2016

\author{
A MRP \\ presented to Ryerson University \\ in partial fulfillment of the \\ requirements for the degree of \\ Master of Engineering \\ in the program of \\ Civil Engineering
}

Toronto, Ontario, Canada, 2019

(C) Mohammad Ataei, 2019 


\section{Author's Declaration}

I hereby declare that I am the sole author of this MRP. This is a true copy of the MRP, including any required final revisions.

I authorize Ryerson University to lend this MRP to other institutions or individuals for the purpose of scholarly research.

I further authorize Ryerson University to reproduce this MRP by photocopying or by other means, in total or in part, at the request of other institutions or individuals for the purpose of scholarly research.

I understand that my MRP may be made electronically available to the public. 


\begin{abstract}
DESIGN OF A TWO STORY ISO SHIPPING CONTAINER BUILDING

by

Mohammad Ataei

Master of Engineering

Civil Engineering

Ryerson University, Toronto, Canada 2019
\end{abstract}

A container home offers a fast, green, and sustainable approach to building because of its standardized and reliable factory-controlled manufacturing. In this regards, this report investigates the data available in the literature and the strength assessment of ISO shipping container and then goes into the application evaluation of ISO container for temporary and permanent housing options. Real project as a case study has been investigated and all the detailing sheets have been performed. Finally, the conclusion chapter highlights the overall opinion of the author, some suggestions for the ISO container designers and the design challenges which any designer could be faced with. 


\section{Acknowledgment}

First and foremost, I would like to thank Dr. Reza Kianoush for guiding me through every step of this project and always offering his guidance and knowledge.

I would also like to thank Dr. Mehdi Moslemi for helping me with both the analytical analysis and the design process. His experience and assistance offered a great deal of support throughout the project and it could not have been completed without him.

Lastly, I would like to thank Ryerson University for giving me the opportunity to further add to my academic portfolio. 


\section{Dedication}

To my beautiful and smart wife Shanta whose sacrifices, patience, love and support showed no boundaries in helping me achieve this academic milestone. 


\section{Table of contents}

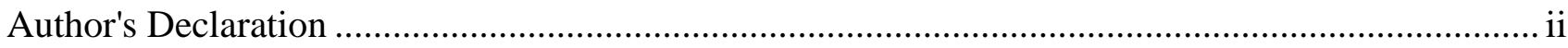

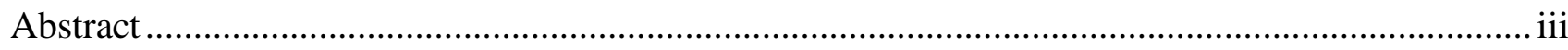

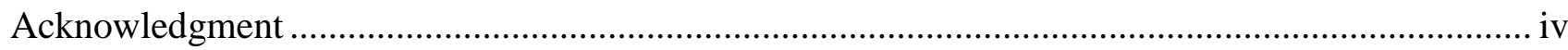

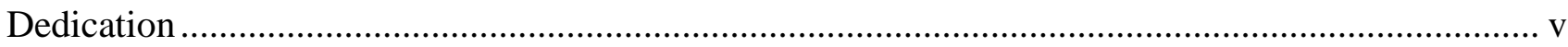

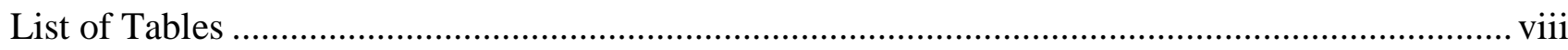

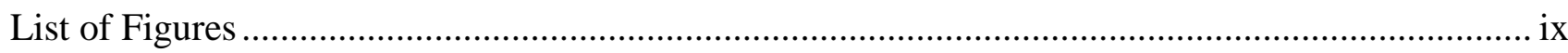

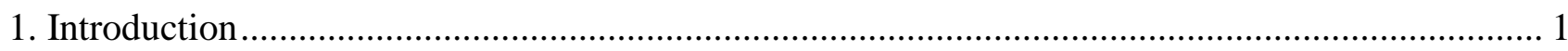

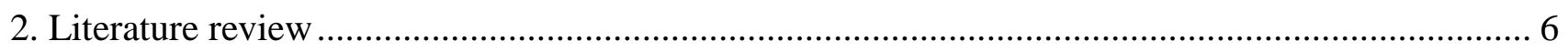

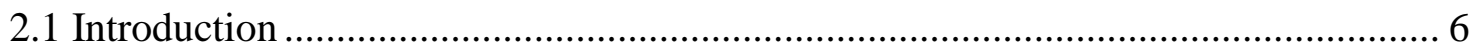

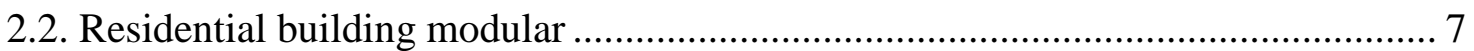

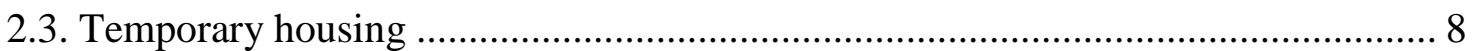

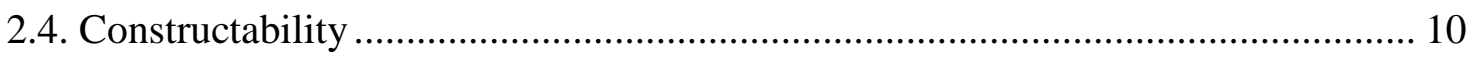

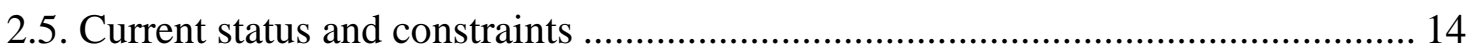

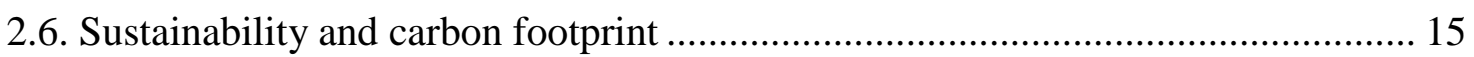

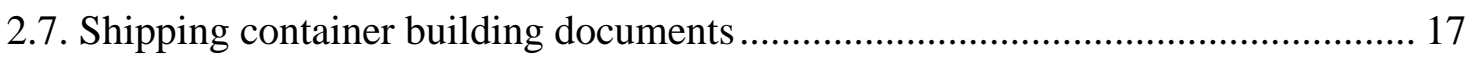

2.7.1 Canadian Standards Association (CSA) ....................................................... 17

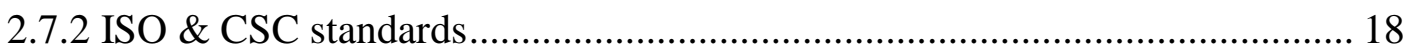

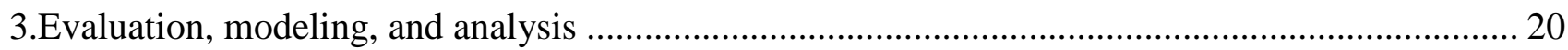

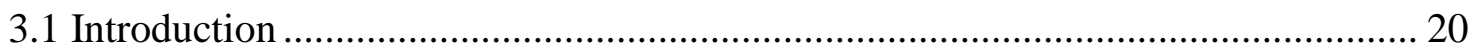

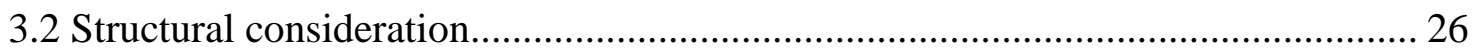

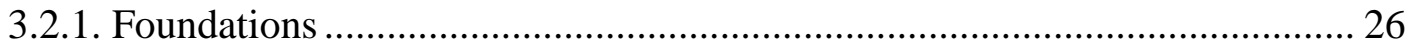

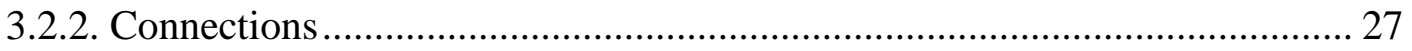

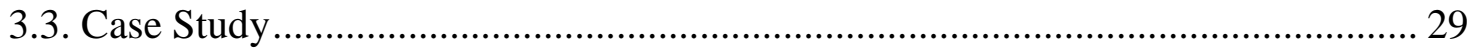

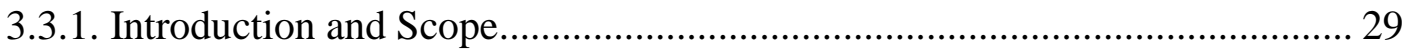

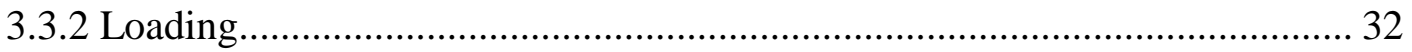

3.3.3 Load Capacities: .................................................................................... 34

3.3.4 Analysis and design........................................................................... 35

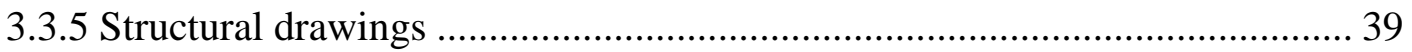

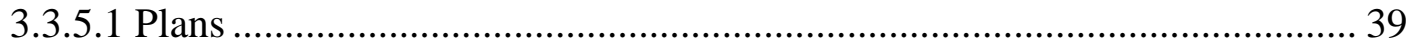

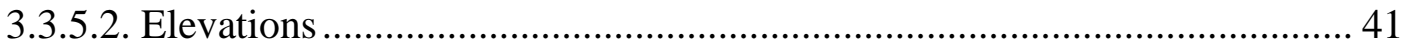

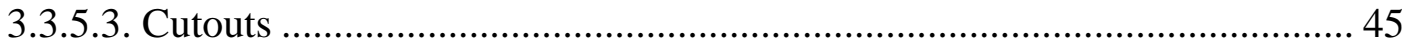

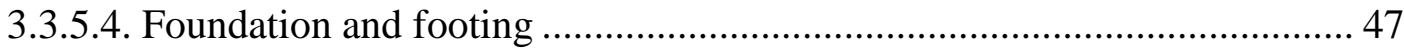

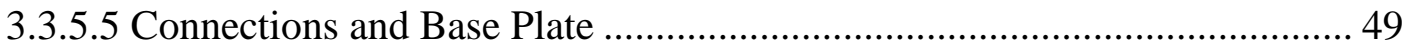


3.3.5.6 Columns 51

4. Discussion and suggestions.

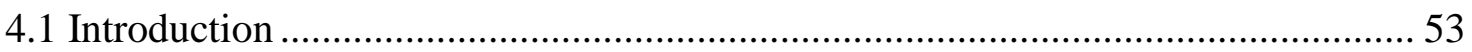

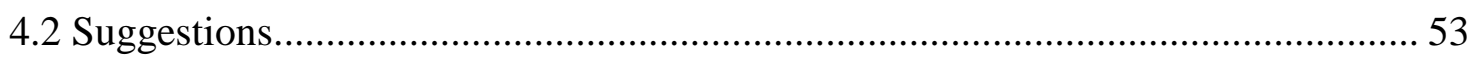

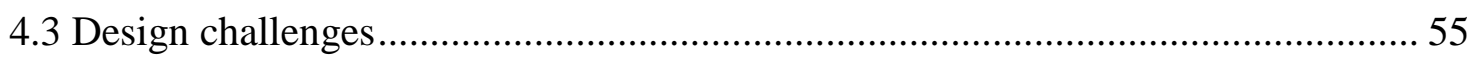

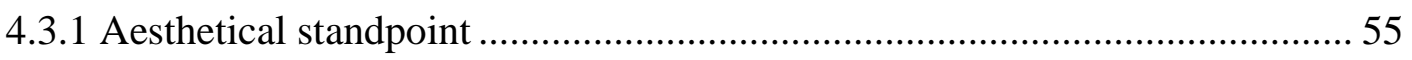

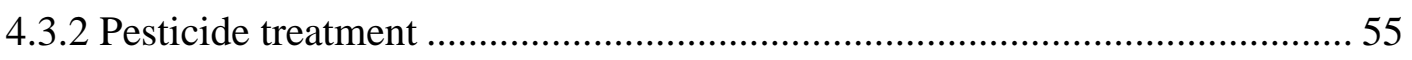

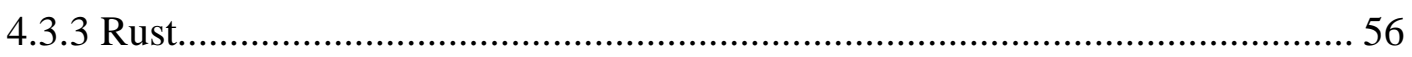

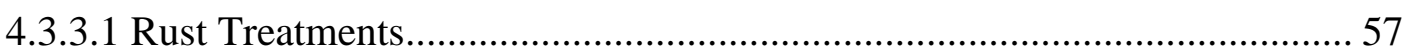

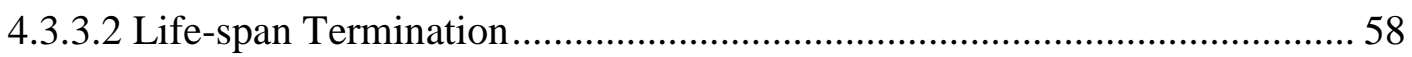

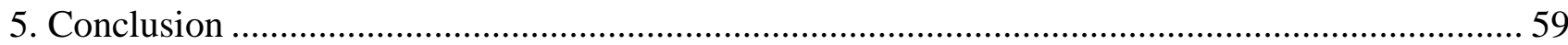

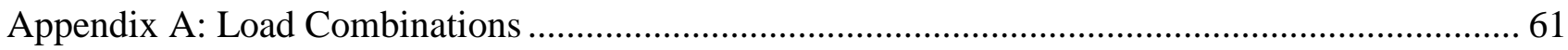

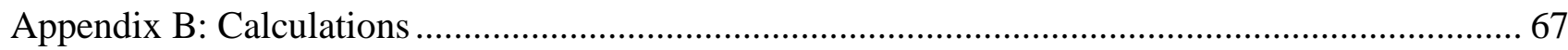

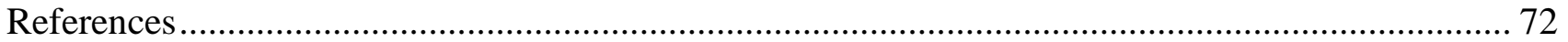




\section{List of Tables}

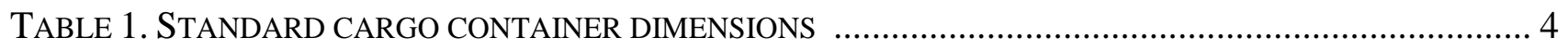

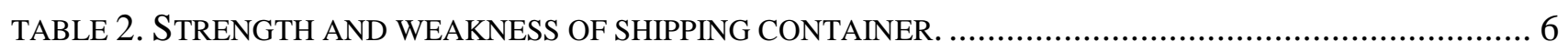

TABLE 3. SUITABILITY ANALYSIS OF SHIPPING CONTAINER FOR TEMPORARY HOUSING....................... 10

TABLE 4. LOAD COMBINATIONS FOR ULTIMATE LIMIT STATE BY NBCC 2015 ................................... 18

TABLE 5. ISO CONTAINER CHARACTERISTICS PROVIDED IN ISO STANDARDS ..................................... 19

TABLE 6. LOAD CAPACITY CHARACTERISTICS OF SHIPPING CONTAINERS. ..................................... 20

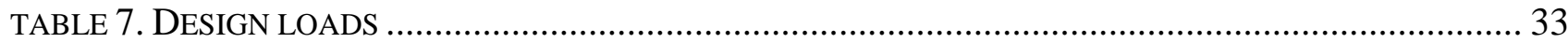

TABLE 8. DEFLECTIONS FOR NODES 1 TO 8 COMPARED IN NON-STRENGTHENED AND STRENGTHENED

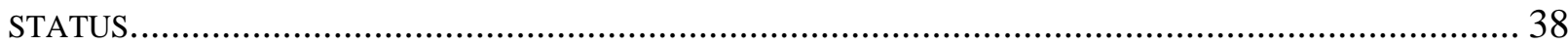

TABLE 9. BILL OF MATERIAL USED IN THE C5W MODIFICATION DRAWINGS. ................................... 44

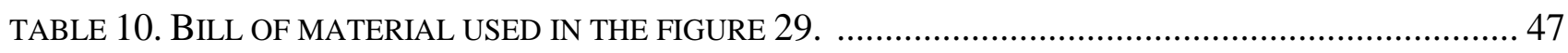

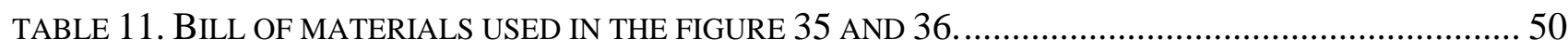

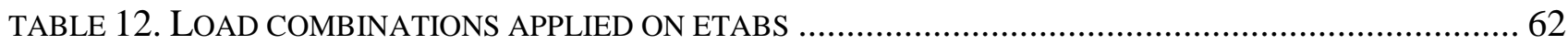

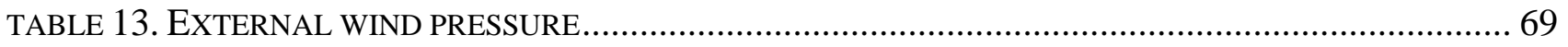




\section{List of Figures}

FIGURE 1. SCHEMATIC ILLUSTRATION OF THE CORROSION PRODUCT LAYERS IDENTIFIED ON STEELS EXPOSED TO RURAL AND MARINE ATMOSPHERE FOR PERIODS OF UP TO FIVE YEARS. ................... 3

FIGURE 2. ILLUSTRATION OF CORNER LOCKING MECHANISM . .............................................. 5

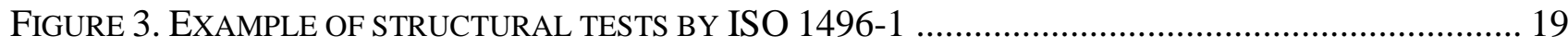

FIGURE 4. 20’ ISO SHIPPING CONTAINERS MODIFICATION MODELS ............................................... 21

FIGURE 5. 20’ LOADING SCENARIOS SIMULATED ON SHIPPING CONTAINER MODELS.......................... 21

FIGURE 6. FLOOR STRUCTURAL DETAILS OF 40’ CONTAINER ................................................... 23

FIGURE 7. FRONT FACE STRUCTURAL DETAILS OF 40’ CONTAINER CONSISTS OF FH AND FCP

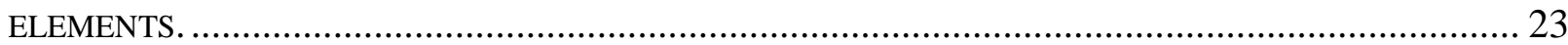

FIGURE 8. FCP AND FH DEFINITION IN FIGURE 7 ............................................................ 24

FIGURE 9. DOOR FACE STRUCTURAL DETAILS OF 40' CONTAINER................................................ 24

FIGURE 10. ROOF FACE STRUCTURAL ELEMENTS OF 40’ CONTAINER ......................................... 25

FIGURE 11. LATERAL FACE STRUCTURAL ELEMENTS OF 40’ CONTAINER....................................... 25

FiguRE 12. (A) CONCRETE BLOCK FOUNDATION, (B) MODIFIED CONTAINER ON BLOCK FOUNDATION.. 27

FIGURE 13. (A) WELDED SHIPPING CONTAINER TO BASE PLATE, (B) UNCOMMON CONNECTION BETWEEN

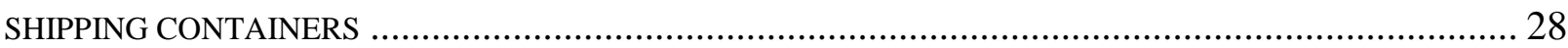

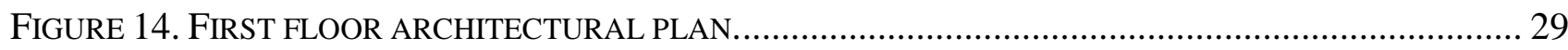

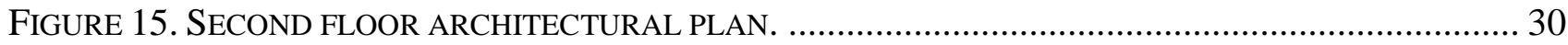

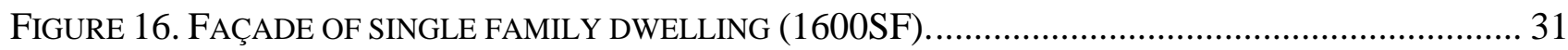

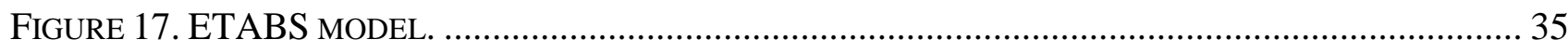

FIGURE 18. DEFORMED SHAPE OF FRAME 1 UNDER LOAD COMBINATION UDSTLS21 ...................... 36

FIGURE 19. EIGHT POINT DEFINED TO COMPARE THE DEFLECTION WITH AND WITHOUT RETROFITTING.

FIGURE 20. SUGGESTED RETROFITTING ELEMENTS DECREASED THE DESIGN RATION OF IN-BUILT

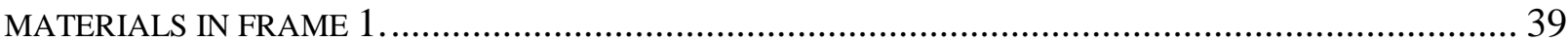

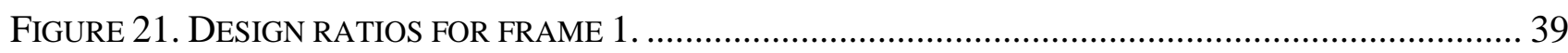

FIGURE 22. TOP: SECOND FLOOR PLAN CONSISTING OF CONTAINER NUMBERS 1, 2 AND 3. BOTTOM: FIRST FLOOR PLAN CONSISTING OF CONTAINER NUMBERS 4, 5 AND 6.................................. 40

Figure 23. TOP: NoRTH ELEVATION, BOTTOM: EAST ELEVATION ........................................... 41

FIGURE 24. C5W PROPOSED STRENGTHENING ELEMENTS .................................................. 42 


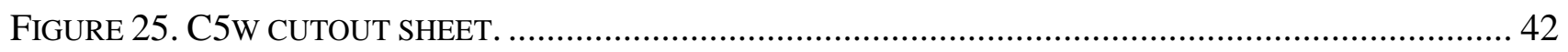

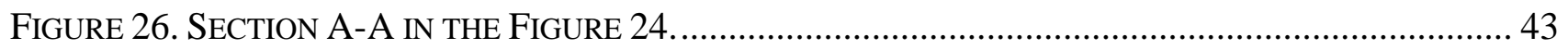

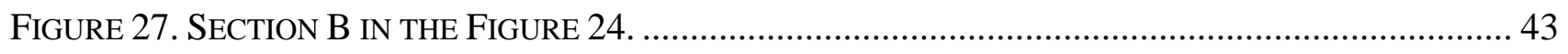

Figure 28. LEFT: SECTION C IN THE FiguRE 24. RIGHT: SECTION D IN THE FiguRE 24.................... 44

FIGURE 29. C4 CONTAINER FLOOR CUTOUT AND FRAMING PLAN …………...................................... 45

Figure 30. LEFT: DetaIL A of Figure 29, RIGHT: DetaIL B of Figure 29 .................................... 46

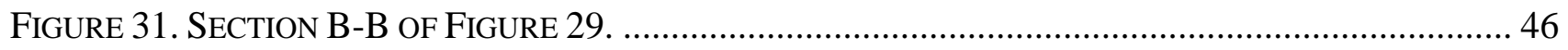

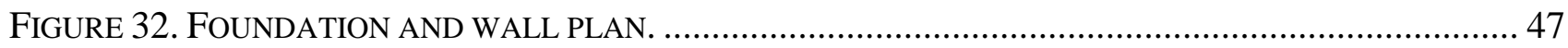

Figure 33. Sections A-A, B-B And C-C OF Figure 30 .................................................................. 48

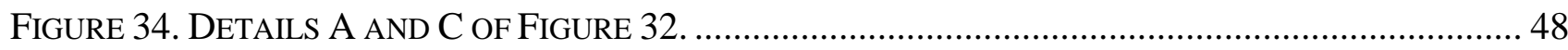

FIGURE 35. NORTH ELEVATION CONNECTION DETAILS ........................................................................ 49

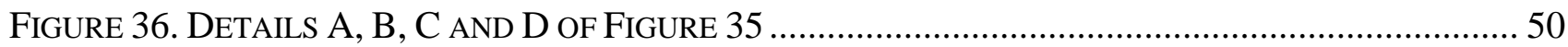

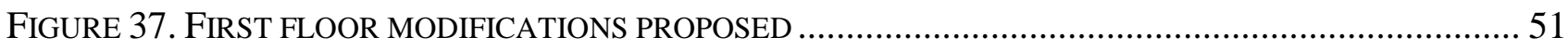

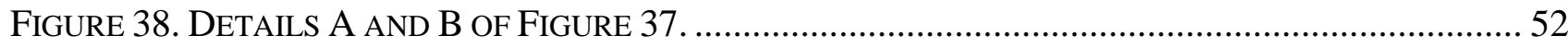

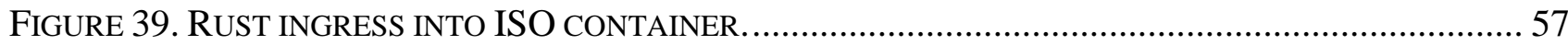




\section{Introduction}

Countries' trade globally uses shipping containers for a worldwide transportation network which produces lots of empty containers at the destination ports. While returning them to the home country may not be economical, leaving them in their new home could take lot of space. So, there are tons of empty containers out there waiting to be reused or recycled. Due to recent development of technological innovation, reuse of shipping containers for home building usage might deserve further investigation between its other usages.

Promising cases of transforming containers to youth center, classroom, emergency shelter, office, house and hotel are emerging around the world each year. This would be a kind of offset in a way, which could result in greener and healthier coastlines without creating another issue in landfill. However, the matter is how to transform those containers sustainably for homebuilding purposes in a way that makes our society greener and healthier.

Some people might not have any idea that shipping containers can be used as home building materials. Reusing shipping containers for house building purposes, reduces the need for newest materials used in conventional construction. It is well established that containers are produced in the same standard dimensions with some inbuilt properties, which makes them a spectacular modular structural component. The recent use of prefabricated shipping containers may be a substitute of traditional timber-framed construction. The study (Vijayalaxmi, 2010) clearly mentioned that this has resulted into a huge drop in embodied energy when compared to conventional houses. Reusing shipping containers are the utmost in sustainability, using far fewer materials and embodied energy than any kind of building construction. For this reason, architects and builders already embarked on 
to take advantage of reusing containers for home building purposes to even be cheaper. However, it is important to investigate its constructability and strength as well as sustainability.

There are also some difficulties of using shipping containers for building structures. Thermal performance of a building may vary due to local climate of the place in which the house is being built. There are obvious opportunities to cut down the embodied energy through the reuse of containers as a construction material. Therefore, it is needed to determine the amount of energy consumption and environmental impacts reduced in container home construction. However, it is also significant to know that how much the container home is habitable compared to a conventional home. It is common thought between critics that because shipping containers were not intended for residency purposes, the operational amount of energy needed to make them habitable would restrict the aspiration of a normal home. The study (Pena \& Schuzer, 2012) mentions that containers walls are relatively thin, uninsulated and acoustically not designed, where comfortability may be a problem to be consider. However, this is not always the case. Measuring of the internal air temperatures of two same dimensioned structures, one being of conventional construction and the other a modular shipping container unit, the study (Vijayalaxmi, 2010) concludes that this form of construction is in fact not inferior to a conventional building. While this might be the case in hot-humid tropical regions, it may require further research being done for cold and temperate climate such Canada.

Serving its life span for freight transport, cargo containers that used for building constructions, are called ISBU which stands for Intermodal Steel Building Unit. Due to sudden change in construction materials and procedures and methods, regulatory officials are yet to recognize shipping containers for home building all around the world. As mentioned, the difficulty of using shipping containers as ISBU is that they are not manufactured in compliance of any building code as some of urban developers were against the development of ISBU construction because of its conflict with present building code roles and regulations (Oloto \& A.Adebayo, 2015). ISBU as a living place is 
expected to be very noisy, and insulating the interior of metal structures requires sound softening elements which could be an extra expense that has to be considered too. However, with the help of latest insulation methods, the performance of the building envelope improves further. Most ISBU are primed with industrial strength anticorrosive coat to avoid surface corrosion or rusting regarding that they are supposed to be carried by ships which is a very humid environment to be in. The study (Fuller, 2006) clearly defines shipping containers structural behavior as that they are intrinsically stiff enough to be stacked up to nine rows high without compromising structural integrity.

Another fundamental element for the reuse of shipping containers in construction are their uniformity and modularity, which buys time for big developer. This prime advantage of reusing these shipping containers identifies the opportunity for efficient and sustainable building construction. These days, the world is moving towards environmental protocols in all industries including building construction which consumes huge energy and emits large amount of green-house gases into the atmosphere. So, reuse of shipping container would open up new prospective into the greener and more sustainable environmental for all of us.

Cargo containers are manufactured from weathering steel. Weathering steel includes alloying elements that affect the materials corrosion procedure. Weathering steel creates an amorphous inner layer that protects the integrity of the steel against external harmful agents. Figure 1 shows the
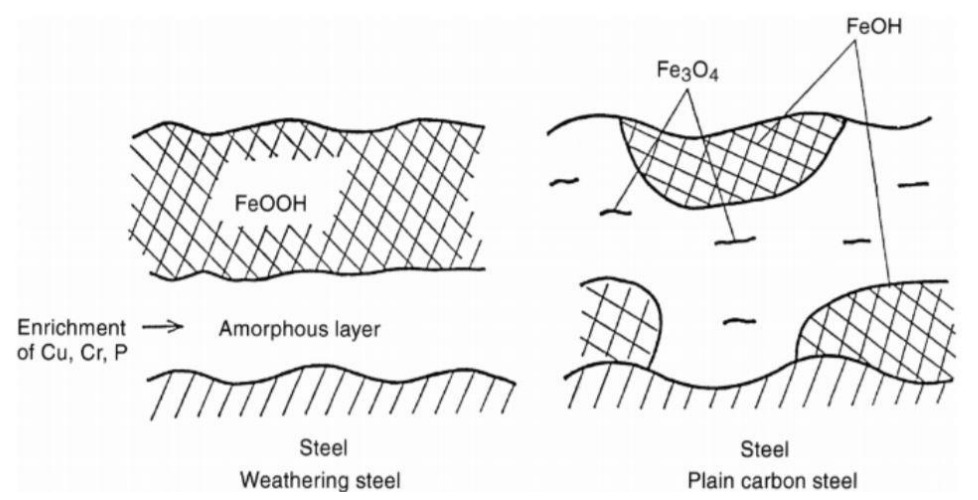

Figure 1. schematic illustration of the corrosion product layers identified on steels exposed to rural and marine atmosphere for periods of up to five years (Moore, Yildirim, \& Baur, 2015). 
placement of the layer as well as its composition. The continuity of the layer also adds to the protection of the steel.

Table 1. standard cargo container dimensions (Moore, Yildirim, \& Baur, 2015).

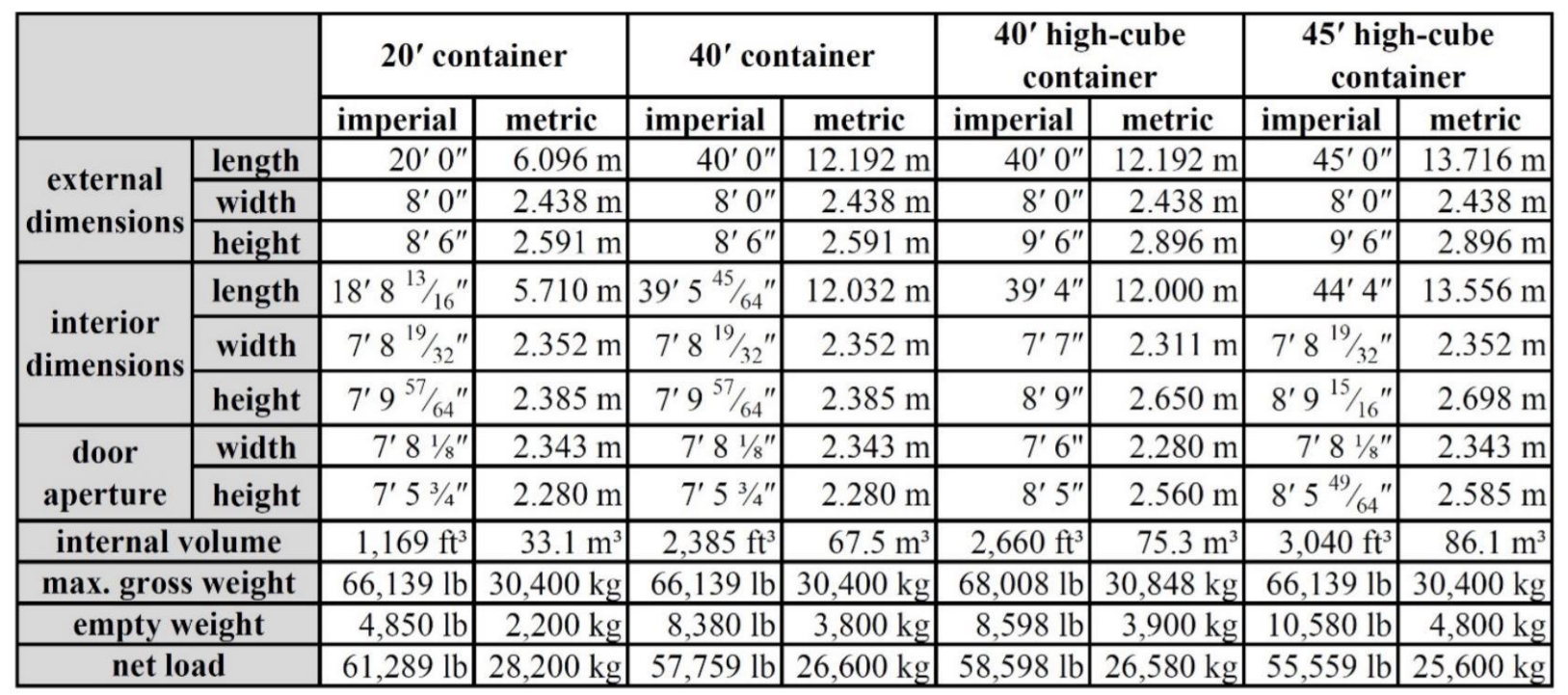

Furthermore, weathering steel is an ideal material for cargo containers due to their exposure to natural elements. Cargo containers spend the majority of their life outdoors on cargo ships, trains and trucks with little protection from moisture. The cargo container is an appealing construction material for a variety of reasons. First, their strength and durability provide both structural support and a long life span. Their weathering steel construction provides not only corrosion protection, but also strength. Also, with a movement toward sustainable construction practices, the recycling of unused cargo containers for construction material puts an unused product to use. Plus, the cargo containers modular construction simplifies the design process. Much like bricks, cargo containers are designed to specific standards. Table 1 above, lists the dimensions of the standard sized containers.

In the practical stacking of the containers in freight need, the interlocking mechanism is used to lock them to each other as can be seen in Figure 2. This mechanism stabilizes the stacked containers 
in case of multi-level container buildings. Moreover, the corner casting of the containers are designed to be connected for the four sides they sit on which could be a foundation advantage at the same time.
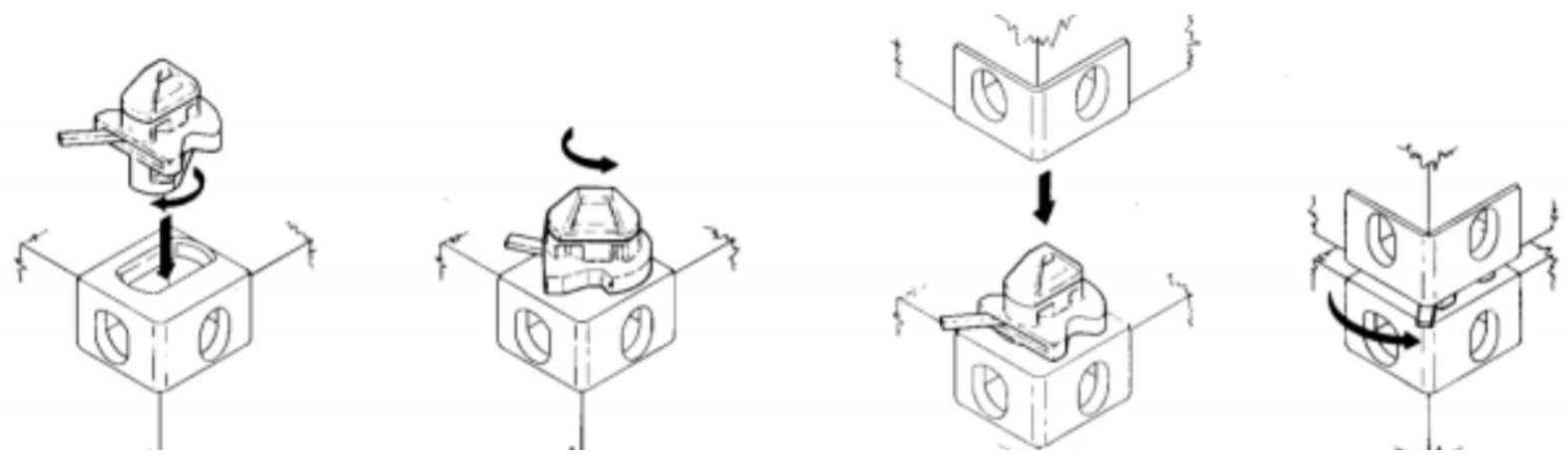

Figure 2. Illustration of corner locking mechanism (Moore, Yildirim, \& Baur, 2015).

ISO shipping containers could be deemed as a perfect construction material due to their high availability. The cost of shipping containers in their origin is more than buying a new one so many of them are left empty in the port all around the world. According to Drewry Maritime Research (drewry.co.uk, 2013), the global container fleet consisted of approximately 32.9 TEU (Twenty-foot Equivalent Unit). That figure would estimate 32.9 million standard 20 foot containers, meaning that there is no shortage of cargo containers in the market today. 


\section{Literature review}

\subsection{Introduction}

Shipping containers are globally applicable building modules in the construction industry. Like other construction methods, shipping containers have both strengths and weaknesses when it comes to the construction site. Some of its advantageous as a reliable construction method are its strength and high durability, modularity, transportability, availability, and cost. To look some of its disadvantageous properties we can mention temperature sensitivity, skilled labor availability, and difficulties with construction sites as can be seen in table 2 .

Table 2. Strength and weakness of shipping container (Brandt, 2011).

\begin{tabular}{|c|c|c|c|}
\hline Feature & Strengths & Weaknesses & Adaption \\
\hline $\begin{array}{c}\text { Strength \& } \\
\text { Durability }\end{array}$ & $\begin{array}{l}\text { Designed to carry heavy loads, } \\
\text { and can thus support multiples of } \\
\text { their own self-weight. They are } \\
\text { also designed to resist harsh } \\
\text { environments while being } \\
\text { transported on ocean going } \\
\text { vessels, trucks, and trains. }\end{array}$ & $\begin{array}{l}\text { Strength is compromised } \\
\text { when shell is modified, } \\
\text { and containers are not } \\
\text { built to carry loads such as } \\
\text { large roofs. While they do } \\
\text { resist the effects of harsh } \\
\text { environments, they are } \\
\text { vulnerable to degradation } \\
\text { caused by natural } \\
\text { elements. }\end{array}$ & $\begin{array}{l}\text { Reinforcement } \\
\text { modifications can be } \\
\text { installed such as } \\
\text { metal or wood } \\
\text { framing to support the } \\
\text { modifications to the } \\
\text { container. Containers } \\
\text { also can be treated } \\
\text { and sealed to resist } \\
\text { the deterioration of } \\
\text { materials and } \\
\text { occasional } \\
\text { maintenance can be } \\
\text { performed as well, } \\
\text { such as de-rusting and } \\
\text { painting. }\end{array}$ \\
\hline
\end{tabular}

Modularity Container's cell-like structure is suitable for layout systems with small rooms, which can be joined together.

Transportability Containers conform to standard shipping sizes allowing them to be easily transported by ship, truck, or rail.
Containers conform

to standard shipping sizes allowing them to be easily transported by ship, truck, or rail. 
Table 3 continued. Strength and weakness of shipping container (Brandt, 2011).

\begin{tabular}{|c|c|c|c|}
\hline Availability & Widely Available & $\begin{array}{l}\text { Site, trade agreements, } \\
\text { and the current need for } \\
\text { containers can alter the } \\
\text { availability of } \\
\text { containers. }\end{array}$ & \\
\hline Cost & $\begin{array}{l}\text { Used containers are available at a } \\
\text { cost that is low compared to a } \\
\text { finished structure built by other } \\
\text { labor-intensive means such as } \\
\text { brick and mortar. }\end{array}$ & $\begin{array}{l}\text { The cost of the container } \\
\text { can increase depending on } \\
\text { the prices of raw materials } \\
\text { used such as steel. }\end{array}$ & \\
\hline Temperature & & $\begin{array}{l}\text { Shipping containers are } \\
\text { made from steel which } \\
\text { conducts heat very well. } \\
\text { In areas of extreme } \\
\text { temperature variations, the } \\
\text { interior of the container } \\
\text { can become } \\
\text { uncomfortable for the use } \\
\text { of human occupancy }\end{array}$ & $\begin{array}{l}\text { By insulating the } \\
\text { container, and } \\
\text { installing HVAC } \\
\text { systems, the interior } \\
\text { environment can } \\
\text { become comfortable } \\
\text { for any environment. }\end{array}$ \\
\hline Labor & $\begin{array}{l}\text { Units are pre-formed so labor is } \\
\text { directed at modification rather } \\
\text { than creation or assemblage }\end{array}$ & $\begin{array}{l}\text { Modifying containers } \\
\text { requires welding and } \\
\text { cutting skills, which are } \\
\text { considered to be a } \\
\text { specialized labor, which } \\
\text { adds to the construction } \\
\text { cost. }\end{array}$ & $\begin{array}{l}\text { Shipping containers } \\
\text { can be shipped with } \\
\text { each module } \\
\text { prefabricated so that a } \\
\text { limited amount of } \\
\text { skilled labor is } \\
\text { required to assemble } \\
\text { the parts. }\end{array}$ \\
\hline Construction Site & & $\begin{array}{l}\text { Maneuvering containers } \\
\text { around a construction site } \\
\text { generally requires the } \\
\text { assistance of a crane or } \\
\text { forklift. }\end{array}$ & $\begin{array}{l}\text { Containers can be } \\
\text { easily oriented on the } \\
\text { site as needed. }\end{array}$ \\
\hline
\end{tabular}

\subsection{Residential building modular}

Shipping containers are offered in different dimensions. For home building applications as shown in Table 1, the most widely used dimensions are $6.0 \mathrm{~m}$ and $12.0 \mathrm{~m}$ long with $2.4 \mathrm{~m}$ width and $2.7 \mathrm{~m}$ high so that the shipping container can provide a better head space with a high ceiling. So, the height of those containers are in compliance with the minimum clear ceiling height $2.4 \mathrm{~m}$ ) required by 
many codes for the construction of home buildings. Containers are named HC (high cube), with commercial names 20’HC-6.0 m long or 40’HC-12 m long. Container are built of composite panels including top and bottom walls, two upright sidewalls and end walls joined at their edges together. The corner posts are being used to join the side and end walls in order to withstand the live and dead loads applied. Containers also compromise of self-supporting beams, stout and plywood flooring. They manufactured of metal sheets to form edges and its grid to support the wooden floor. The corners are rigid pieces to allow the connection between containers which called Corner Casting. To secure the house, the bottom corner castings are usually welded to steel base plates which itself is anchored into the concrete slab of the foundation or retaining wall. The modifications of container houses are made of by cutting steel wall sheets to create openings for doors and windows based on architectural demands and it also replaces original plywood floor. In recent years, insulated, painted and prefabricated doors and windows are being used to fit with containers which makes construction procedure easier but at the same time the architect and designer would have to abide by their recommended dimensions. However, it is finally delivered to the construction site. The whole hightech construction approach using shipping container is considered as a prospective modular structure housing that can save us both money and materials. Shipping containers completely equipped with fixtures and insulation can make this type of construction even easier and speedier (Smith, 2005). Therefore, architects, designers, and homeowners are likely to become more interested in container homes due to its prefabrication aspects and modular properties.

\subsection{Temporary housing}

One of the best applications of shipping container homes is that in the event of natural disasters like flooding, earthquake and bushfire, large numbers of people are in a need of temporary housing (Zhang, Setunge, \& Elmpt, 2014). The approach being used today for post-disaster emergency shelter 
usually includes the use of large communal building such as showgrounds or stadiums in which emergency committees and temporary accommodations in a shape of tent are presented by officials, as happened in the of Hurricane Katrina. While those tents are easy and fast to set up, people affected by the disaster also need residency and facilities set up for a longer period of time.

Usage of altered shipping containers is not still common in post-disaster temporary housing applications. Many experience is available about using shipping containers in housing applications. Also, there are not affordable for application in disaster relief applications as practical. For instance, the Future Shack, idealized by an Australian architect Sean Godsell who was one of the first people that came up with an idea of using shipping container as temporary house, being assembled in 24 hours and having just necessary cuts in the container. The price of one Future Shack built is beyond $\$ 30,000$ which makes it difficult to afford for real post disaster applications. Also, Global Portable Buildings offers disaster recovery temporary housing solutions based on shipping containers (globalportablebuildings.com, 2015) which are again relatively expensive in most of the post-disaster practical applications. Moreover, they are made of brand new shipping containers which questions the reusing notion of those abandoned empty containers stacked in ports all around the world. There are many other design examples in the literature of post-disaster temporary residency regarding shipping containers such as designs for complete villages built of modular units. Study (Pena \& Schuzer, 2012) highlights temporary housing design approaches that aim to utilize shipping containers advantages relating to reusability, strength and portability. In the table 3 you can generally see the suitability for shipping container temporary housing considered in different types of disaster based on the characteristics offered by the U.S Occupational Safety \& Health Administration. 
Table 4. Suitability analysis of shipping container for temporary housing (Zhang, Setunge, \& Elmpt, 2014).

\begin{tabular}{|c|c|c|c|}
\hline Type of Disaster & $\begin{array}{l}\text { Key characteristics (U.S. Occupational } \\
\text { Safety \& Health Administration, 2013) }\end{array}$ & Predicted lead time & $\begin{array}{l}\text { Suitability for shipping } \\
\text { container temporary } \\
\text { housing }\end{array}$ \\
\hline Flooding/Inundation & $\begin{array}{l}\text { Large land areas inaccessible for } \\
\text { long periods, lower destruction than } \\
\text { flash flooding }\end{array}$ & Several days & $\begin{array}{l}\text { Medium - depending on } \\
\text { inundated area }\end{array}$ \\
\hline Flash flooding & Transient, structurally destructive & None & $\begin{array}{l}\text { Medium to Good - } \\
\text { depending on ground } \\
\text { conditions }\end{array}$ \\
\hline Bushfire/grassfire & $\begin{array}{c}\text { Can be structurally destructive. No } \\
\text { significant change to ground } \\
\text { conditions. }\end{array}$ & $\begin{array}{l}\text { Several hours to } \\
\text { several days }\end{array}$ & Good to very good \\
\hline $\begin{array}{l}\text { Earthquake and } \\
\text { landslide }\end{array}$ & $\begin{array}{c}\text { Highly structurally destructive. Can } \\
\text { accompany landslide, fire, flood or } \\
\text { tsunami }\end{array}$ & $\begin{array}{l}\text { None - } \\
\text { depending on } \\
\text { early warning } \\
\text { systems }\end{array}$ & $\begin{array}{c}\text { Medium to Good - } \\
\text { depending on aftershocks }\end{array}$ \\
\hline $\begin{array}{l}\text { Wind storm (incl. } \\
\text { Hurricane, } \\
\text { Tornado) }\end{array}$ & $\begin{array}{l}\text { High displacement of debris, } \\
\text { structurally destructive, sometimes } \\
\text { accompanied by flooding }\end{array}$ & $\begin{array}{l}\text { Several hours to } \\
\text { Several days }\end{array}$ & Good \\
\hline
\end{tabular}

\subsection{Constructability}

In the last 15 years, different projects using shipping containers have emerged in the construction industry. These container buildings range from a single container guesthouse/site-office to a giant 8-container family home to 86-container hotel building. Many engineers believe that shipping containers are in fact just a structural frame, so that home building can adopt prefabricated modular aspects in compliance with the client's demand, architectural plan and engineering request. Fully loaded, it can be stacked eight levels high, and be able to evade corrosion if well coated (Uittenbroek \& Macht, 2009). However, the lack of a comprehensive guidelines merely considering the safe building of container homes is still obvious (Pena \& S.Kurt, 2012). The reason may be due to the recent development with not well-known structural features of shipping container as a home building material. Shipping container is made of corrugated panels (roof and sides), plywood floor, purlins, front doors, frame and rails, which form an integrated structural envelop for a typical home 
construction. In practice, varieties of different construction systems are available. The two types of foundations commonly used in container construction are concrete footing and concrete raft-slab. A raft-slab built beneath the complete area of the building plan where the container is placed over, whereas concrete footings do not cover the entire area. To get additional strength, extra footings are poured in the middle of the areas and admits the corner foundations as the designer demands. Steel reinforcement is commonly being used in those foundations to both compensate temperature differentials in the concrete and the horizontal loads coming from the earth unexcavated area in the case of buried foundation. Thick steel base plates, anchoring to the reinforcement by hooks, are embedded on to the corner footings to secure the structure firmly and resist the uplift movement of the structure due to the lateral load applied. The plywood floors currently used in nearly all shipping containers are treated with different pesticides. An extra physical barrier can also be created by building a subfloor on top of it.

This is not a mandatory step which specifically created if a physical barrier to the treatment chemicals is needed, or to get above some structural remnants of the containers. Plus, subfloor can insulate the internal space of the container with a layer of foam covered by another layer of oriental strand board (OSB). Interestingly, concrete can also be casted on top of the plywood and also it could even be the finished floor with some coloring dyes and patterns added. Although all the shipping containers have the flat roof above them, various roofing system can be executed on its upper level such as shed, hip and gable roof kinds regarding to owners' taste, insulation requirement and expenditure. Many builders believe that the as-built container flat roof is more than necessary for residential roofing. A shed is sloped roof, simple, cheap and easy to erect. A conventional hip and gable rooftops can also be secured atop of the container so quickly. The conventional trussed roof anchored with metal straps is welded to container steel sides. It is to be mentioned that the double roof 
containing of container steel and trussed roof, finally reduces the heat transfer into the building exterior envelope, and holds the consistent temperature much more efficiently. So, adding an additional roofing system in container will obviously cost the builder at the beginning, but at the end definitely save operational and utility energy bills further. It is also to be considered that insulation is usually placed in between metal and trussed roof to try to insulate where the inhomogeneity exists. To make it aesthetically more pleasant, plasterboards are installed to the corrugated roof from bottom surface so the inhabitants would not see bare steel on top of their head. There are many different ways in which we can to insulate shipping container homes appropriately. In North America set of timber frames is usually built up inside or outside of the container to ensure safe paneling and also place insulation materials to improve energy efficiency. Container houses require the least amount of wood in exterior and interior framing because it does not carry any load and they are simply for other purposes than support the main structure. The lightweight cladding (e.g. cedar, vinyl, fiber cement) can be implemented all over the exterior facade, and plasterboard in the interior walls if needed. It also requires some modifications to the ISO Container in order to allow the doors and windows to be installed within them.

These modifications are exactly the same as the traditional home construction systems. It is important to know that insulation on the exterior or interior walls depends on climatic conditions of the region in which the building is placed. It is a common practice that insulating the exterior of the containers is a better choice for cold climate, which provides both conventional exterior envelope aesthetically and serves as insulation property at the same time. In order to provide a thermal break to the ISO container walls, a layer of foil board (e.g. $25 \mathrm{~mm}$ ) is recommended to attach to the walls which is an expanded polystyrene rigid insulating board that has reflective coatings on each side of it. 
Ceramic coating has been widely used for many years by different industry sectors to insulate metal surfaces against humidity, warmth and coldness. Ceramic coating can contribute a lot into energy savings by preventing heat transfer and heat loading onto a structure. The intrinsic feature of ceramic coating is unique. It can be used as paint, adhesive, insulator, fireproofing and acoustic barrier all the same time while involving one aspect of that would not deteriorate its behavior against the other one. Spray of polyurethane foam is proved to collaborate best when it is combined with ceramic insulation paint. With the use of ceramic insulation paint in the exterior and polyurethane foam in the interior, this high performing envelope can contribute to a much smaller carbon footprint than that of conventional structural construction (Fuller, 2006). It was pointed out that both ceramic coating (i.e. supertherm) and polyurethane foam contain special gas in bubbles that gives a high thermal efficiency. The polyurethane foam is available in both open-cell and closed-cell, with differences in cost, density, strength, waterproofing. Because ISO shipping containers might be transferred from one place to another one, closed-cell foam is well suited for its higher strength and durability. The reusable shipping containers with existing floor, wall and roof panels can facilitate custom-fit construction in factory and then be transported to the construction site to reduce the labor mistake and also improve efficiency. In order to have a better quality control, all the preparatory works such as disinfection, cleaning, opening, strengthening, connecting, surface preparation and painting are done in factories. It is worth noting that containers should include all necessary details for the preparation at the factory so that it avoids problems in assembly at construction site. The final changes such as the interior can be finished at construction site. There is an example in Australia of prefabricated modular dwellings with 6 containers having 7 bedrooms. This design comprised of two double storied containers side by side and two single storied modules to the right as living spaces. Hence, a suitable design can be constructed in an assembly line with ease and speed. In Ontario recently people showed more interest into 
container modular construction because of the nice projects which have accomplished around the province from Hamilton to Downtown Toronto.

\subsection{Current status and constraints}

All around the world, over 17 million structurally sound shipping containers are available for reusing after completing their freight applications (michaelbgreen.com.au, 2016). The first reported shipping container house (in two stories) was built in USA in 2006, which proved to be in compliance of the strict guidelines of the UBC-uniform building code. Another example is the Travelodge hotel building constructed at Uxbridge, London. Total of 120 bedrooms by modification of 86 shipping containers onsite (inhabitat.com, 2014). The contractor believes this modular construction was 40$60 \%$ quicker and even produced $30 \%$ onsite waste of the amount produced for conventional building. Also, it does not need complicated construction method which helps to cut down cost drastically. In another project a Dutch developer converts shipping containers into 1000 units of student housing in Amsterdam (Uittenbroek \& Macht, 2009). It was stacked up to five levels high, connected with bolts together and divided into 12 separate buildings. In different development, four shipping containers were retrofitted into a children's activity center in South Melbourne, Australia. The forms and aesthetics were generated by sustainable prospect with respect to creating a low-cost and zero waste construction (inhabitat.com, 2014). It is well known that shipping containers are flexible in construction system due to its modular feature and rigidity. However, it is still up to the constructability method used and country's standard practices to comply with local rules and regulations. As a prefabricated modular structure, building of container homes has a considerable degree of constructability potential. Although there is adjustment in construction procedure, the amount of container homes is still relatively low globally compared to what is expected due to lack of skilled labor to handle new materials and methods (Fuller, 2006). This study also determines another barrier 
in development of container homes construction which is the effect of their appearance on owners' choice due to their metal wrapping which mostly reminds them as a means of freight and does not picture the comfort of home into their mind. On the other hand, salvaging of the shipping containers can contribute to carbon footprint emission substantially. It is also important to consider some features that control heat loss and gain and insulation to provide a comfortable living. The study (Brandt, 2011) mentions that the disadvantage of a shipping container is its temperature, such that in summer the container has extremely high temperatures while in winter the container experiences low temperatures around its exterior envelope. The entity of such design should be in accordance to the site climatic conditions.

\subsection{Sustainability and carbon footprint}

Mostly, current literature on reuse of shipping containers mainly focuses on its different aspects and design aspects. Almost no published paper has addressed the life cycle assessment of this construction and its sustainability potential so the huge research gap exists in this aspect. Reuse of shipping containers for house design and construction is a smart approach to improve sustainability around the country against the typical conventional construction. A container home can be erected utilizing 75\% recycled materials by weight as mentioned by the study (Martinez-Garcia, 2014). Building container homes is sustainable because of the ways the solid structure converted into a repurposed entity. These days, it is forging into an eco-friendly construction due to recent improvement of some features like wallboard or paneling with insulation, well-insulated flooring or ceiling options, ceramic coating and polyurethane foam insulation, low VOC paints, primers, adhesives and sealants. These eco-friendly features make the container building even more energyefficient and sustainable in a way that nobody has experienced it. Also, shipping containers are well produced, which is fire, rust and mold-resistant. It also saves the labor cost and fuel needed to transfer 
them back to their country of origin. Container steel is not a decomposing material to turn into compost in landfill and recycling requires melting of shipping container by using basic oxygen furnace (BOF) and electric arc furnace (EAF), which consumes considerable amount of energy and emits greenhouse gases to get rid of it. For instance, $3.63 \mathrm{t}$ shipping container needs $8000 \mathrm{kWh}$ of electrical energy to make them into steel blocks which is a huge amount of energy and subsequently money. While the process of reusing that entire $3.63 \mathrm{t}$ of shipping container into a home building takes only $400 \mathrm{kWh}$ of energy, only 5\% of the energy required to melt it back to steel blocks. It is also proved that hat each ton of steel making emissions almost $2 \mathrm{t}$ of $\mathrm{CO} 2$ and $40 \mathrm{~kg}$ of other gaseous emission into the atmosphere (Islam, Zhang, Setunge, \& Bhuiyan, 2016). Having assessed, carbon footprints and other environmental impacts of a container building over its life span is a complex exercise. It requires evaluation of all its products, processes and services over whole life cycle stages. Construction and maintenance phases are comprised of products, process and services of assembled building elements. Operational phase has heating and cooling demands, which has enormous environmental impact. Final disposal has hazardous land filling an incineration that may also have considerable impact to environment. The definition of sustainable building relies on green building to both include reducing its environmental impacts and also creating healthy environment for occupants. So, the main emphasis is to choose materials that are free from harmful chemicals as well as excessive environmental impacts. Prefabricated container homes might offer a number of unique opportunities to satisfy all those mentioned targets. An architectural company (Lendager Architects) claimed that they cut down the carbon emissions evaluating their project which was built in Denmark using shipping containers. The house was built with two shipping containers, where the floor, wall, roof and facade were made of different recycled and upcycled (i.e. reused with minimal modification for another purpose) materials. When the house was evaluated using LCA approach, a reduction of $86 \%$ CO2emission was obtained compared to a comparable conventional. 


\subsection{Shipping container building documents}

Published information on shipping containers used for non-shipping applications is not common, and published data needed for structural modeling and analysis of shipping containers is even more difficult to access. Many of the available references do not argue the structural strength and response of shipping containers under abnormal loading scenarios or modifications. There are several books like (Kotnik, 2008)where interesting building projects using shipping containers are presented. However, additional strengthening elements is provided to the containers in most cases, because the container's structural strength is unknown when modified.

Although aesthetics is important for architects and designers, shipping containers cannot be viewed as building blocks if efficiency and economics are driving the project. The projects described in (Kotnik, 2008)and other architecturally driven container building books are not significant to the structural aspects that we need and they typically do not take into account structural considerations. Borvik et al. (Borvik, Burbach, Langberg, \& Langseth, 2008) performed some blast load structural tests on actual ISO containers. The available information is relevant and important to structurally define and evaluate performance of shipping containers. However, we do not consider blast loading scenarios. These documents are likely the only information publicly available involving modifications and testing of full scale shipping containers. In the following you can see how different codes globally encompass their design and consideration.

\subsubsection{Canadian Standards Association (CSA)}

Currently, the CSA does not disclose any specific guidelines for designing of ISO Shipping container houses as it is a recently growing topic in Canada and more researches need to be done to prove its application safely in residential and temporary housing project. Once more research is 
conducted in this field using the Canadian Code, new prospective or design approaches can be formed to withstand the load applied, design ratio and its constructability in future design. In the case study, we used the ordinary load combinations applied to the buildings proposed by NBCC 2015 and the design guideline according to CSA S16-09 were performed to verify the strength of the in-built elements. The table 4 below shows the NBCC 2015 proposed load combinations.

Table 5. Load combinations for ultimate limit state by NBCC 2015

\begin{tabular}{ccc}
\hline Case & Principal Loads & Companion Loads \\
\hline $\mathbf{1}$ & $1.4 \mathrm{D}$ & - \\
\hline $\mathbf{2}$ & $(1.25 \mathrm{D}$ or $0.9 \mathrm{D})+1.5 \mathrm{~L}$ & $0.5 \mathrm{~S}$ or $0.4 \mathrm{~W}$ \\
\hline $\mathbf{3}$ & $(1.25 \mathrm{D}$ or $0.9 \mathrm{D})+1.5 \mathrm{~S}$ & $0.5 \mathrm{~L}$ or $0.4 \mathrm{~W}$ \\
\hline $\mathbf{4}$ & $(1.25 \mathrm{D}$ or $0.9 \mathrm{D})+1.4 \mathrm{~W}$ & $0.5 \mathrm{~L}$ or $0.4 \mathrm{~S}$ \\
\hline $\mathbf{5}$ & $1.0 \mathrm{D}+1.0 \mathrm{E}$ & $0.5 \mathrm{~L}+0.25 \mathrm{~S}$ \\
\hline
\end{tabular}

In which:

D: Dead load

L: Live load

S: Snow load

W: Wind load

E: Earthquake load

\subsubsection{ISO \& CSC standards}

The International Organization for Standardization (ISO) and the International Convention for Safe Containers (CSC) offers documents which dictate shipping containers' specifications, structural strengths, serviceability, and applications. Almost all globally used shipping container conforms to current standards of shipping container manufacturer data, and ISO container standards of 668 (ISO668, 1995), 830 (ISO830, 1999), 6346 (ISO6346, 1995), 1496-1 (ISO1496-1, 1990), 1161 (ISO1161, 1990), 2308 (ISO2308, 1972), and 3874 (ISO3874, 1997). These container standards encompass every specification for shipping containers including structural limits. The structural limitations of an ISO shipping container are discussed in ISO 1496-1 (ISO1496-1, 1990). ISO 1496-1 describes a series of structural tests all ISO containers must pass in order to be in operation, and the required tests are the only source of information regarding the container's structural strength characteristics. Figure 3 presents examples of the structural load test from ISO 1496-1 (ISO1496-1, 
1990). This standard carried different tests to evaluate the container strength and their response was determined subsequently. They considered 4 tests, each situation is shown in Figure 3. For example, in the second test they simultaneously applied $942 \mathrm{kN}$ on the top corner castings and $135 \mathrm{kN}$ in the bottom corner casting and measured the deflection corresponding to that to validate the structural integrity of ISO container. Also, in the Table 4, some characteristics discussed in each of the ISO shipping container Standard are shown.

Table 6. ISO container characteristics provided in ISO standards

\begin{tabular}{|c|c|}
\hline Standard & Information provided \\
\hline $\begin{array}{l}\text { BS ISO 9897:1997 Freight } \\
\text { Containers }\end{array}$ & $\begin{array}{l}\text { Container Equipment Data } \\
\text { Exchange (CEDEX)- General } \\
\text { Communication Board }\end{array}$ \\
\hline $\begin{array}{c}\text { BS ISO } 830: 1999 \text { Freight } \\
\text { Containers }\end{array}$ & Vocabulary \\
\hline $\begin{array}{l}\text { BS ISO 8323:1985 Freight } \\
\text { Containers }\end{array}$ & $\begin{array}{l}\text { Air/Surface(intermodal) general } \\
\text { purpose containers-specifications } \\
\text { and tests }\end{array}$ \\
\hline $\begin{array}{l}\text { BS ISO 3784:1997 Series } 1 \\
\text { freight containers }\end{array}$ & $\begin{array}{l}\text { Classification, dimensions and } \\
\text { ratings }\end{array}$ \\
\hline $\begin{array}{c}\text { ISO 1496-1:1990 Freight } \\
\text { Containers }\end{array}$ & $\begin{array}{l}\text { specifications and testing of series } \\
1 \text { freight containers- }\end{array}$ \\
\hline
\end{tabular}

\begin{tabular}{|c|c|c|c|c|c|c|c|}
\hline \begin{tabular}{|c|}
$\begin{array}{c}942 \mathrm{kN} \\
(212 \mathrm{kips})\end{array}$ \\
\end{tabular} & $\begin{array}{l}\text { FOR EACH ARROW ACTING ON } \\
\text { TOP CORNER FITINGS }\end{array}$ & \begin{tabular}{|c}
$942 \mathrm{kN}$ \\
$(212 \mathrm{kips})$
\end{tabular} & $\begin{array}{l}\text { FOR EACH ARROW ACTING ON } \\
\text { TOP CORNER FIITINGS }\end{array}$ & $150 \mathrm{kN}$ & FOR EACH ARROW & $75 \mathrm{kN}$ & FOR EACH ARROW \\
\hline \begin{tabular}{|l}
$135 \mathrm{kN}$ \\
$(30 \mathrm{kips})$
\end{tabular} & $\begin{array}{l}\text { FOR EACH ARROW ACTING ON } \\
\text { BOTTOM CORNER FITINGS }\end{array}$ & \begin{tabular}{|l}
$135 \mathrm{kN}$ \\
$(30 \mathrm{kips})$
\end{tabular} & $\begin{array}{l}\text { FOR EACH ARROW ACTING ON } \\
\text { BOTIOM CORNER FITINGS }\end{array}$ & & & & \\
\hline
\end{tabular}

Figure 3. Example of structural tests by ISO 1496-1 (ISO1496-1, 1990) 


\section{Evaluation, modeling, and analysis}

\subsection{Introduction}

Many shipping containers used for non-freight purposes are modified from their original design, and specifications for safely using these containers for building applications is lacking. Shipping containers have different practical applications such as post-disaster residency or military operations and housing and are economical, durable, fast to erect and transportable. The shipping container's structural integrity, modification properties, foundation requirements, building code regulations, and reinforcing limits are mostly unknown. In the table 5 you can see the load capacity characteristics of two types of HC shipping container. Noted that, load capacity it defined as the amount of loads which can be loaded into the container based on the regular loading practice used in freight industry without jeopardizing the container strength integrity. Also, surface load capacity term used in table 5, is the maximum amount of load which can be tolerated on each square meter of floor.

Table 7. Load capacity characteristics of shipping containers.

\begin{tabular}{ccccc}
\hline Model & Self-weight (kg) & $\begin{array}{c}\text { Total load Capacity } \\
(\mathbf{k g})\end{array}$ & $\begin{array}{c}\text { Surface load Capacity } \\
(\mathbf{K g} / \mathbf{m} 2)\end{array}$ & $\begin{array}{c}\text { Capacity volume } \\
(\mathbf{m} 3)\end{array}$ \\
\hline 20'HC-6.0 m long & 2300 & 28000 & 867.63 & 37.4 \\
\hline 40'HC-12 m long & 4500 & 36000 & 1229.51 & 76.1 \\
\hline
\end{tabular}

According to (Giriunas, Sezen, \& Dupaix, 2015), the finite element analysis demonstrates how both modified and unmodified 20' container models respond under five given loading scenarios. They considered 8 modification model to see which one is more susceptible to the assumed loading scenario. In Figure 4 and 5, you can see the modification models and loading scenarios, respectively. 


\begin{tabular}{|c|c|c|c|}
\hline M1 & M2 & M3 & M4 \\
\hline & Mr & & \\
\hline & & & \\
\hline
\end{tabular}

Figure 4. 20’ ISO shipping containers modification models (Giriunas, Sezen, \& Dupaix, 2015).

\begin{tabular}{|c|c|c|c|c|}
\hline $\begin{array}{c}\text { Loading } \\
\text { Scenario 1 }\end{array}$ & $\begin{array}{c}\text { Loading } \\
\text { Scenario 2 }\end{array}$ & $\begin{array}{c}\text { Loading } \\
\text { Scenario 3 }\end{array}$ & $\begin{array}{c}\text { Loading } \\
\text { Scenario 4 }\end{array}$ & $\begin{array}{c}\text { Loading } \\
\text { Scenario 5 }\end{array}$ \\
\hline $\begin{array}{c}\text { Compressive Point } \\
\text { Loading } \\
\text { (4 corner fittings })\end{array}$ & $\begin{array}{c}\text { Compressive Point } \\
\text { Loading } \\
(2 \text { corner fittings } \\
\text { short side })\end{array}$ & $\begin{array}{c}\text { Compressive Point } \\
\text { Loading } \\
\text { (2 corner fittings } \\
\text { long side })\end{array}$ & $\begin{array}{c}\text { Transverse Point } \\
\text { Loading (Inward })\end{array}$ & $\begin{array}{c}\text { Longitudinal Point } \\
\text { Loading } \\
\text { (Inward })\end{array}$ \\
\hline
\end{tabular}

Figure 5. 20' loading scenarios simulated on shipping container models (Giriunas, Sezen, \& Dupaix, 2015).

The loading scenarios incorporate the effect of gravity and lateral loading, and the computer simulations demonstrate the effectiveness of the container walls and roof to resist the loads. Having used the computer programs SolidWorks, Hypermesh, and Abaqus, the following conclusions have been drawn. 
- For all loading scenarios, the calculated maximum elastic load for the complete model (M1) reached or exceeded the corresponding loads specified in ISO 1496-1 (Giriunas, Sezen, \& Dupaix, 2015). With the exception of the roof removed model (M4) in Loading Scenario 5, the maximum resisting load for almost all the modified containers was either close or less than the ISO 1496-1 (Giriunas, Sezen, \& Dupaix, 2015) specified loads. Therefore, it is likely that yielding may occur in modified containers before reaching the capacity required in ISO 14961 (Giriunas, Sezen, \& Dupaix, 2015). As long as the container structure stacks the containers similar to transportation methods, the ISO loading scenarios should applicable.

- For axial/vertical loads applied on the top corner fittings, end walls were generally the strongest load resisting components, the sidewalls were the next strongest load resisting components, and the roof typically did not have any structural contribution.

- When subjected to the vertical point loads from Loading Scenarios 2 and 3, the original container model M1 had lower maximum applied forces compared to the other container models. When all four walls were present in the container model (M1 and M4), a localized yield stress in the door header may have occurred resulting in a reduced maximum applied force compared to the other container models.

- For transverse lateral loads applied on the top corner fittings, the end walls were the strongest load resisting components. For longitudinal lateral loads applied on the top corner fittings, the sidewalls were the strongest load resisting components. The roof generally did not have any structural contribution for lateral loads. The results from models M2 and M3 for Loading Scenarios 4 and 5 indicate that a transverse end wall can resist $4.2 \mathrm{kip} / \mathrm{ft}$ lateral load at yielding (two $2438 \mathrm{~mm}$ long walls carry $149.2 \mathrm{kN}$ each, while a longitudinal end wall can resist 0.85 kip/ft lateral load at yielding (two $6058 \mathrm{~mm}$ long walls carry $75 \mathrm{kN}$ each. 
- Original container model (M1) is the strongest for all loading scenarios because all components are in place to resist applied loads. The model with no walls (M8) was the weakest in all cases. Figures 6 to 11 elaborate the structural elements in the $40^{\prime} \mathrm{HC}$ container such as floor, door face, lateral face and roof.

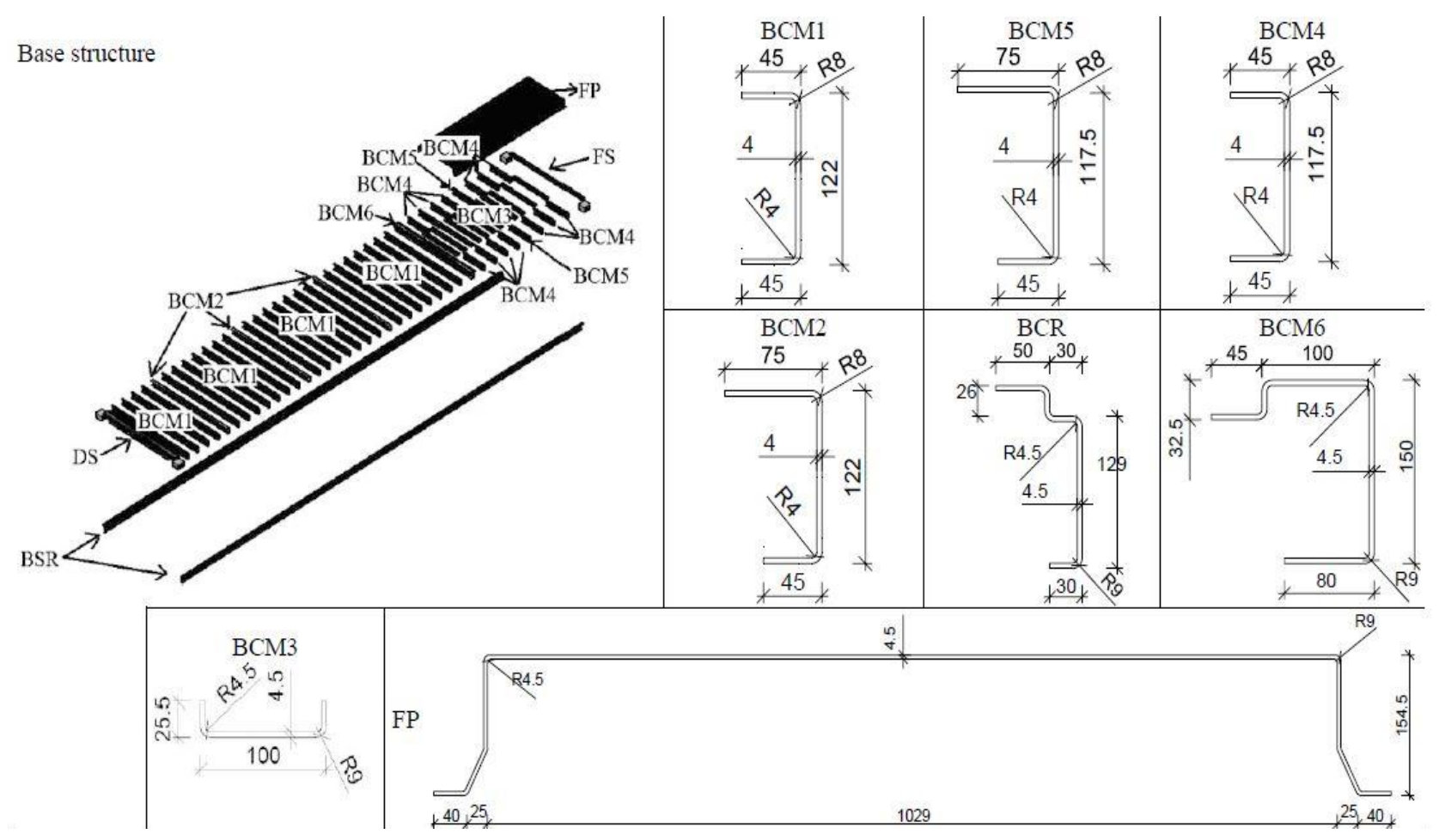

Figure 6. Floor structural details of 40' container.

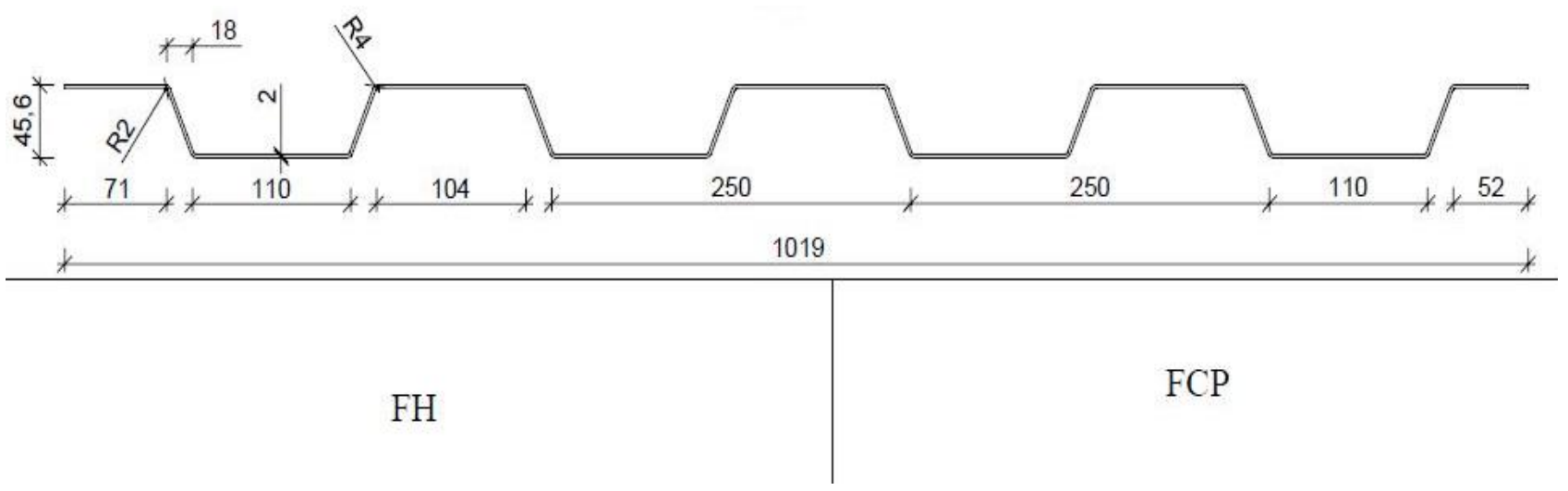

Figure 7. Front face structural details of 40' container consists of FH and FCP elements. 

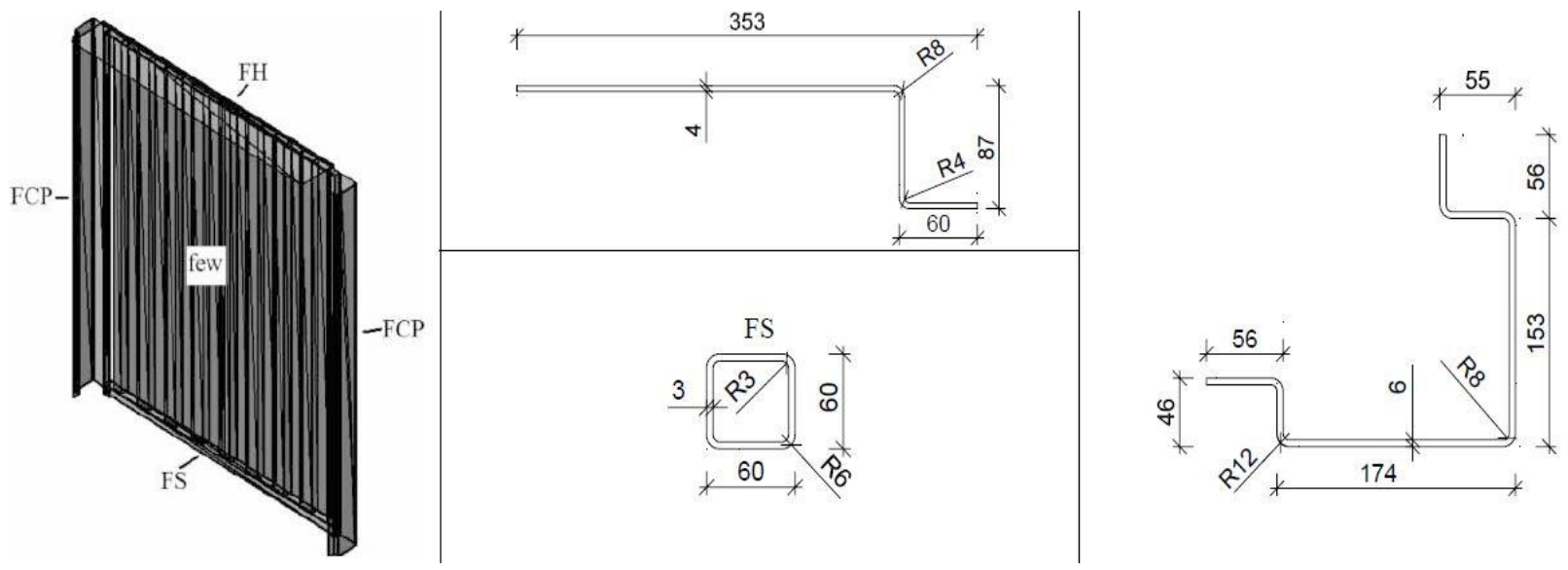

Figure 8. FCP and FH definition in Figure 7.
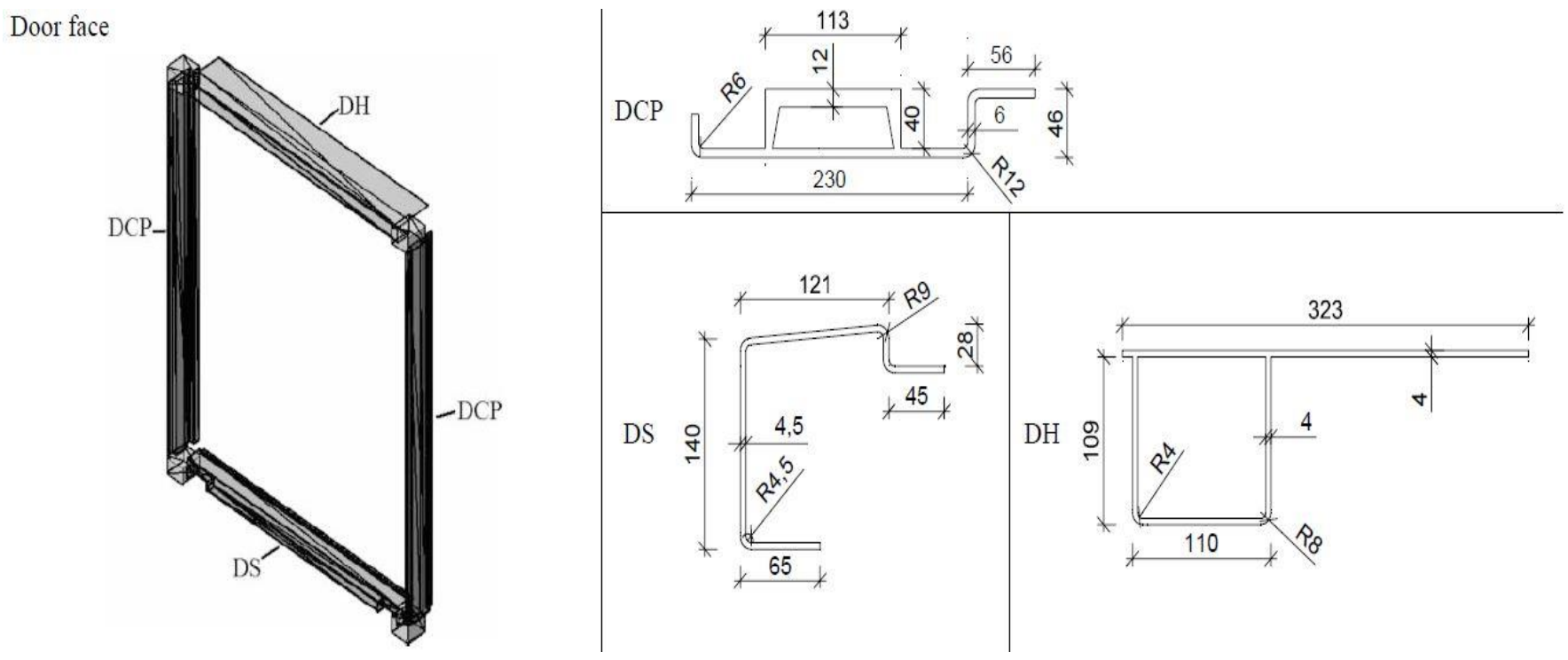

Figure 9. Door face structural details of 40' container. 


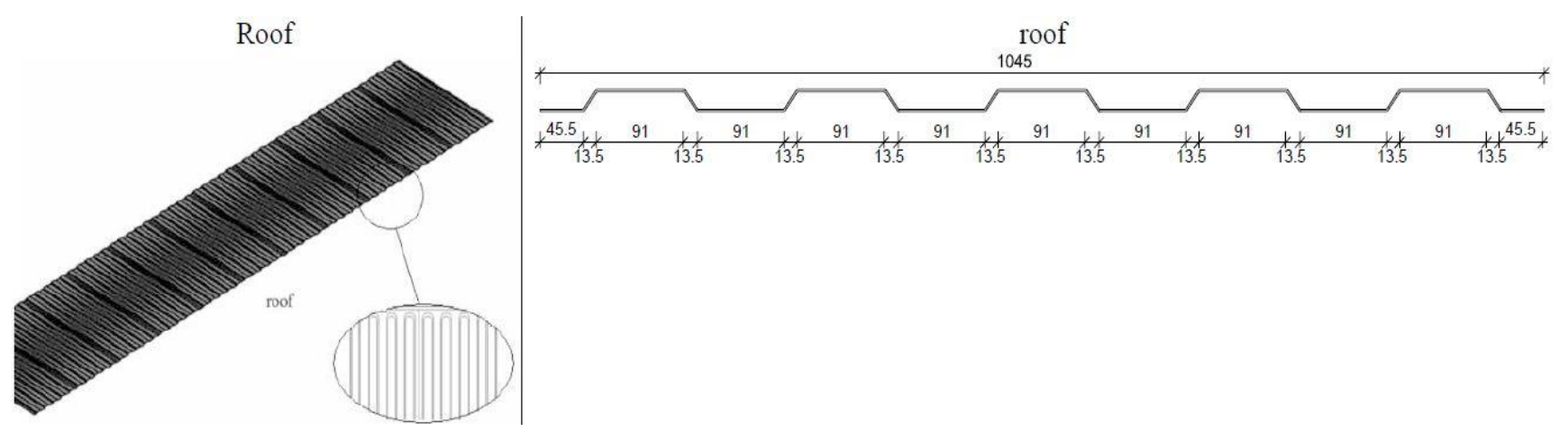

Figure 10. Roof face structural elements of 40' container.

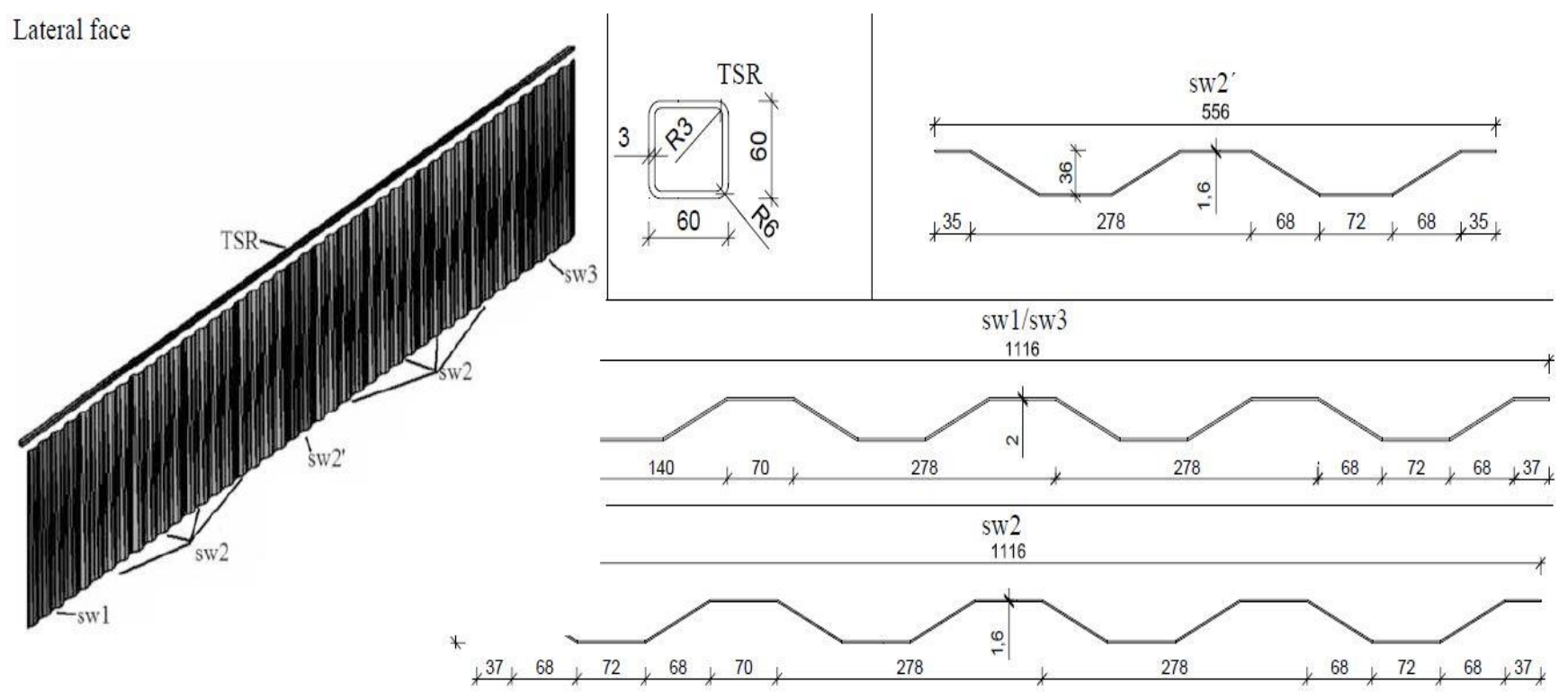

Figure 11. Lateral face structural elements of 40' Container. 


\subsection{Structural consideration}

\subsubsection{Foundations}

Spread footings, mat foundations and piles are three types of foundation recommended for

shipping container structures practically used by the designers. Spread footings are a reinforced concrete enlargement at the bottom of a column in a structure. Spread footings are ideal for small to medium size structures with moderate to good soil conditions, are economical, easy to build, and the shape and size is a designer choice. Mat foundations are enlarged spread footings which is spread all beneath the structure. Mats are used when spread footings would cover more than 50\% of the building footprint, when unpredictable settlements may be a potential and if uplift forces are too large for regular spread footings or if the ground water table is above the footing. Piles are long columns made of concrete, steel, or timber, and can be built well over $20 \mathrm{ft}$ into the soil. Piles (deep foundations) are used when the surface soils are too weak to build on, the spread footing area exceeds one-third the building's footprint, the soils are subject to scour and potential flooding, large uplift or lateral load capacity is needed and even in a case that the soil structure is complex. Piles also could be used in soft soils or prospect flood areas to elevate the container structures and provide structural stability.

Practically, most of the structures created from shipping containers will use either concrete spread footings or a mat foundation as an appropriate foundation system. Especially under low gravity loads, concrete masonry blocks and bricks potentially can be used for foundations as shown in Figure 12. Other foundations for container structures include wood beam footings, weld-on jack stands, concrete masonry units (cinder blocks), and helical piles. 


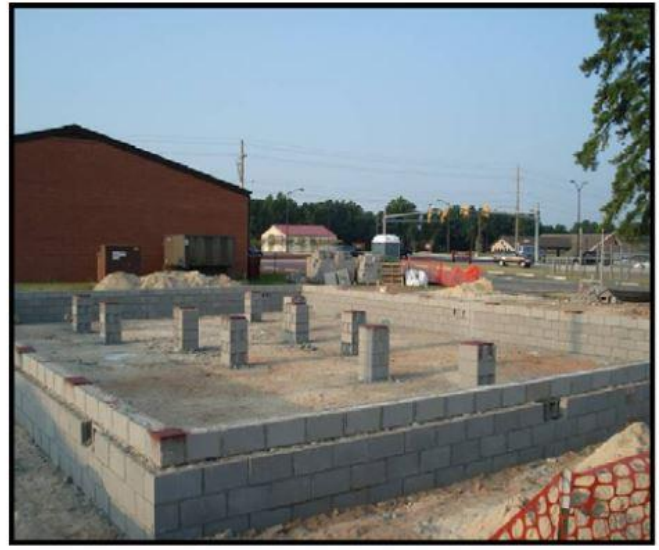

(a)

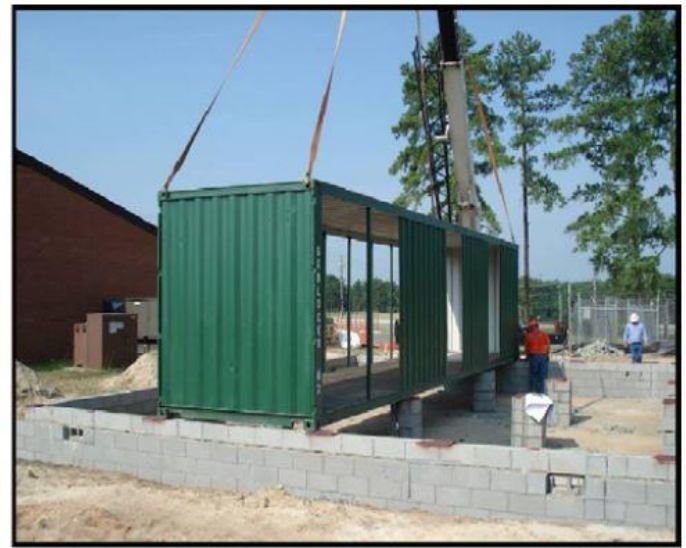

(b)

Figure 12. (a) Concrete block foundation, (b) modified container on block foundation (Giriunas, Sezen, \& Dupaix, 2015).

\subsubsection{Connections}

A common connection method attaches a container to an appropriately designed steel base plate with welds as shown in Fig. 13a. this type of connection would not be that much resistant in case of uplift so the structural engineer is to consider different approach to strengthen the whole structure against uplift force. The underside of the base plate has reinforcing bars (anchor bolts) of varying lengths. The anchor bolts are welded onto the underside of the plate and are cast into the concrete foundations or grout while it is still wet. Once the concrete or grout is hardened, the base plate is anchored into the foundations. there are multiple options for connecting containers to other containers or transporting devices presented in ISO 3874 (ISO3874, 1997). The connection devices lock the containers together by attaching through the top or bottom openings on corner fittings. Twist locks and latch-locks are connection devices securing two containers at the corner fittings during stacking, transporting, or lifting empty container situations. Stacking fittings or stacking cones secure containers only horizontally during stacking or transporting and are always used in junction with other securing devices. The connection devices can support lateral and gravity loads only under normal shipping 
operations (150 kN tensile strength and $850 \mathrm{kN}$ compressive strength). Depending on the container structure's application, further modification to the locking connections may need to be considered. Figure 13.b shows a non-locking connection method between two containers used for a structure which is uncommon, and its structural characteristics are unknown.

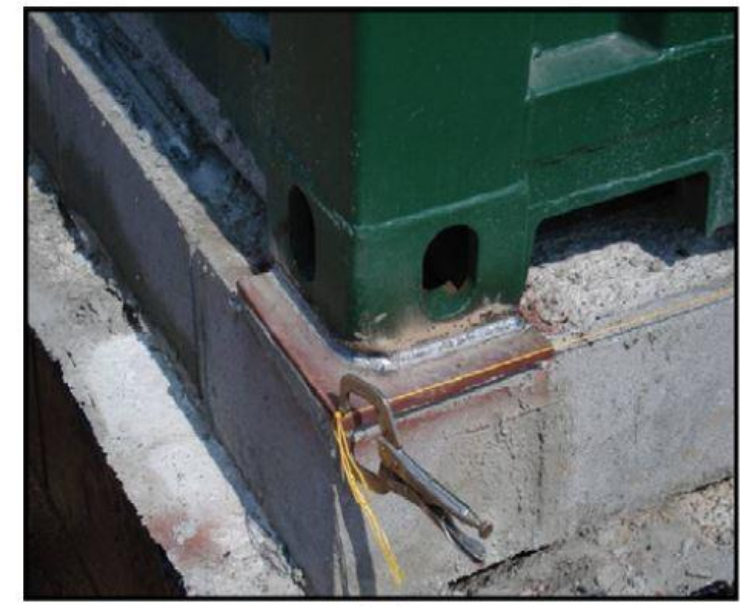

(a)

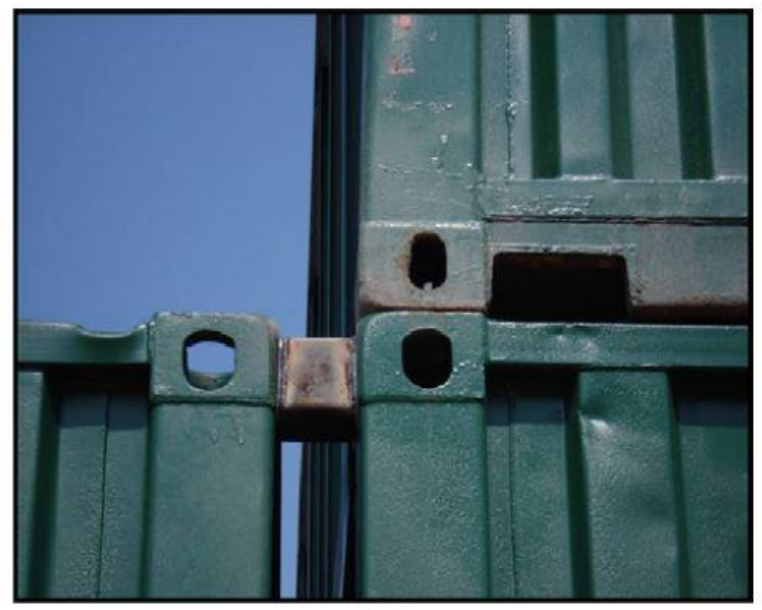

(b)

Figure 13. (a) Welded shipping container to base plate, (b) uncommon connection between shipping containers (Giriunas, Sezen, \& Dupaix, 2015). 


\subsection{Case Study}

\subsubsection{Introduction and Scope}

A two story ISO container house for residential usage in Ontario was chosen. Six containers connected together by the means of bolts and welding sitting of a $30 \mathrm{MPa}$ concrete 12 " thick wall footing which provides the crawlspace for maintenance and services, provide $1600 \mathrm{SF}$ of residential space as the proposed plan demonstrates in Figure 14 and 15. Each container is comprised of both structure and envelope.

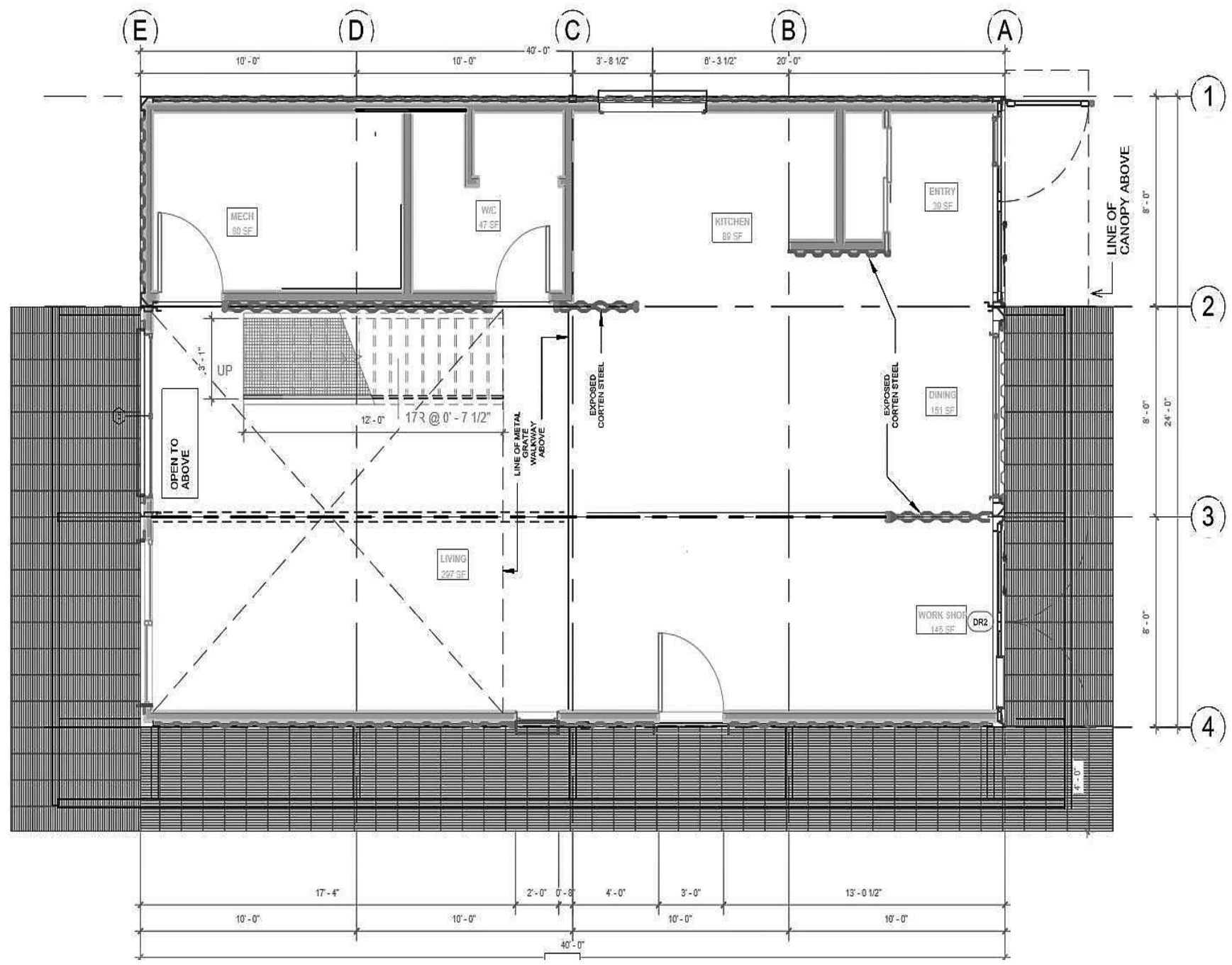

Figure 14. First floor architectural plan. 


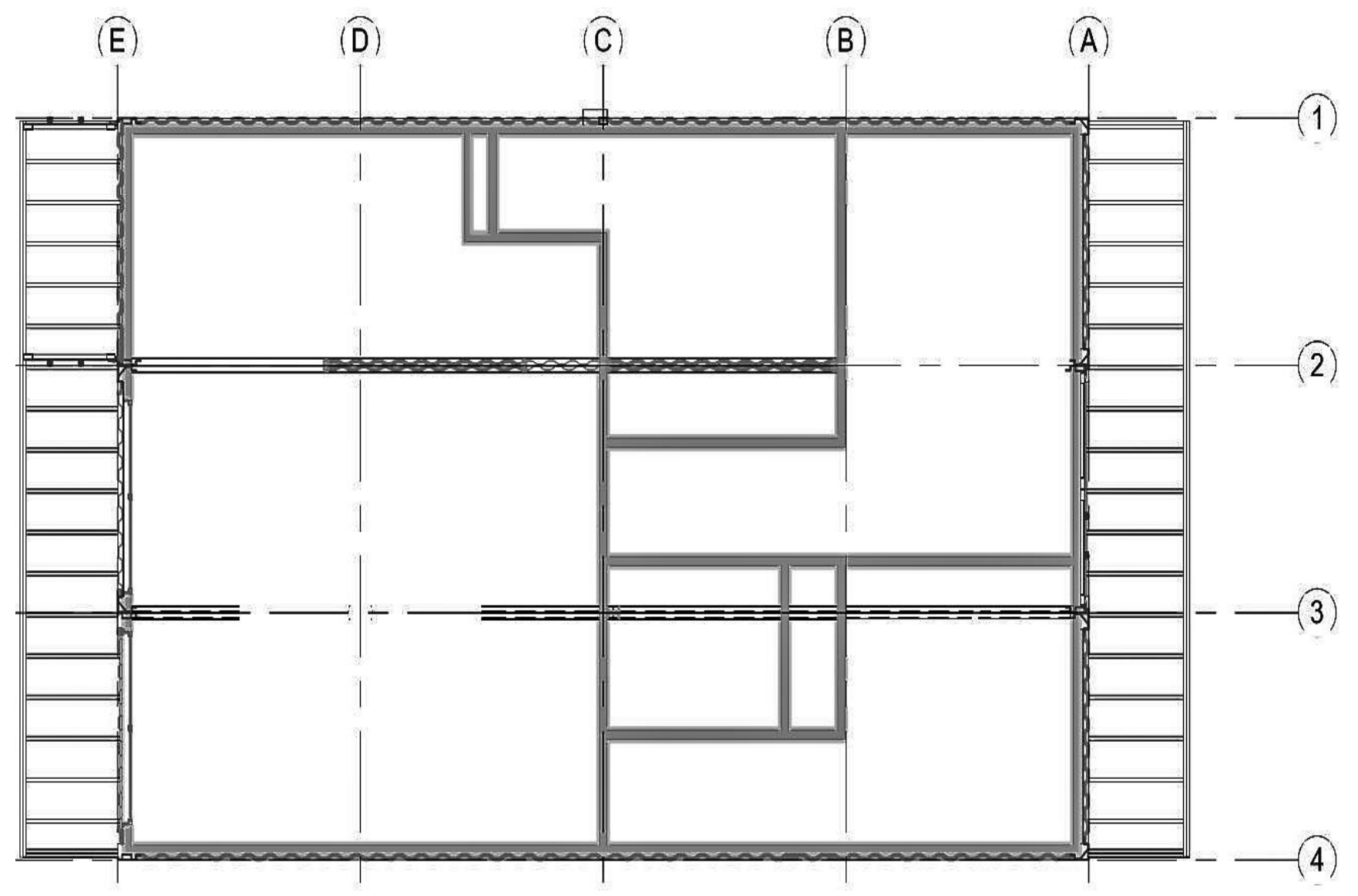

Figure 15. Second floor architectural plan.

In addition, all cut out openings are reinforced with engineered steel HSS, Angle and Channels sized in accordance to the Ontario engineering standards. Interior wall composition includes $2 * 4$ and $2 * 6$ timber frame construction throughout. Roof is framed with $2 * 8$ timber wood with minimum slope engineered for all required loads, including local snow as well as for green roof tiles and solar PV panels. Figure 16 depicts the graphical view of the building. 


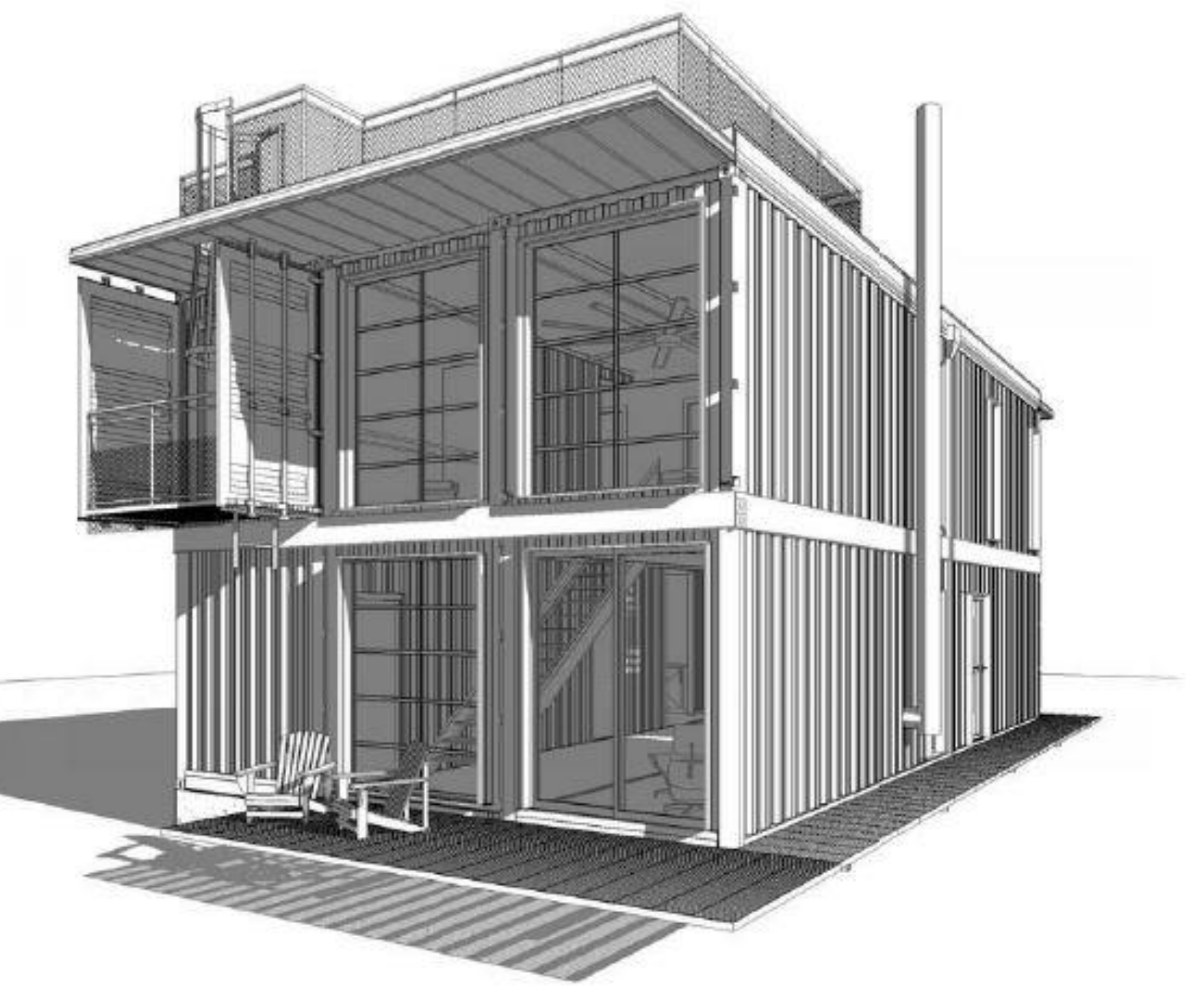

Figure 16. Façade of single family dwelling (1600SF). 


\subsubsection{Loading}

International Standard ISO 1496-1 stipulates the static and dynamic design load for the ISO containers mandatory under which the ISO container are designed. When loaded to its maximum gross weight, the container must be strong enough to tolerate the $2 \mathrm{~g}$ loading downward, $0.6 \mathrm{~g}$ lateral and $2 \mathrm{~g}$ longitudinal. Moreover, they are to withstand eight similar containers fully loaded and stacked on top of them. So they have a very strong intrinsic characteristic despite their light weight. In one test the 1496-1 standard applies the $660 \mathrm{lbs}$ on the area of 2' by 1' in the weakest part of the roof which is usually the center of the container. The floor is to stand the design test of 16 kips on the foot print of 44 sq. inches. Also the floor has to be able to carry the load of as twice its rated payload capacity which is $47895 \mathrm{lbs}$ for a $20^{\prime}$ container and $58823 \mathrm{lbs}$ for a $40^{\prime}$ container in an evenly distributed situation.

Approximately, the floor area which is available to loading is 320 sq. feet with the maximum pressure of $183 \mathrm{psf}$. The end walls and side walls are to be able to carry the $0.4 \mathrm{p}$ and $0.6 \mathrm{p}$ respectively which corresponds to the amount of 23.5 and $35.3 \mathrm{kips}$ for $40^{\prime}$ containers. The side walls have to stand the pressure of $110 \mathrm{psf}$ with the roughly 320 sq. feet contact area. In the following table all the design loads and the coefficients related to them are tabulated. While the structure is assumed to be at Hamilton, the Soil design allowable bearing pressure is assumed to be $125 \mathrm{kPa}$ (SLS) and also the site Class is assumed to be Class D. Table 7 discusses the design loads chosen for the project separately. 
Table 8. Design loads

\begin{tabular}{|c|c|c|}
\hline DEAD LOAD & Superimposed Roof Loads+Self Load & \\
\hline & Roof membrane & $=0.30 \mathrm{kPa}$ \\
\hline & Insulation & $=0.05 \mathrm{kPa}$ \\
\hline & Joists & $=0.15 \mathrm{kPa}$ \\
\hline & Ceiling & $=0.20 \mathrm{Kpa}$ \\
\hline & Mechanical allowance & $=0.05 \mathrm{kPa}$ \\
\hline TOTAL DEAD LOAD & & $0.75 \mathrm{kPa}$ \\
\hline \multirow[t]{2}{*}{ LIVE LOAD } & Main Floor & $=2.4 \mathrm{kPa}$ \\
\hline & Roof & $=1.0 \mathrm{Kpa}$ \\
\hline \multirow[t]{9}{*}{ SNOW LOAD } & $\mathrm{S}=I_{S}\left[S_{S} C_{b} C_{w} C_{s} C_{a}+S_{r}\right]$ & (Hamilton, ON) \\
\hline & $S_{s}=1.1 \mathrm{kPa}$ & \\
\hline & $S_{r}=0.4 \mathrm{kPa}$ & \\
\hline & $I_{S}=1.00(U L S), 0.9(S L S)$ & \\
\hline & $C_{b}=0.8$ & \\
\hline & $C_{w}=1.0$ & \\
\hline & $C_{s}=1.0$ & \\
\hline & $C_{a}=1.0$ & (Unless otherwise mentioned) \\
\hline & $\mathrm{S}=1.28 \mathrm{kPa}$ & (Basis snow load) \\
\hline \multirow[t]{6}{*}{ WIND LOAD } & $P=I_{w} q C_{e} C_{p} C_{g}$ & (Hamilton, ON) \\
\hline & $q_{50}=0.46 \mathrm{kPa}$ & \\
\hline & $C_{e}=0.92$ & \\
\hline & $C_{p} C_{g}=0.5,-2$ & (Unless otherwise mentioned) \\
\hline & $P$ downforce $=0.48 \mathrm{kPa}$ & \\
\hline & P uplift $=-0.84 \mathrm{kPa}$ & \\
\hline \multirow[t]{7}{*}{ SEISMIC LOAD } & $\mathrm{V}=\mathrm{S}(\mathrm{TA}) M_{v} I_{E} W / R_{b} R_{o}$ & (Hamilton, ON) \\
\hline & $S A(0.2)=0.26$ & $I_{E}=1$ \\
\hline & $\mathrm{SA}(0.5)=0.128$ & $M_{v}=1$ \\
\hline & $S A(1.0)=0.061$ & $\mathrm{TA}=0.2 \mathrm{~s}$ \\
\hline & $\mathrm{SA}(2.0)=0.28$ & $R_{d}=1.5$ \\
\hline & $P G A=0.168$ & $R_{d}=1.5$ \\
\hline & W=Dead $+25 \%$ Basic Snow \& 50\% Live & \\
\hline
\end{tabular}

In which:

Ductility Modifier, $\mathrm{R}_{\mathrm{d}}$ [NBCC Table 4.1.8.9]

Overstrength Modifier, $\mathrm{R}_{\mathrm{o}}$ [NBCC Table 4.1.8.9] 
Higher Mode Factor, $\mathrm{M}_{\mathrm{v}}$ [NBCC Table 4.1.8.11]

Importance Factor, IE [NBCC Table 4.1.8.5]

\subsubsection{Load Capacities:}

Critical Load Combination: 1.25 D+1.5 S+0.4 W

Dead Load $=0.75 \mathrm{kPa}$

Snow Load $=1.28 \mathrm{kPa}($ Basic Snow Load), 3.6kPa (Accumulated Snow)

Wind Load $=0.48 \mathrm{kPa}$ (Downforce)

Corresponding Design Load $3.05 \mathrm{kPa}$ (With Basic Snow Load)

Corresponding Design Load = 6.5 kPa (With Accumulated Snow Load)

Container Roof Capacity is 165 psf (approximately) which is $7.9 \mathrm{kPa}>6.5 \mathrm{kPa} \quad$ O.K

For the floor capacity we have:

Maximum Load Combination: 1.25 DL + 1.5 LL

Dead Load $=0.75 \mathrm{kPa}$

Live Load $=2.4 \mathrm{kPa}$

Maximum Design Load $=4.5 \mathrm{kPa}$

Container Floor Capacity is 180 psf (conservatively) which is $8.6 \mathrm{kPa}>4.5 \mathrm{kPa}$

O.K

Similarly, for the wall capacities we have:

Wind Load $=0.84 \mathrm{kPa}$

Container Wall Lateral Capacity is $110 \mathrm{psf}$ (conservatively) which is $5.3 \mathrm{kPa}>0.84 \mathrm{kPa}$

O.K 


\subsubsection{Analysis and design}

Analysis process were performed with ETABS version 17 while all the spacings and measurements were conducted according to the architectural drawings proposed as Figure 14 and 15 show. The structure was analyzed according to NBCC 2015 Load combinations regarding all loading possible scenarios. 3D view of the model is provided in the Figure 17.

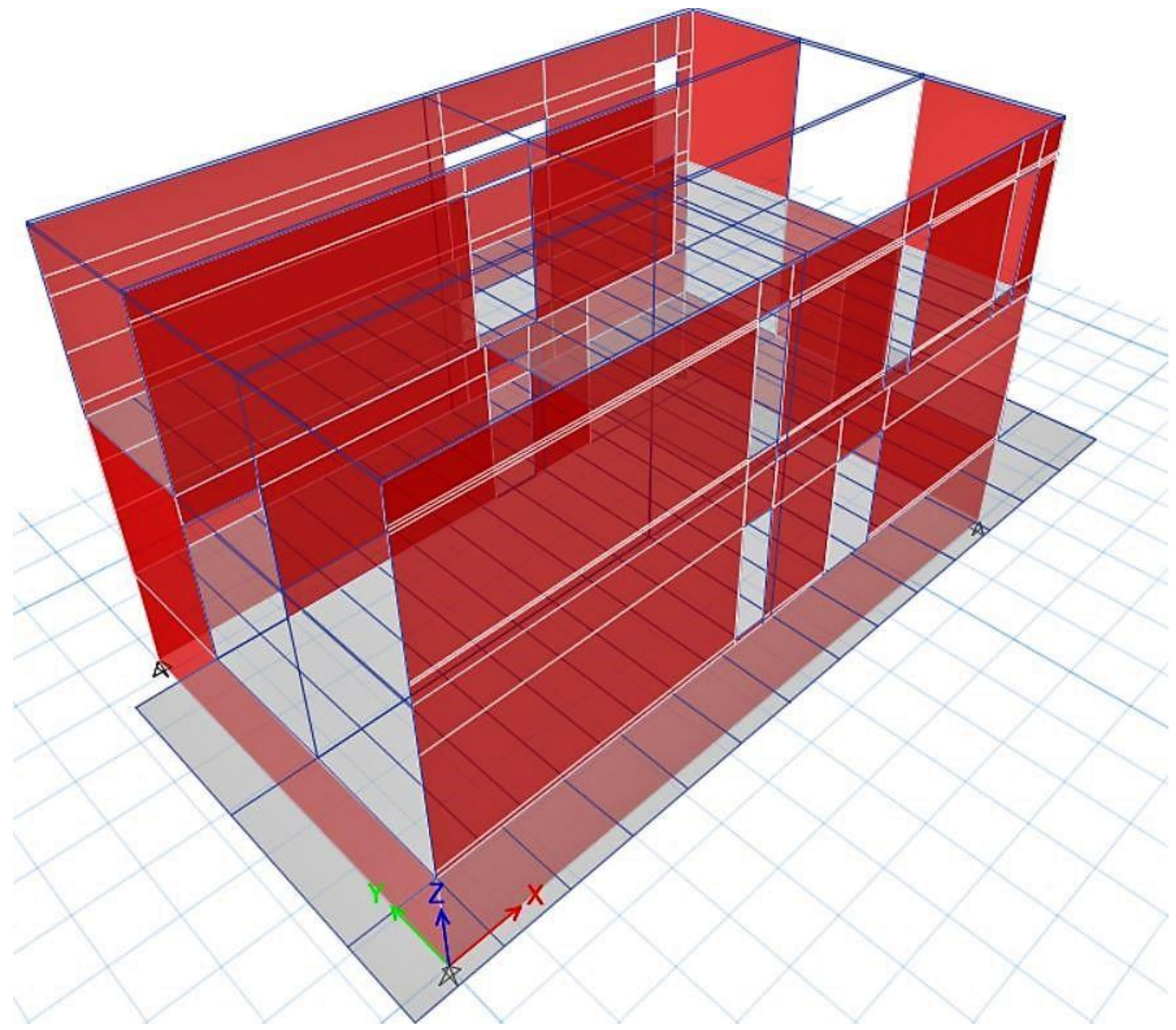

Figure 17. ETABS model. 
Analysis and design process were done according to the in-built structural element of ISO container consisting of the envelope around the container and the side rail top and bottom beams and also the columns at the corners. Also, in area of the openings the strengthening elements were added to the model to simulate the real situation. Example of deformed shape of the Frame 1 under Load combination UDStlS21 is shown in Figure 18 considering that the openings were retrofitted accordingly.

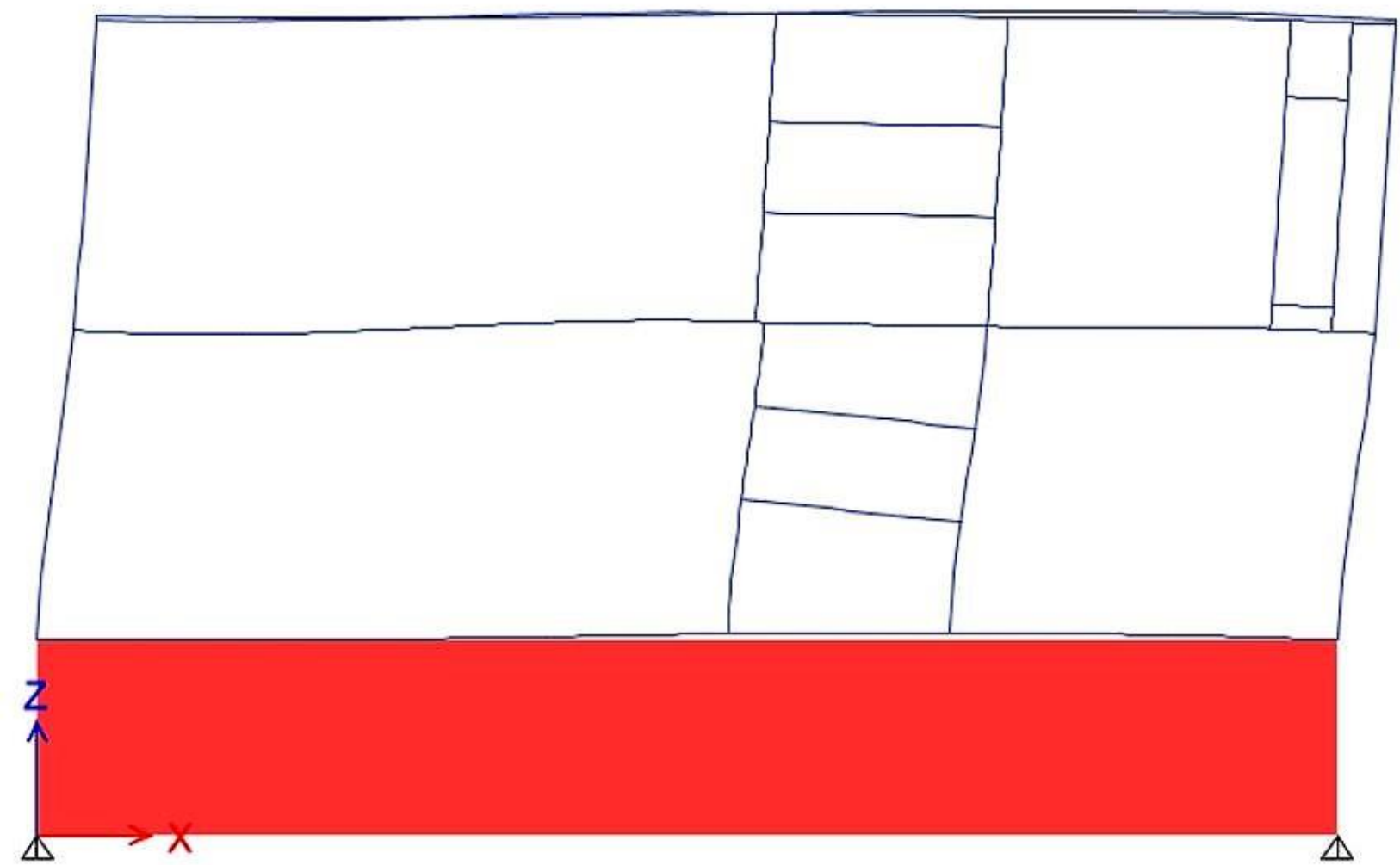

Figure 18. Deformed shape of frame 1 under load combination UDStlS21

The envelope was modeled as a $2 \mathrm{~mm}$ flat steel shell wrapping the container which could bring less stiffness compared to the real wall which is corrugated and its stiffness is much higher as it is less likely to be susceptible to buckling due to its physical barrier. As a result, we would end up with a good simulation of the real structure and stand on the safe side by underestimating the envelope stiffness. Plus, the deflections in the critical area in which the architect proposed the opening were 
compared to each other before and after retrofitting and the retrofitting effect of the deflections of some critical areas were significantly restricted.

The need for reinforcing the structure in the area of opening was the contributing factor in this case study which determine the structure integrity and also limit the deflection in those critical area. In this regard we ran the analysis and design two times, one time without the reinforcing elements and the second time with the proposed strengthening elements in the vicinity of openings. Having Run the model twice, it is concluded that in order to restrict the deflections due to critical load combination, the structure outperforms the first model in which we ignored the retrofitting elements. To clarify this argument, we define 8 points in frame 1 as Figure 19 in which the deflection under the two scenarios mentioned above were determined under the load combination DStlS8. These point are seemingly the opening corners which tent to deflect the most in the absence of the cut wall. The deflections were

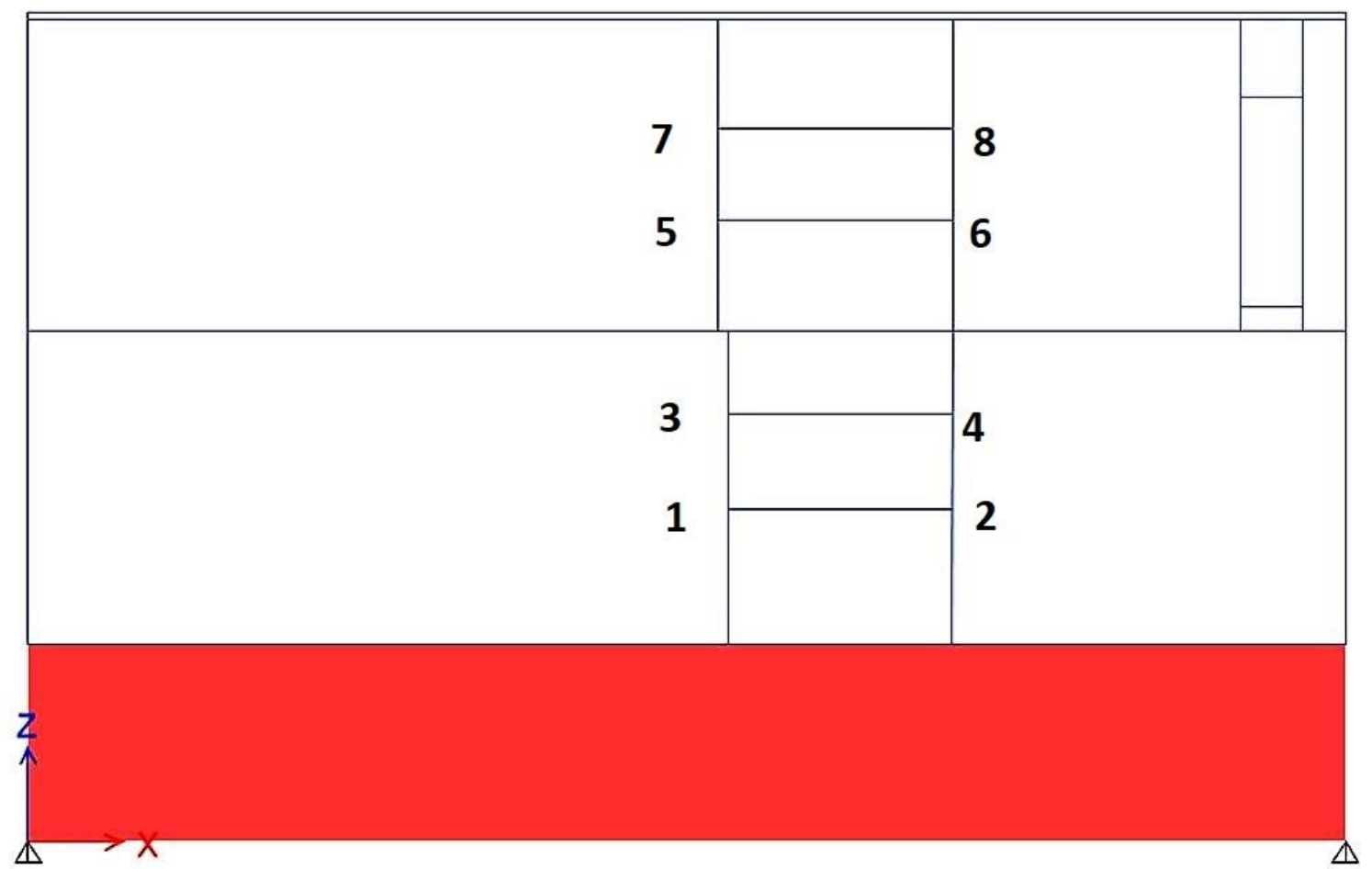

Figure 19. Eight point defined to compare the deflection with and without retrofitting. 
extracted as Table 7 and compared. As it is obvious, retrofitting the openings restricted the deflections and make it safer under any possible critical condition.

Table 9. Deflections for Nodes 1 to 8 compared in non-strengthened and strengthened status.

\begin{tabular}{|c|c|c|c|c|c|c|}
\hline \multirow{2}{*}{$\begin{array}{c}\text { Scenario } \\
\text { NODE }\end{array}$} & \multicolumn{3}{|c|}{ NON-Strengthened } & \multicolumn{3}{|c|}{ Strengthened } \\
\hline & $U_{x}(\mathrm{~m})$ & $U_{y}(\mathrm{~m})$ & $U_{z}(\mathrm{~m})$ & $U_{x}(\mathrm{~m})$ & $U_{y}(\mathrm{~m})$ & $U_{z}(\mathrm{~m})$ \\
\hline 1 & $1.98 \mathrm{E}-4$ & -0.0108 & -0.45 & $2.25 \mathrm{E}-5$ & $-3.12 \mathrm{E}-5$ & $-5.15 \mathrm{E}-3$ \\
\hline 2 & -0.003 & -0.089 & -0.409 & $-6.21 \mathrm{E}-5$ & $-1.56 \mathrm{E}-5$ & $-2.12 \mathrm{E}-4$ \\
\hline 3 & 0.015 & -0.101 & -0.477 & $4.14 \mathrm{E}-4$ & $-3.14 \mathrm{E}-5$ & $1.09 \mathrm{E}-4$ \\
\hline 4 & 0.014 & -0.078 & -0.413 & $2.89 \mathrm{E}-3$ & $-3.15 \mathrm{E}-3$ & $-5.55 \mathrm{E}-5$ \\
\hline 5 & -0.035 & 0.008 & -0.444 & $-3.65 \mathrm{E}-3$ & $2.12 \mathrm{E}-4$ & $-3.12 \mathrm{E}-3$ \\
\hline 6 & 0.034 & -0.007 & -0.42 & $3.12 \mathrm{E}-4$ & $-6.16 \mathrm{E}-2$ & $8.51 \mathrm{E}-4$ \\
\hline 7 & -0.044 & 0.116 & -0.444 & $-6.16 \mathrm{E}-3$ & $3.12 \mathrm{E}-4$ & $-3.99 \mathrm{E}-3$ \\
\hline 8 & -0.043 & 0.058 & -0.422 & $-5.93 E-3$ & $4.69 \mathrm{E}-4$ & $-5.67 \mathrm{E}-3$ \\
\hline
\end{tabular}

In which:

$U_{x}, U_{y}$ and $U_{z}$ are the deflection in the $\mathrm{x}, \mathrm{y}$ and $\mathrm{z}$ directions respectively.

As can be seen by comparison the deflection under the same load combination decreased significantly due to the elements added around the corner. Other nodes far from the openings behave almost the same with and without strengthening.

In terms of the design, the design ratio for 57 elements in the case if unrestrained opening happened to exceed 1 which make the in-built element to not be sufficient enough to withstand the critical load combinations suggested by NBCC 2015. The discuss aspects are shown in Figures 20 and 21 , respectively. 


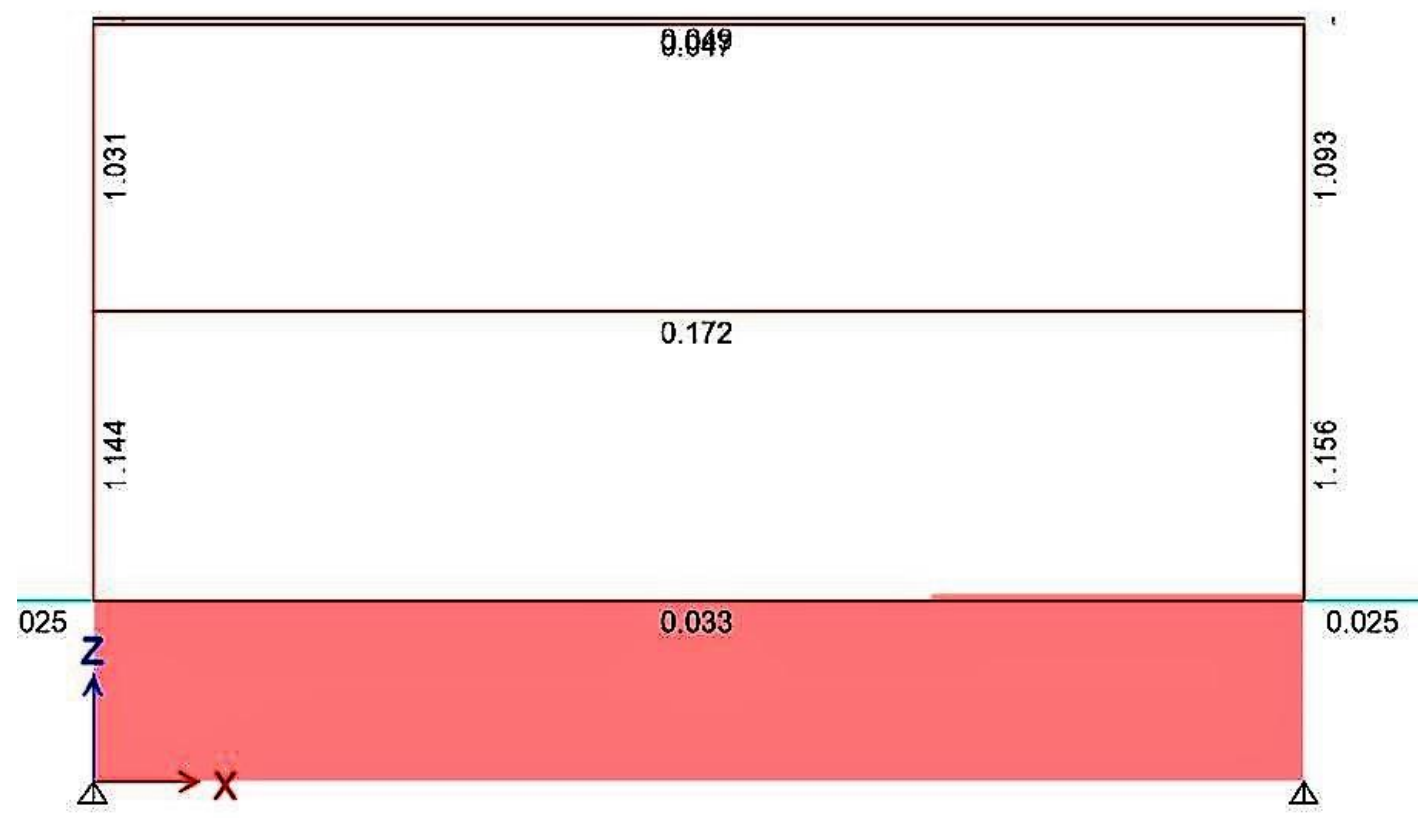

Figure 21. Design ratios for frame 1.

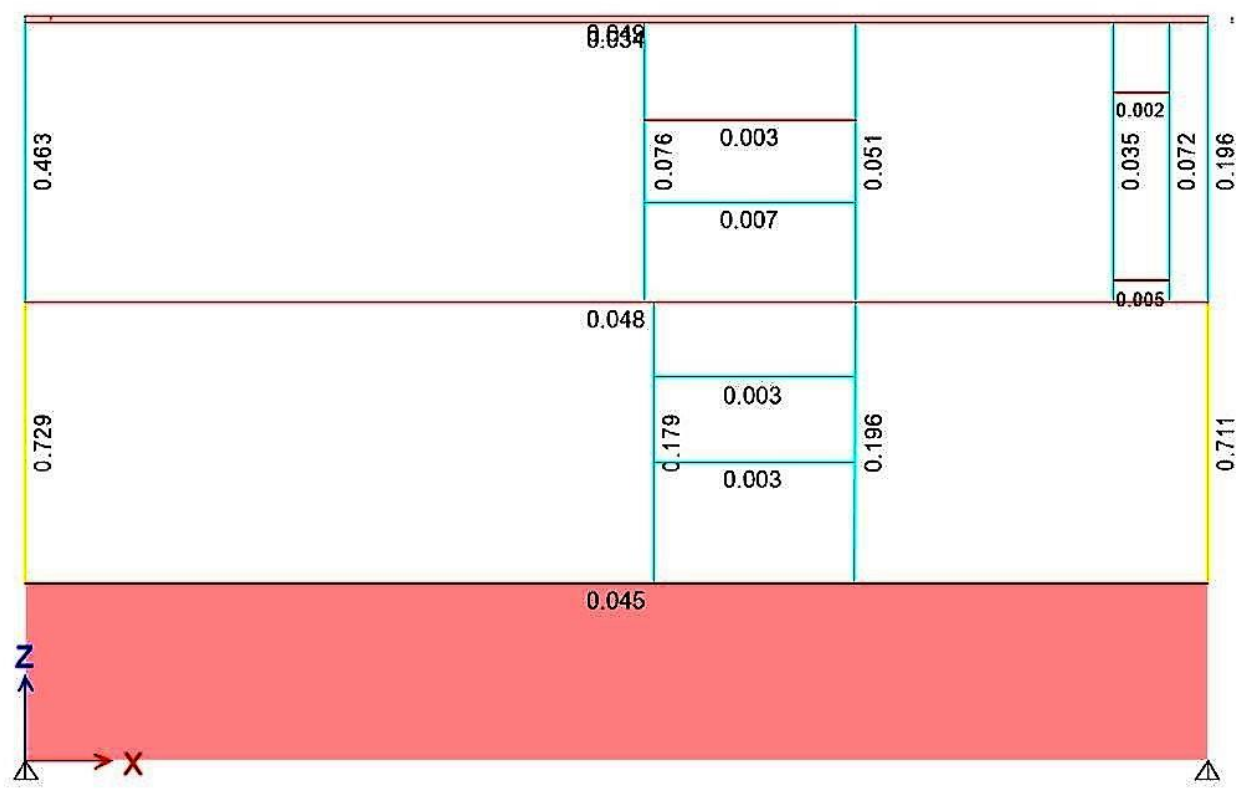

Figure 20. Suggested retrofitting elements decreased the design ration of in-built materials in frame 1.

\subsubsection{Structural drawings}

\subsubsection{Plans}

In order to elaborate the details, the structural drawing set has been completed containing the connections detail, wall and foundation detail, cutouts and modifications. However, due to the high 
volume of drawing sheets prepared it is out of the report outline to bring them all here but as examples some views have been shown here. In the Figure 22, you can see the proposed plans of each story. Containers stacking on top of each other have been named from C1 to C6.

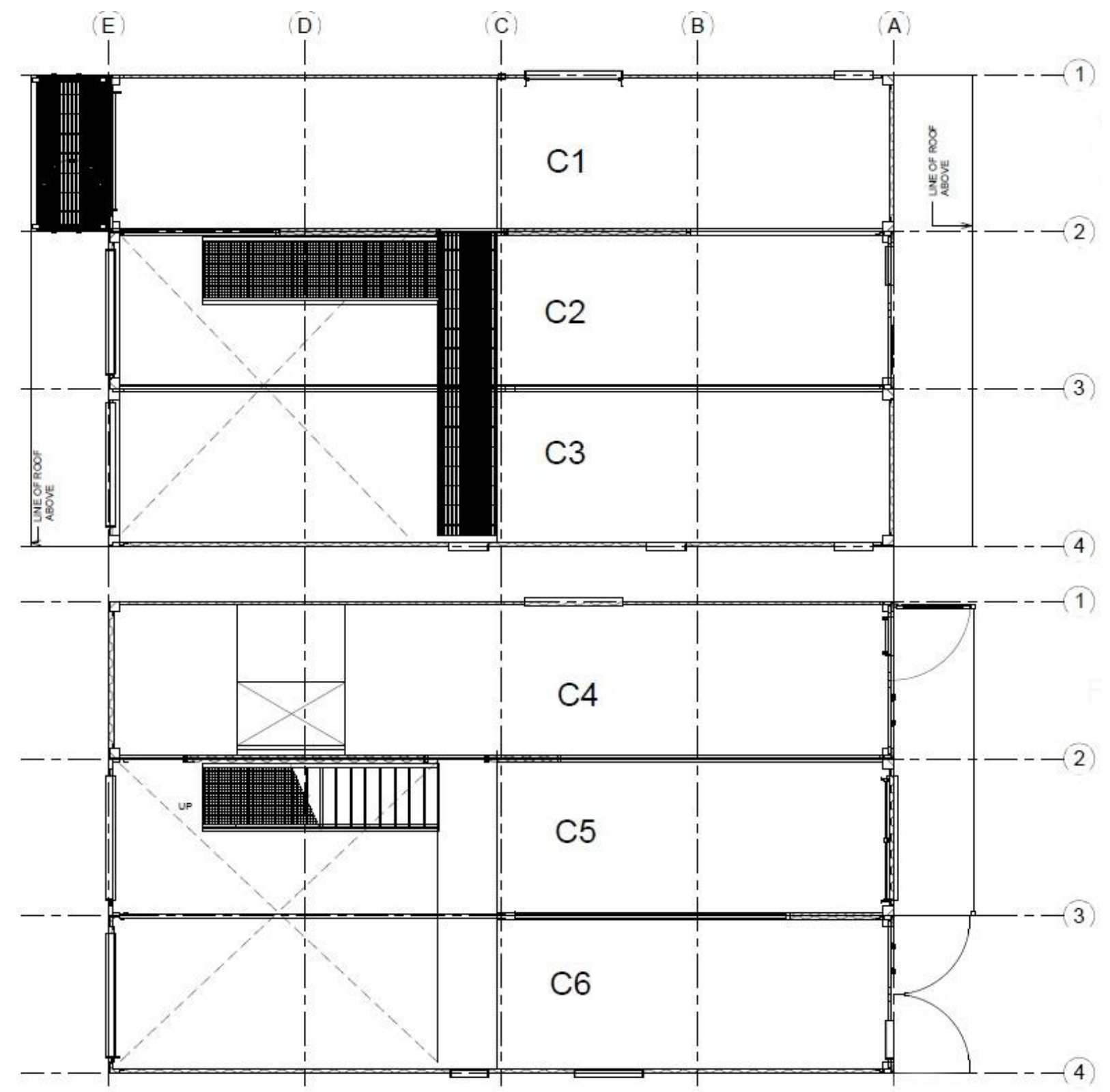

Figure 22. TOP: second floor plan consisting of container numbers 1, 2 and 3. BOTTOM: first floor plan consisting of container numbers 4, 5 and 6. 


\subsubsection{Elevations}

In the elevation view, the containers elevations and numbers are more obvious. All the windows and openings are strengthened according to common practice and client needs. In the Figure 23 below the North and East elevation of the structure are shown, respectively.

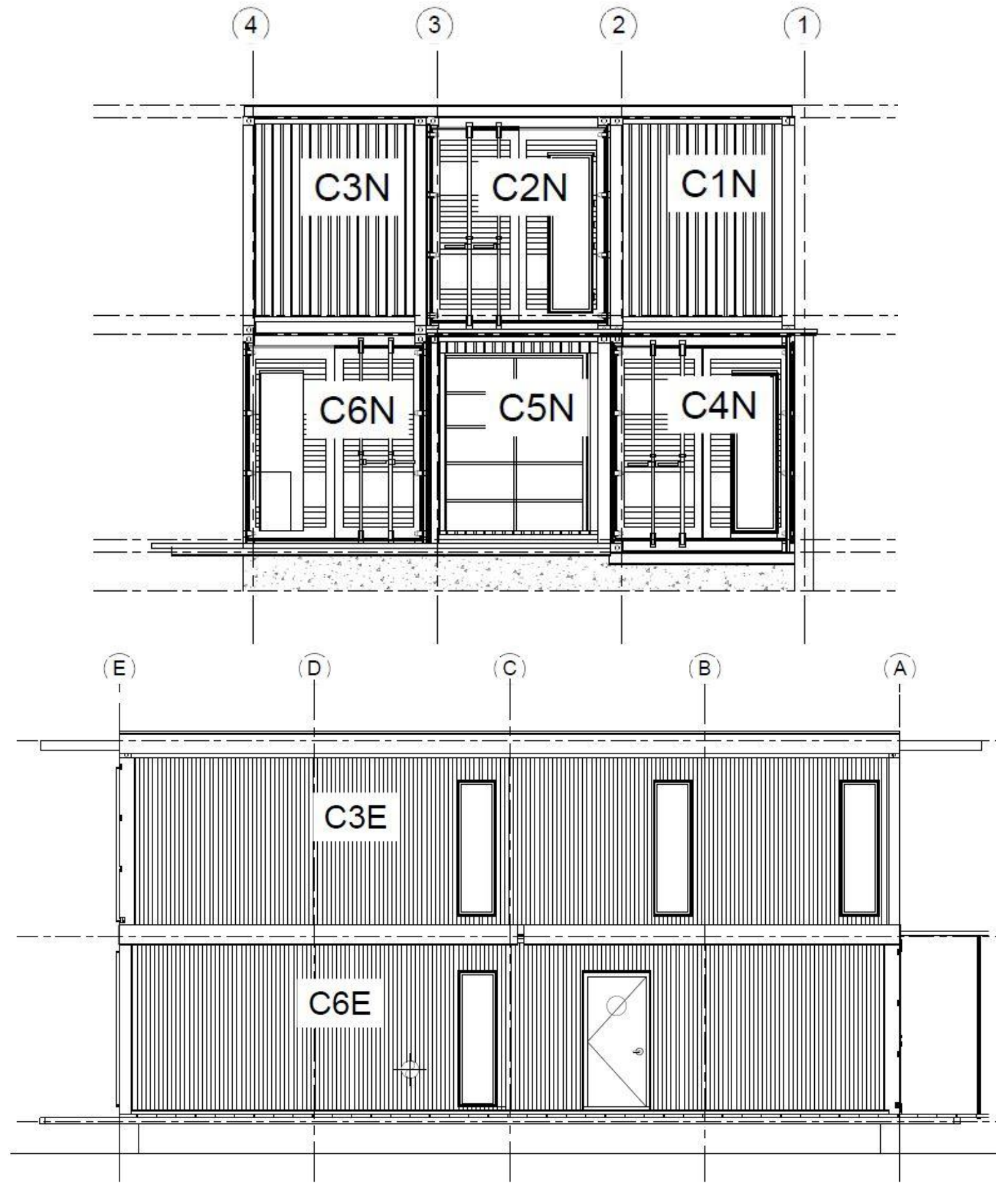

Figure 23. TOP: North elevation, BOTTOM: East Elevation 
For each container, cutout and framing drawings have been drawn according to the architectural plan and all the retrofitting materials and the connection types have been mentioned in order to clarify the drawing setup as much as possible. 42 set of drawing sheets were added into the supplementary documents which clearly cannot be shown here completely. For instance, the container C5 has to be cut as Figure 25 in its west side to be able to accommodate the strengthening elements as suggested by Figure 24 .
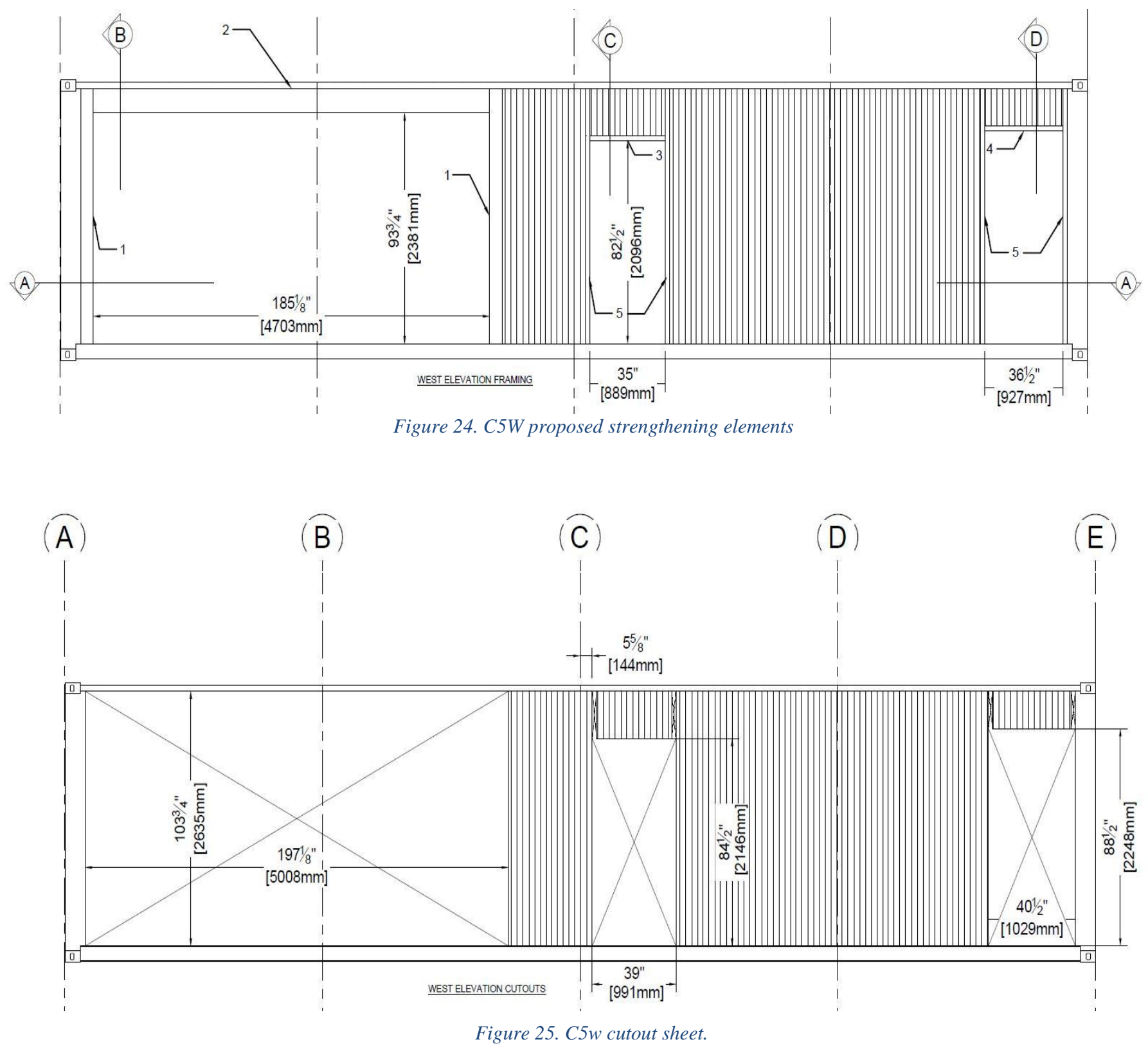
As can be seen, different sections such as A-A, B, C and D have been drawn to make the fabricate process more clear for the welders in the shop as Figure 25. Figure 26 depicts the Section AA and the elements retrofitting that section. Moreover, Figures 27and 28 demonstrate sections B, C and D offered in the Figure 22. The material used in the Figures 22 to 26 are tabulated in the table 8.

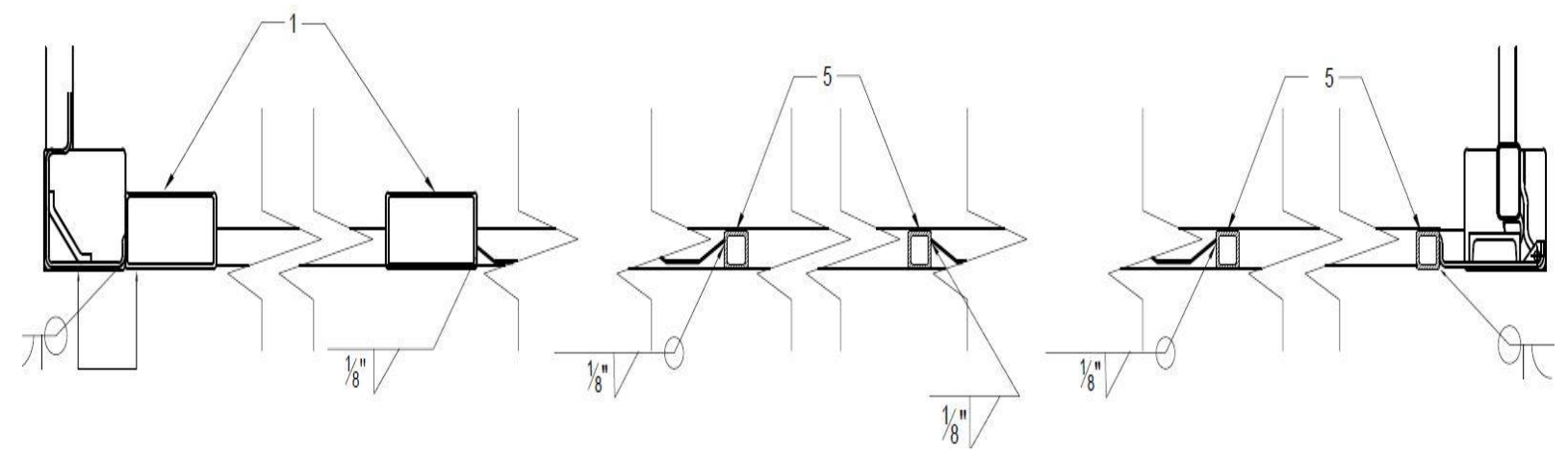

Figure 26. Section A-A in the Figure 24.

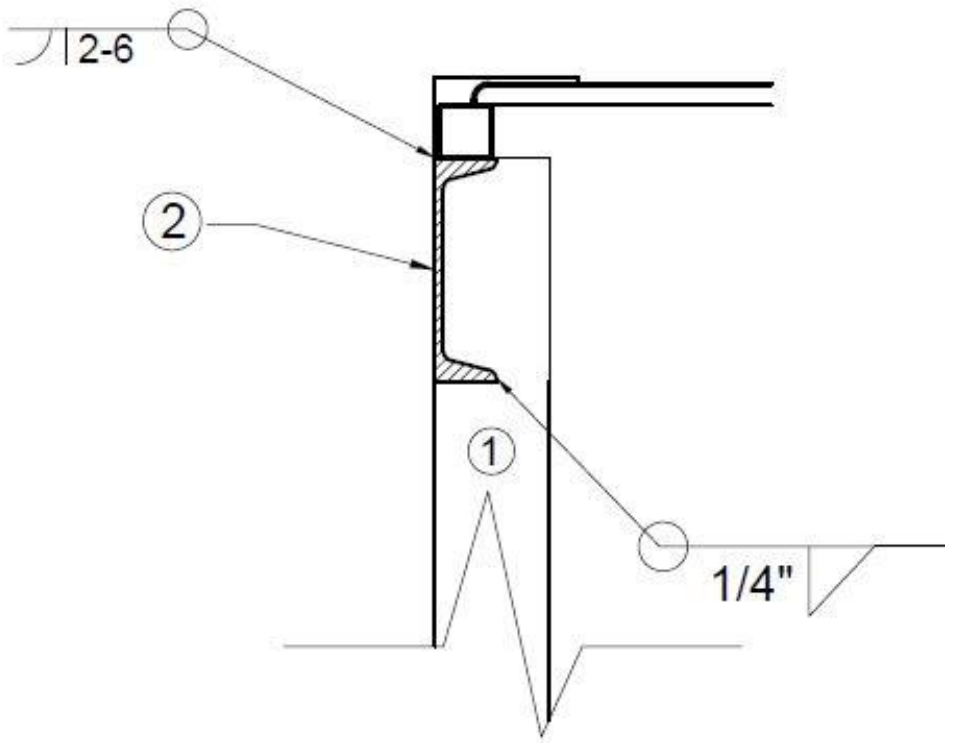

Figure 27. Section B in the Figure 24. 

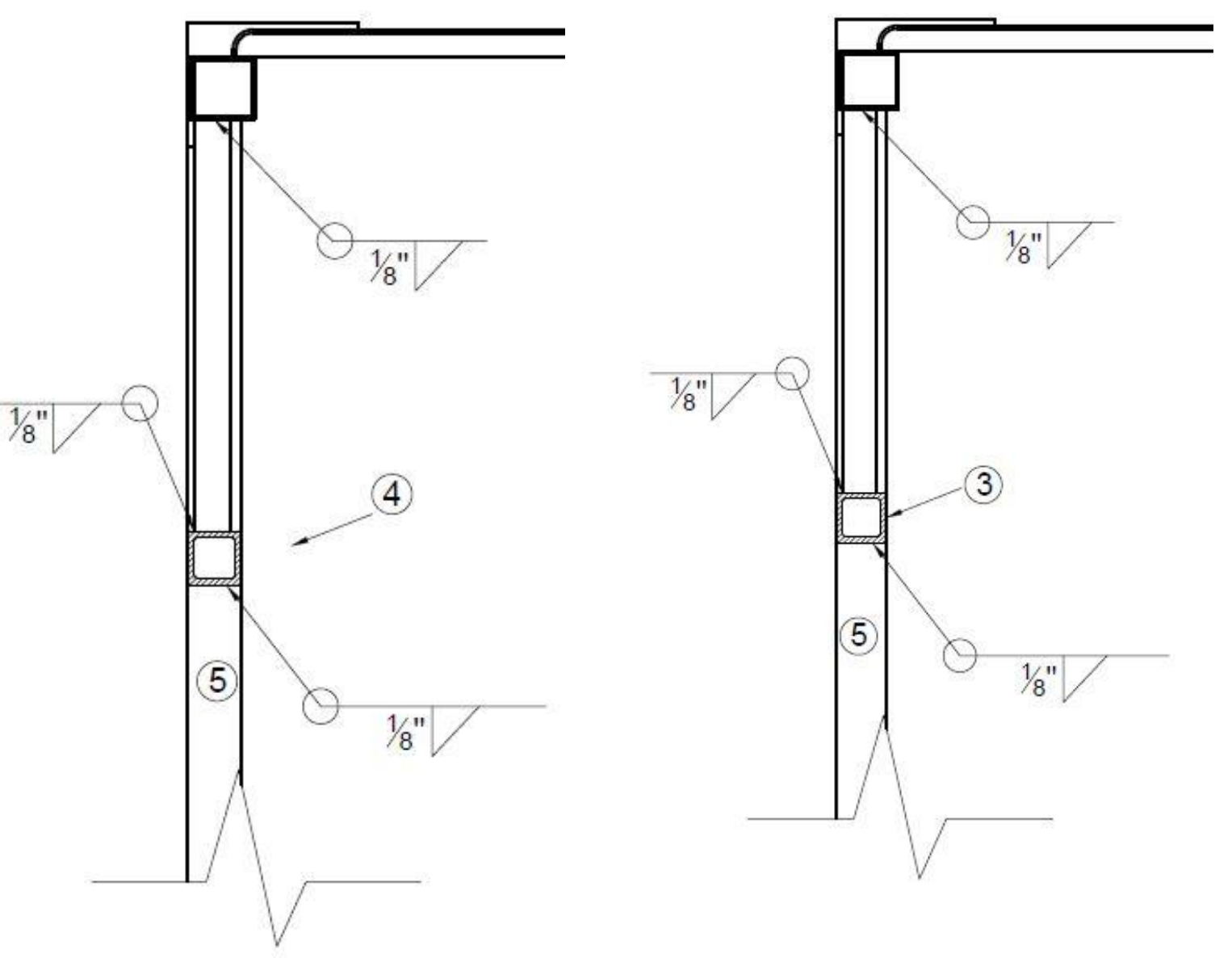

Figure 28. LEFT: Section C in the Figure 24. RIGHT: Section D in the Figure 24.

Table 10. Bill of material used in the C5W modification drawings.

\begin{tabular}{|c|c|c|c|c|}
\hline No. & DESCRIPTION & LENGTH & QTY & NOTES \\
\hline$\overline{1}$ & $3 / 16^{\prime \prime}$ Steel HSS $6^{\prime \prime} \times 4^{\prime \prime}$ & $1033 / 4$ & 2 & CUT TO SIZE \\
\hline$\overline{1}$ & C10×20 Steel Struct. Channel & $1851 / 8$ & 1 & CUT TO SIZE \\
\hline 3 & $3 / 16^{\prime \prime}$ Steel HSS $2 " \times 2 "$ & 35 & 1 & \\
\hline 4 & $3 / 16^{\prime \prime}$ Steel HSS 2"x2" & $361 / 2$ & 1 & \\
\hline 5 & $3 / 16^{\prime \prime}$ Steel HSS 2"x2" & $1033 / 4$ & 4 & CUT TO SIZE \\
\hline
\end{tabular}




\subsubsection{Cutouts}

The floor is to be modified in some cases to accommodate the stairs into crawlspace and also to the second floor. Noting that part of the plan is open through the floor as can be seen in the Figure 22. In the Figure 29. You can see the floor cutout plan at top, floor framing plan at the middle and the

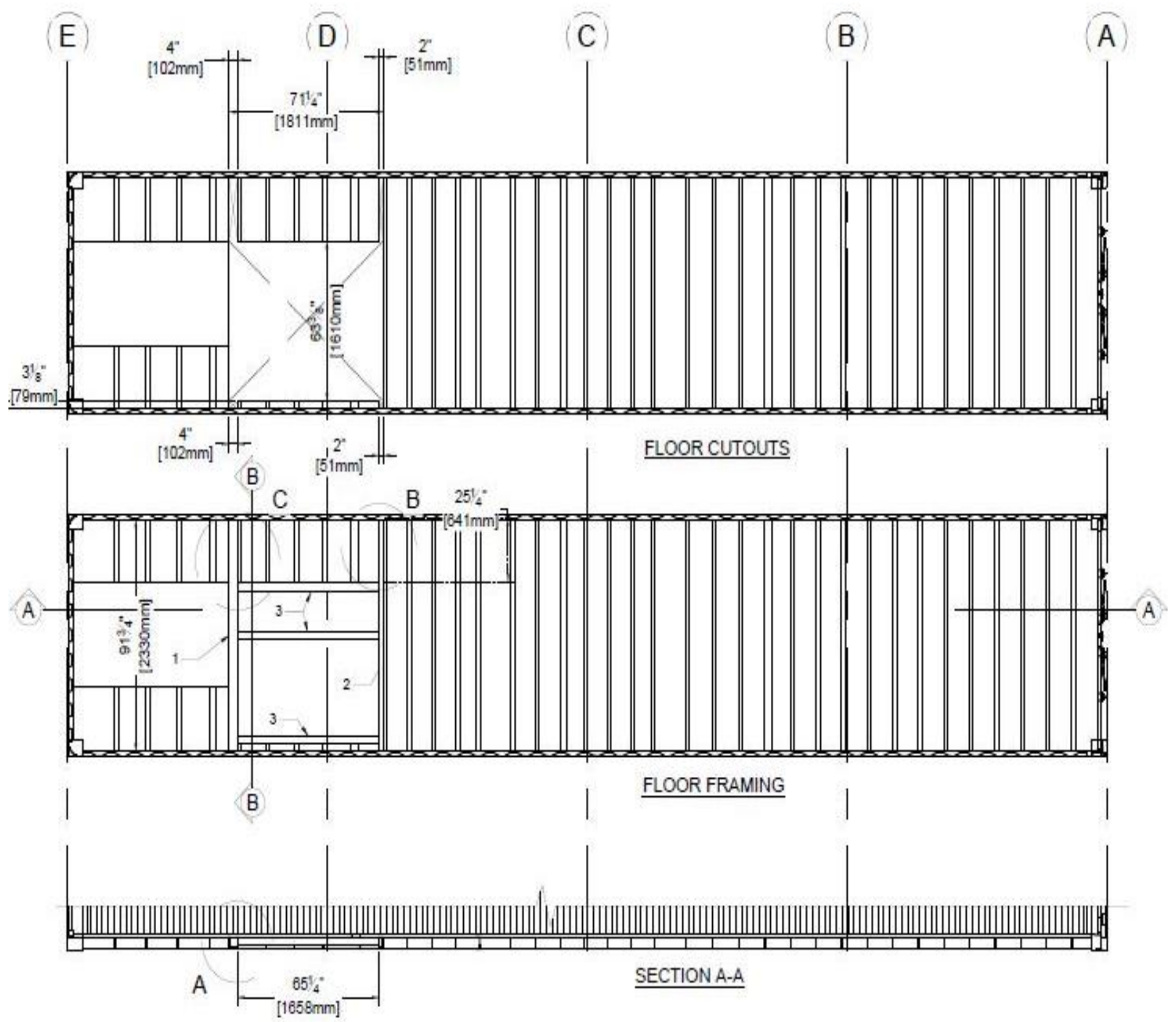

Figure 29. C4 container floor cutout and framing plan 
section A-A in the bottom noting that the cutout makes the way to the crawlspace for the residents considering that it was reinforced with $3 \backslash 16$ " Steel HSS 3" by 3".

Section B-B in the Figure 31 shows the cross section of the C4 container floor in the vicinity of stairs connecting the main floor to crawlspace as Figure 29. Also, Figure 30 determines the retrofitting required as Figure 29 determines for detail A and B. The cutout perimeter was strengthened using element 3,3 and 1 according to the Table 10 .
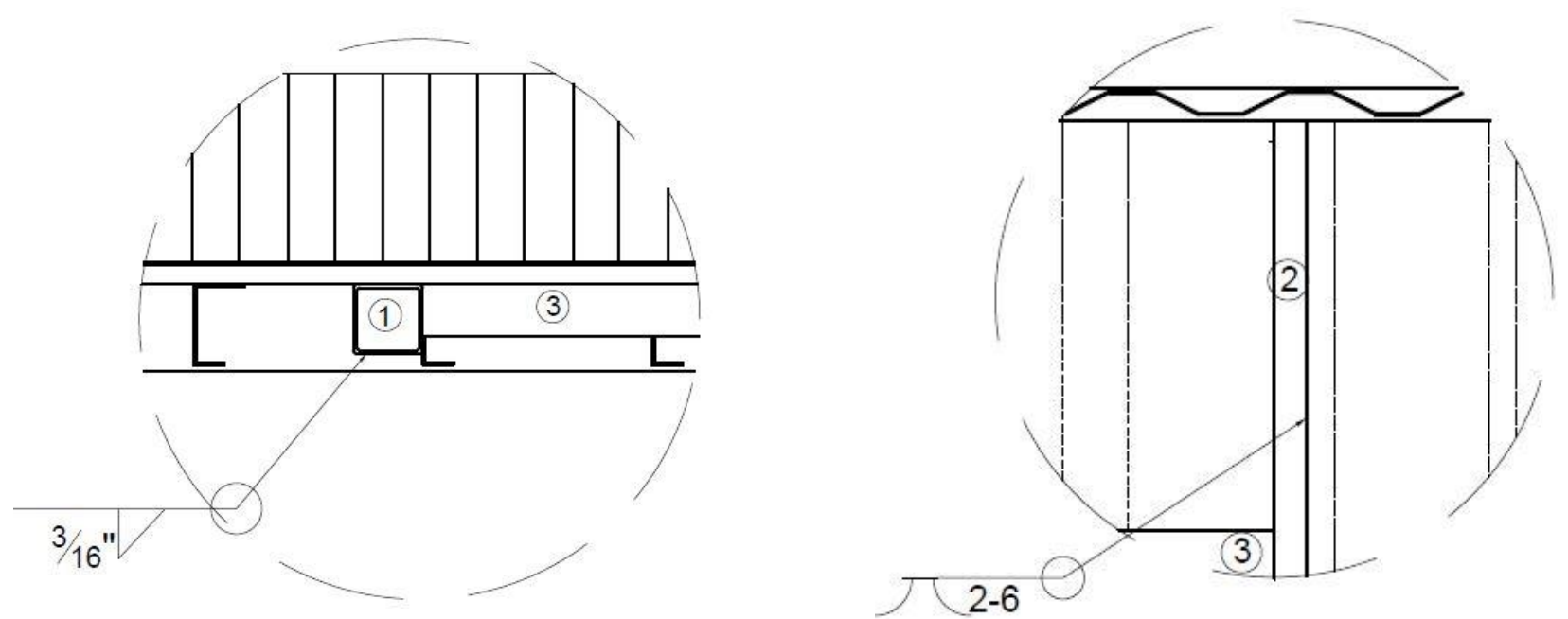

Figure 30. LEFT: Detail A of Figure 29, RIGHT: Detail B of Figure 29.

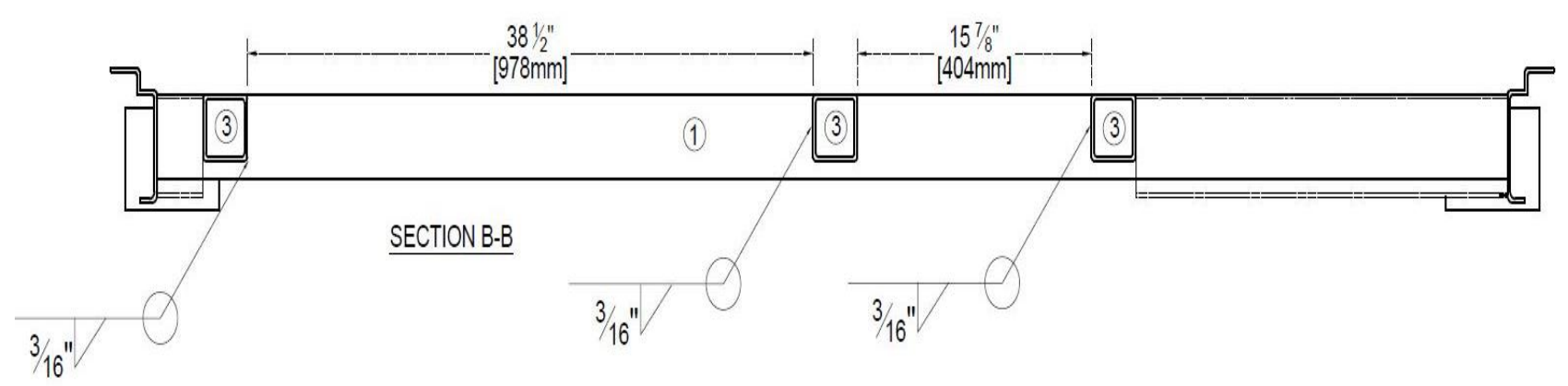

Figure 31. Section B-B of Figure 29. 
Table 11. Bill of material used in the Figure 29.

\begin{tabular}{c|c|c|c|c}
\hline No. & DESCRIPTION & LENGTH & QTY & NOTES \\
\hline 1 & $3 / 16^{\prime \prime}$ Steel HSS 4" $44^{\prime \prime}$ & $913 / 4$ & 1 & \\
\hline 1 & $3 / 16^{\prime \prime}$ Steel HSS 4" $2^{\prime \prime}$ & $913 / 4$ & 1 & \\
\hline 3 & $3 / 16^{\prime \prime}$ Steel HSS 3" $\times 3^{\prime \prime}$ & $651 / 4$ & 3 & \\
\hline
\end{tabular}

\subsubsection{Foundation and footing}

The foundation system consists of a 12 " by 24 " concrete footing and concrete wall with the thickness of 12". The reinforcements for wall mesh of 10M with the specified dimensions are obvious in the foundation drawing sheet and also the crossties provided in the perpendicular direction. Concrete cover in the vicinity of the soil is chosen to be 3 ". Additionally, the crawlspace 6" thick slab with the $4 * 4$ mesh has been provided to create the space for the services and maintenance. In the wall footing system all the reinforcements used are 10M except for the bottom layer of footing which chosen to be 15M. Figure 32 depicts the foundation and wall plans. Three sections have been elaborated to show the rebar arrangements and all the necessary information as Figure 33.

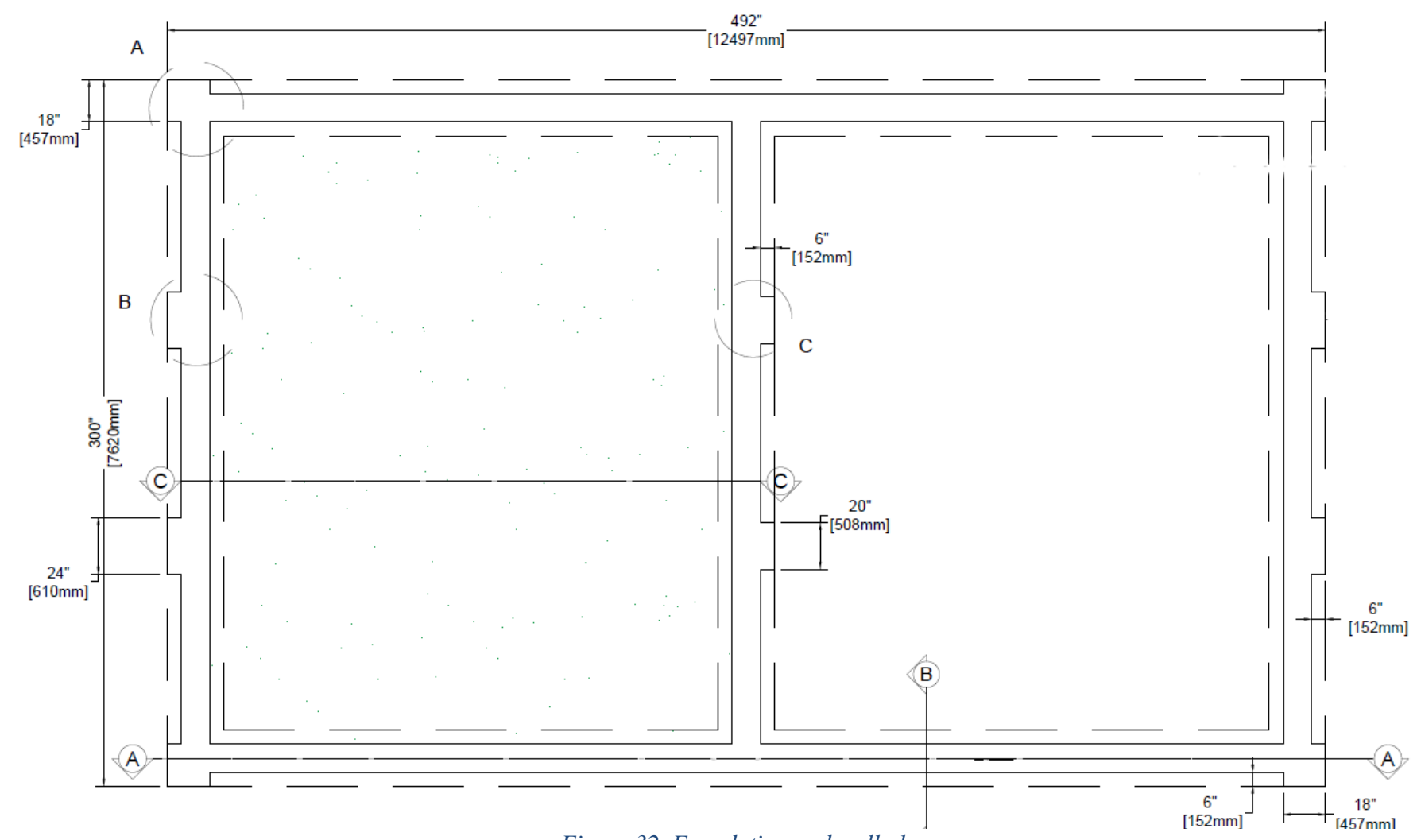

Figure 32. Foundation and wall plan. 


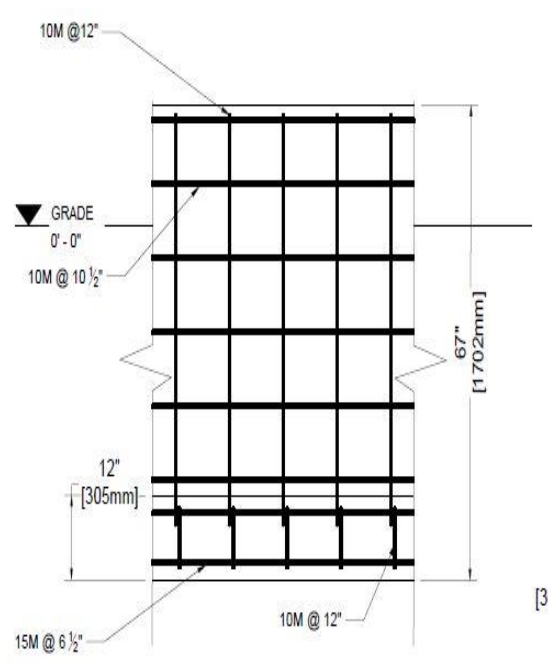

SECTIONA-A

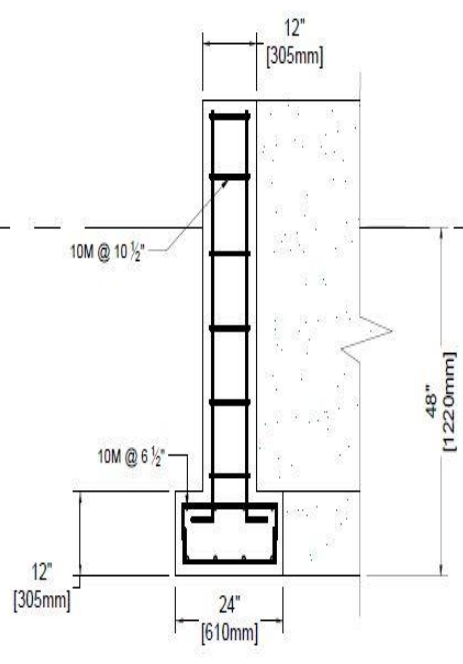

SECTIONB-B

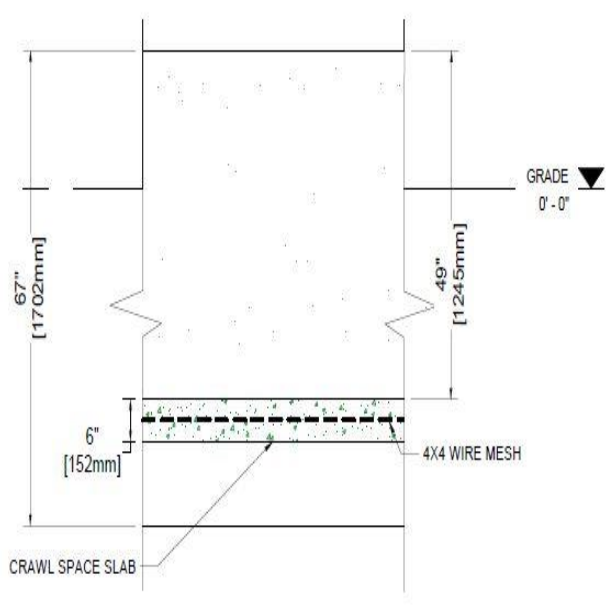

SECTIONCC.

Figure 33. Sections A-A, B-B and C-C of Figure 30.

Additionally, Figure 34 elaborates different details of A and B, in which the rebar and tie arrangements have been shown in the corner of the wall, in the vicinity of base plate in the middle concrete wall.
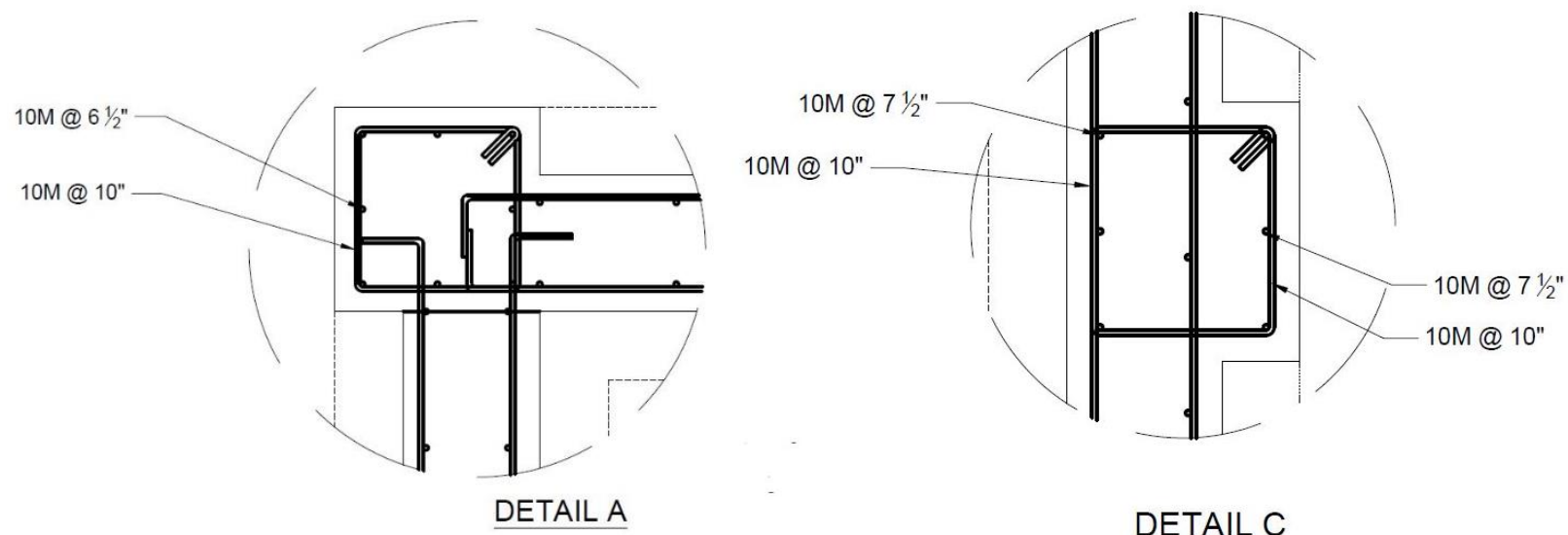

Figure 34. Details A and C of Figure 32. 


\subsubsection{Connections and Base Plate}

The connection of the containers together and to the concrete wall beneath is designed to be carried out by the means of base plates consisting of steel plates and angels and anchor bolts embedded inside the wall, respectively. The connections were calculated between the containers and around their external envelope to maintain the integrity of the structure at its upmost level. Figure 35 and 36 elaborate the connection details more. Also, Table 11 shows the material used in Figure 35 and 36.

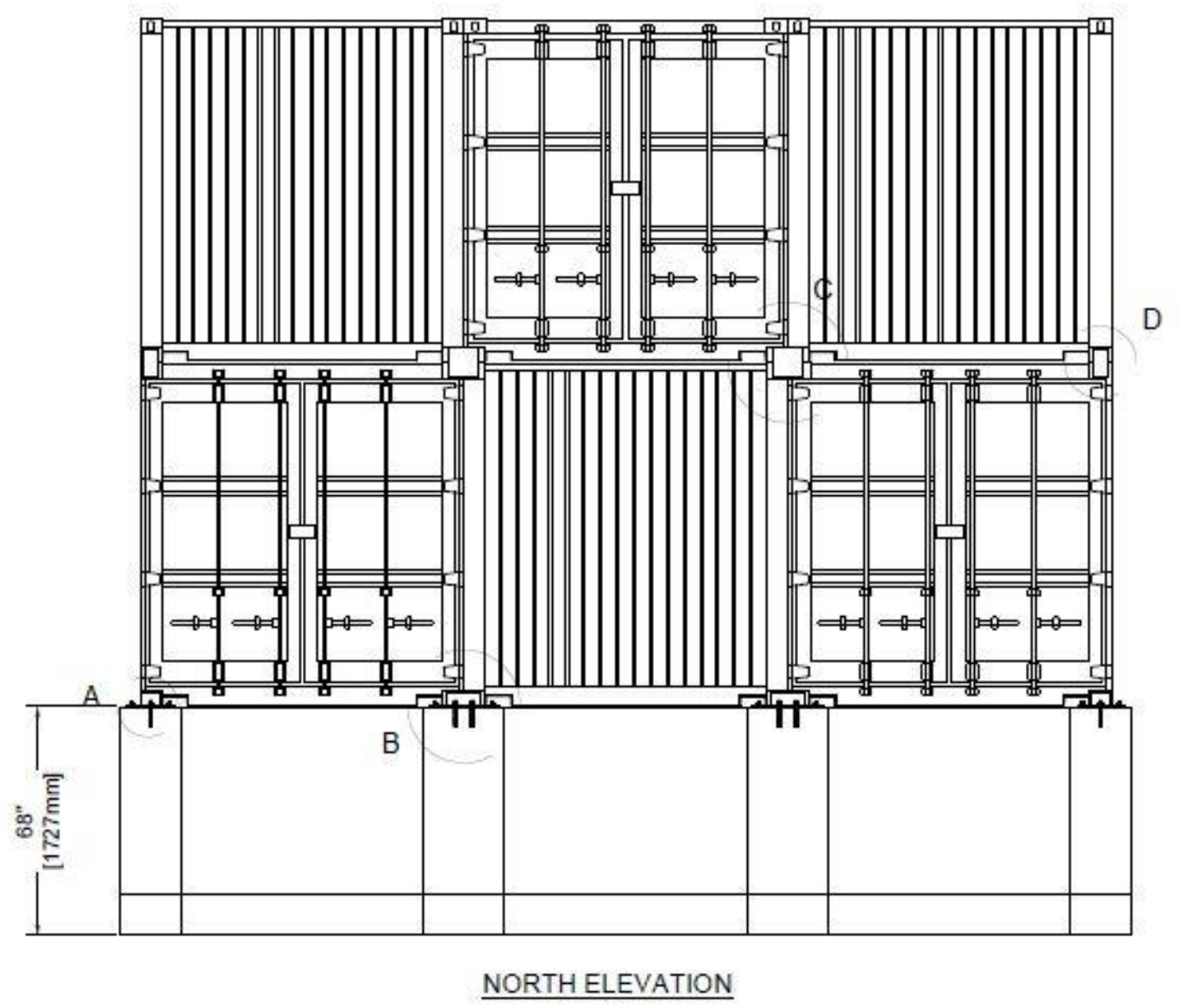

Figure 35. North elevation Connection details 

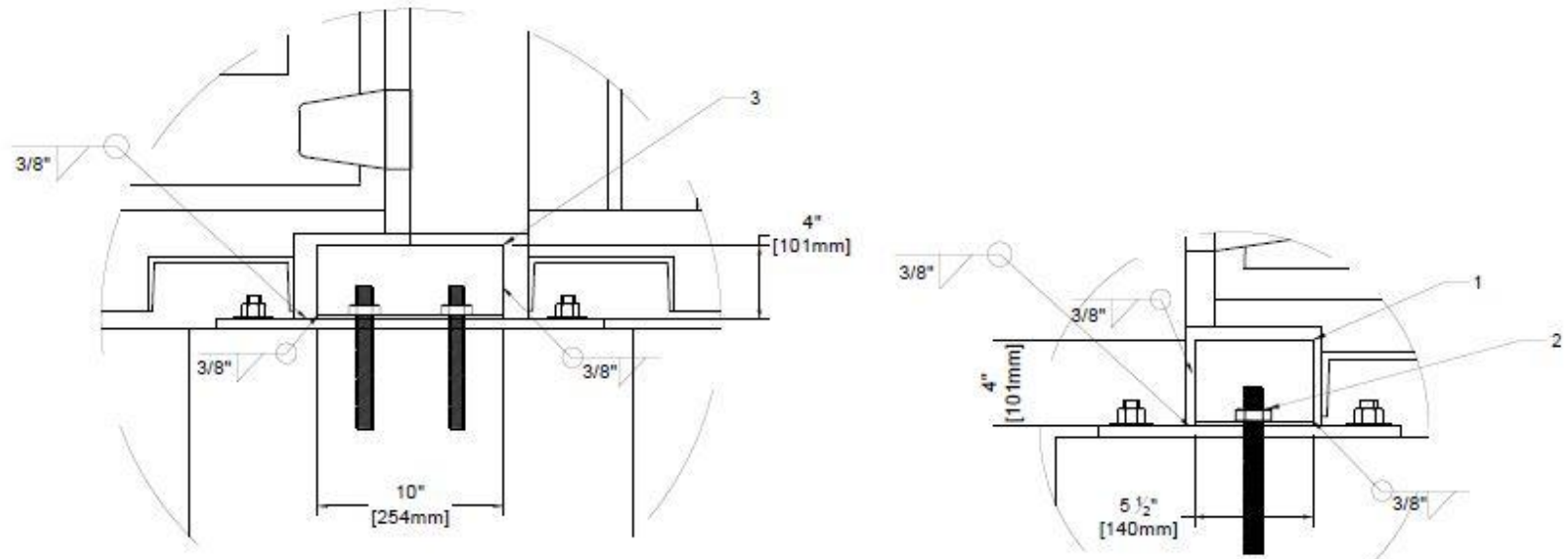

DETAIL A

DETAIL B

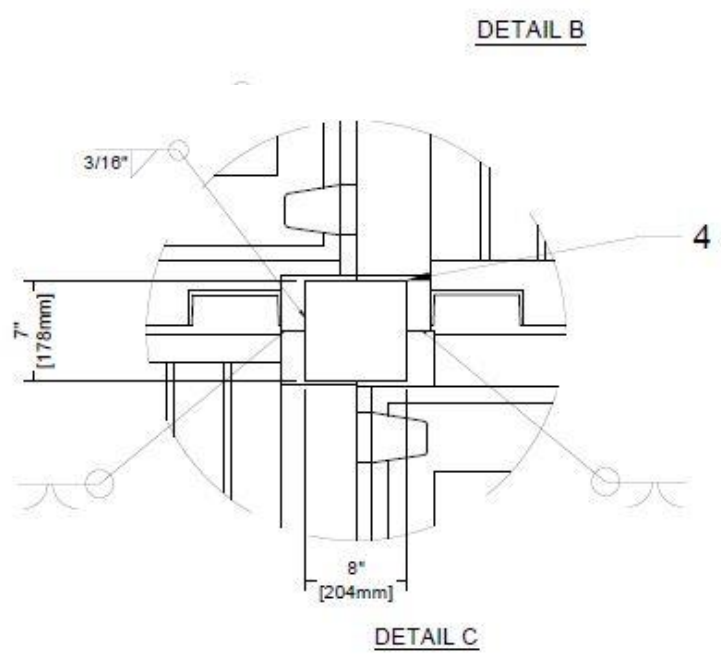

DETAIL C

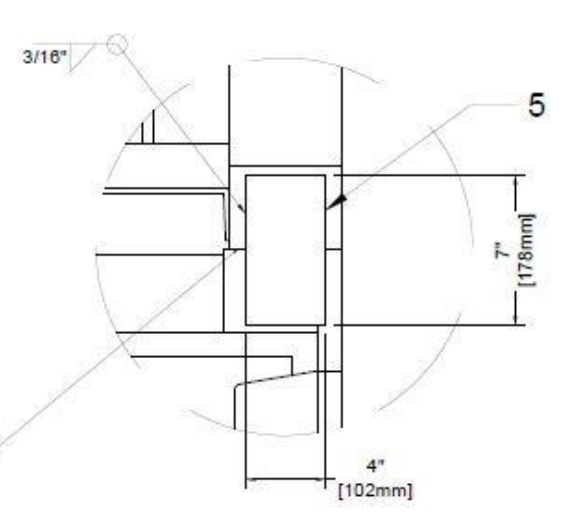

$\underline{\text { DETAIL D }}$

Figure 36. Details A, B, C and D of Figure 35

Table 12. Bill of materials used in the Figure 35 and 36.

\begin{tabular}{|c|c|c|c|c|}
\hline vo. & DESCRIPTION & LENGTH & QTY & NOTES \\
\hline 1 & ANGLE $4^{\prime \prime} \times 33^{\prime \prime} \times 3 / 8^{\prime \prime}$ & $\begin{array}{ll}5 & 1 / 2\end{array}$ & & \\
\hline 2 & Expansion Anchor KB3 $1 / 2 " \times 51 / 2 "$ & $51 / 2$ & & \\
\hline 3 & ANGLE $4^{\prime \prime} \times 33^{1 / 2} \times 3 / 8^{\prime \prime}$ & 10 & & \\
\hline 4 & STEEL PLATE $7 " \times 88^{\prime \prime} \times \mathrm{Y}_{4}{ }^{\prime \prime}$ & 4 & & \\
\hline 5 & STEEL PLATE $7 " \times 4^{\prime \prime} \times \mathrm{Y}_{4}{ }^{\prime \prime}$ & 4 & & \\
\hline
\end{tabular}




\subsubsection{Columns}

Within the inside area of the containers, modifications have been designed in order to empower the structure's ability against cutout members. In some areas, the in-built steel wall is not removed and the strengthening elements welded to them to increase the lateral and gravity load resistance. In the Figure 37 and 38, the first floor modifications and two of three according details have been shown, respectively.
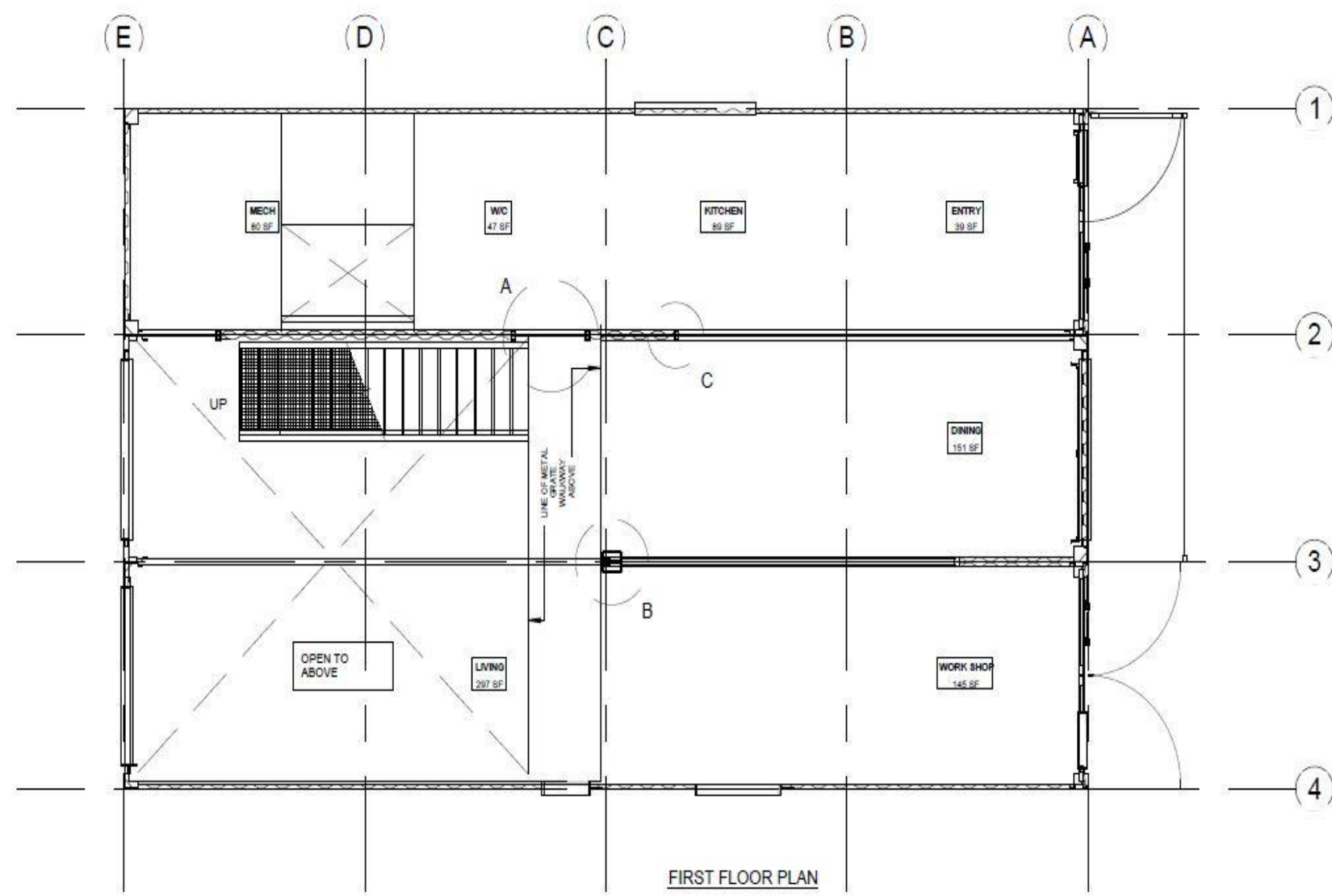

Figure 37. First floor modifications proposed 


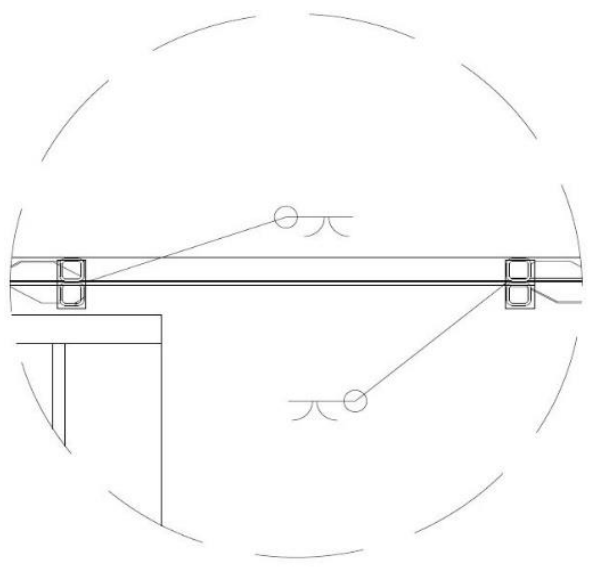

DETAIL A

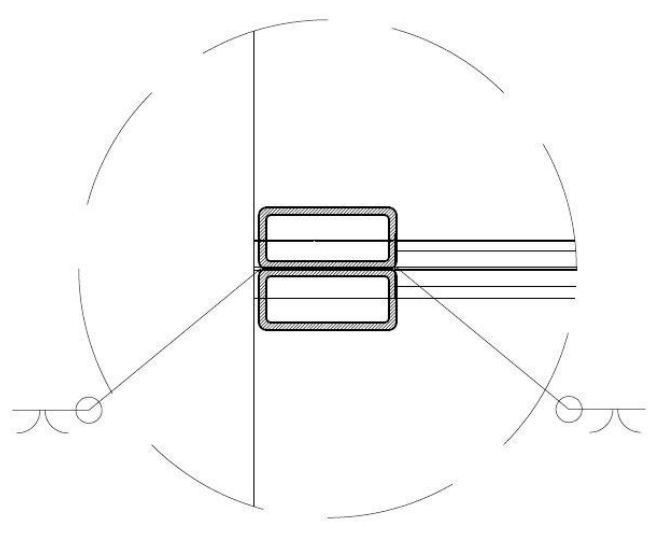

DETAIL B

Figure 38. Details A and B of Figure 37. 


\section{Discussion and suggestions}

\subsection{Introduction}

ISO container house is not so common here in Canada but it is going to develop further as it provides the customers with relatively affordable design and also quick set up procedure. In terms of the cost, it could be even cheaper when the customer gives permission to use the second handed as the prime structure as it depends on their opinion. So the potential growth within the market could be considerable in the following years, the point which should be highlighted for business owners.

The labor cost decreases considerably as the installation process would not take so long but the need for crane operator and a professional welder seem to be significant. The cutout process and retrofitting could be executed in the shop prior to transformation into the site to minimize the possible mistakes considerably. On the other hand, in some cases the site based modifications may be preferable based on each specific project so the designer is the one who decides on where is the best place to perform the desired modifications.

The insulation process should be taken seriously on the ground of the weakness of ISO containers in temperature exchange rate. Polyurethance spray-foam insulation has been used as an insulator agent in this project which is confirmed to be one of the best insulator agent regarding to its cost. The insulation issued has to be taken one of the most significant ease contributor in the ISO container building.

\subsection{Suggestions}

As discussed before, special care should be given toward the opening areas in which the lack of in-build container wall could contribute to over-deflection and even failure. The intrinsic characteristics of ISO container is to withstand considerable forces as we talked about it before, but at 
the same time the excessive cutout modification could lead to unstable structure. The strengthening element should be chosen the one that the contractors are most comfortable with and looking at the financial aspect be affordable. The modification process should not be deeper than needed to reach the goal of getting the best place to live with the lowest price possible and lowest energy consumed. The drawings should be simple and vivid to avoid any misunderstanding as well.

The weld procedure must be supervised thoroughly as due to its difficult process; the lack of skilled labor could bring about some weld-fault which is not acceptable. it is highly vital process of the modification which should be taken place at the shop before transferring to the installation site. The designer could even take advantage of some sort of bolted connection which could be performed much easier than welding and almost every contractor like it better. The bolting needs less supervision compared to welding making it more suitable for remote construction site in the absence of approved welding supervisor.

Considering the connections between the containers, it is important to hold them together as much as possible so that they keep their integrity more in the case of significant lateral load applied to the structure. Usually, different designers have their own unique way of connecting but such as the standard locking mechanism offered for containers of even welding them directly into each other. However, it depends on the contractor preferences to utilize which type of connection latch, it might be the best to use some steel flat plate all over the structure and weld them thoroughly to obtain the most welding accuracy. Also, the external envelope which is exposed to the naked eyes should be finished as clean as possible so welding the bottom rail of ISO containers directly into each other would not be an option in terms of aesthetical issues.

For the foundation design, usually the uplift force could be the contributing factor in determining the base plate dimensions and sizes. Due to the light weight of ISO containers, the forces 
applied at the basement wall are not a big concern compared to any ordinary structure. Designer ought to make sure that he satisfies all the critical aspects acting on different faces of base plate and make the rebar arrangement as clear as possible for the executing crew. All in all, the base plate setup and the bottom connection of containers to the concrete wall is not a point of concern unless some big uplift forces acts on one corner of structure.

\subsection{Design challenges}

\subsubsection{Aesthetical standpoint}

Buildings designed with the containers can be not so appealing for residential if you want to keep the authentic shape of structure consisting of exterior steel. They could resemble to big rectangular boxes and make the overall layout square and straight which could be seen like logo's pieces in the people's view. Usually, people prefer to have an open floor in their home which signifies the importance of fabricator and design team. As we discussed before, any kind of openings in the structure is ought to strengthen by extra member such as beams and columns to ensure the safety of the building. Also, with the help of some steel corrugated siding you can make your building similar to the neighborhood. Architects do not like to be restricted to predominated sizes as we have in ISO container building because it makes it more difficult to add their own architectural signature into the building.

\subsubsection{Pesticide treatment}

Unless you choose a brand new ISO container, the other one is to be treated with the strong pesticide. Pesticides clean the container and its components from any probable pest and diseases inside the structure. Any container bought is to be examined carefully from this standpoint and the container 
seller should provide all necessary actions to make sure that your container contains no harmful substances.

\subsubsection{Rust}

Almost all the shipping containers built from steel are sensitive to rust. Although they use marine grade steel with anti-corrosive properties, the extreme environment causes the container to degrade in terms of rust finally. Metal slowly corrodes and disintegrates while rusting which can cause either structural rust or Non-structural rust. Structural rust degrades the structural integrity of the prime member whereas Non-structural rust is a surface damage and is an aesthetical problem which can depicts a poor design practice in customer's mind. As we know, many bridge girders and structures are built from weathering steel. Weathering steel is helpful in extending the service life of the member but cannot completely eliminate the rust degradation in the harsh weather condition. It is known that in the humid subtropical climates, even the weathering steel would not be resistant enough in order to delay rust initiation.

Oxidation reaction due to moisture is the prime rust contributor. Therefore, it is recommended to keep the containers as dry as possible. Usually the bottom surface of the container doors is prone to collect water which appropriate consideration should be taken into account in order to keep it dry. As can be seen in Figure 39, in case of a container laid on the ground, the bottom surface of the container is to degrade more due to the elevated humidity it contacts with from the ground. 


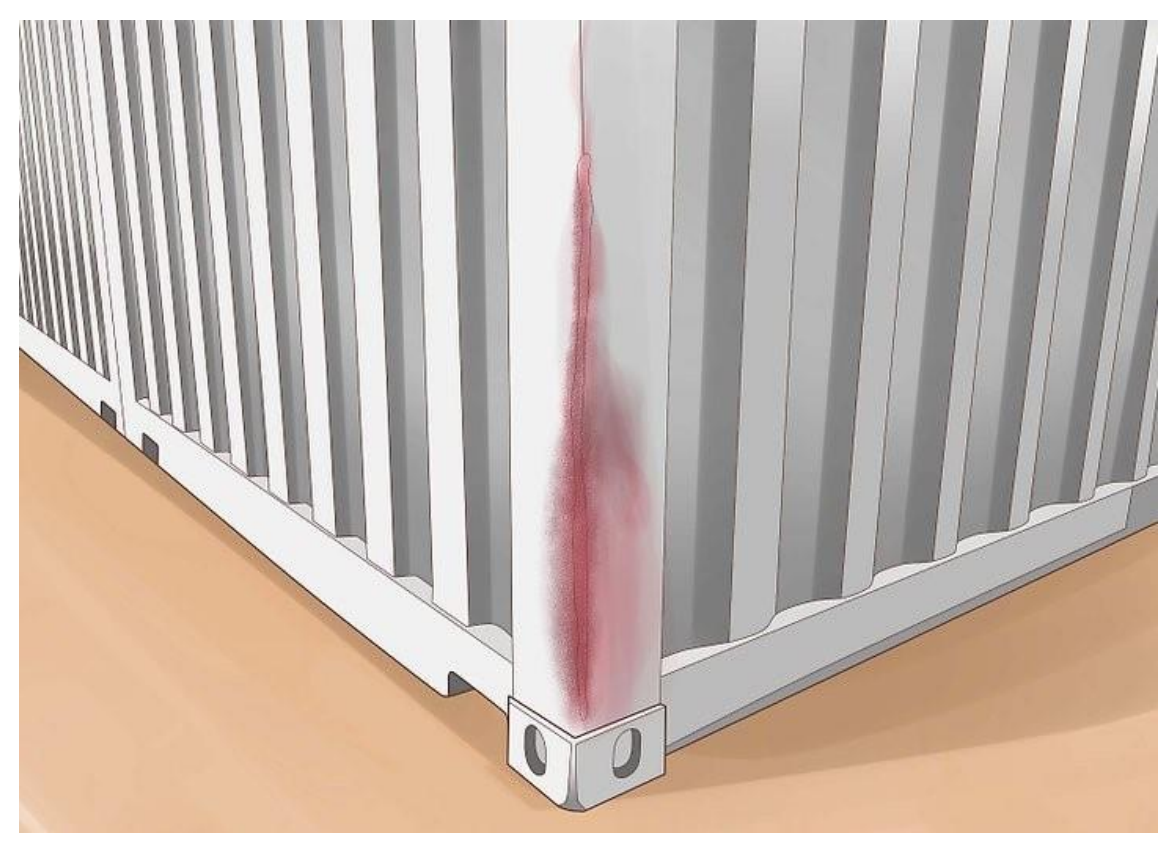

Figure 39. Rust ingress into ISO container.

An affordable solution to avoid this damage would be the use of the concrete footing which lifts the container and minimize its contact with the ground. In choosing a used container, thorough inspection should be applied before purchasing. Double check any rust degradation on the container's bottom or any other places which water may have collected it. Also, any deformation and dent in the appearance of the container should be checked because any damage could increase the ingress of humidity and water beneath the coating and threaten container's service life. Zinc coating could impede the container's rust considerably. The so-called process of Cathodic protection the zinc could slows down the rusting process of underlying steel. A zinc coating is qualified if it contains at least $90 \%$ dry zinc powder.

\subsubsection{Rust Treatments}

If the shipping container's rust in not on the structural member and would not harm the structural integrity, it can be treated if not too severe. One practical approach is grinding, sand 
blasting and chipping the rust away in the affected area. Recoating consisting of primer and topcoat should be considered when the steel beneath the rubbed area is obvious.

\subsubsection{Life-span Termination}

The condition in which the container is exposed to is the key factor in lime-span determination of the shipping container. Despite the fact that the containers are built with weathering steel, they have a limited lifespan. For instance, a container kept in a warm and dry environment is less likely to corrode than the one exposed to sea salt and water. Once any significant sign of detrimental damage is noted, they ought to be taken out of service. 


\section{Conclusion}

Based on the analysis result, we have concluded that the deflection of some nodes around the vicinity of cutting narrowly could exceed the allowable value. The dead and live loads are not mainly a concern in ISO shipping container homes while the different combination of them plus lateral load may cause the structure to deform excessively. Amount of the retrofitting depends on the opening and cutout process designed by the architect. In this regards, taking the deflection of the points around the opening into account seems to be most important thing in this project. In this project all the openings were strengthened to limit the excessive behavior of the structure while considering economic considerations. Another point in strengthening of the openings is that they usually are used by the contractors to install windows and doors. So the use of those strengthening elements also provide the sitting frame for them too. The amount of modifications needed depend on the application of the building and the modification method relies mostly on the designer's experience. Also, the common practice of the executer could play an important role in designing process. Noting that due to the almighty intrinsic characteristics of the ISO container against different type of loadings, the error margin is minimized which leads into less supervision needed for the project.

The connection of the container to the concrete wall is not a big of concern because the forces in the connection area are not so magnificent but we need to consider the uplift force in the mid-span of side-rails due to lateral buckling of them. So some sort of lightly designed base plate would satisfy the connections reactions in order to have a safe unit.

In the model the effect of corrugated steel walls was not considered in order to stand on the safe side and so that the final outcome is an overestimated version. Those wall massively contribute 
to the stiffness of the model which almost eliminate the need for strengthening in any normal loaded residential building.

In conclusion, ISO container shipping building is found to be one of the fastest and most environmentally friendly building method for the residential and even commercial use. Taking advantage of the in-built characteristics it proves to be one of the prospective building method in the following years, regarding the increasing population of Canada. The building process was found to be economical compared to the conventional building practice which makes this types of building more interesting to the contractor. The potential lean of the builders into Container shipping structure could lead market's direction into its development further. 
Appendix A: Load Combinations 
Load combination were created according to NBCC 2015 and applied at the structure as following.

Table 13. Load Combinations applied on ETABS

\begin{tabular}{|c|c|c|c|c|}
\hline Name & $\begin{array}{c}\text { Load } \\
\text { Case } / \text { Com } \\
\text { bo }\end{array}$ & $\begin{array}{l}\text { Scale } \\
\text { Factor }\end{array}$ & Type & Auto \\
\hline UDStIS1 & DEAD & 1 & $\begin{array}{l}\text { Linear } \\
\text { Add }\end{array}$ & No \\
\hline UDStIS2 & DEAD & 1 & $\begin{array}{l}\text { Linear } \\
\text { Add }\end{array}$ & No \\
\hline UDStIS2 & LIVE & 1 & & No \\
\hline $\begin{array}{c}\text { UDStIS1 } \\
1\end{array}$ & DEAD & 1 & $\begin{array}{l}\text { Linear } \\
\text { Add }\end{array}$ & No \\
\hline $\begin{array}{c}\text { UDStIS1 } \\
1\end{array}$ & LIVE & 1 & & No \\
\hline $\begin{array}{c}\text { UDStIS1 } \\
1\end{array}$ & WPX & 1 & & No \\
\hline $\begin{array}{c}\text { UDStIS1 } \\
2\end{array}$ & DEAD & 1 & $\begin{array}{l}\text { Linear } \\
\text { Add }\end{array}$ & No \\
\hline $\begin{array}{c}\text { UDStIS1 } \\
2\end{array}$ & LIVE & 1 & & No \\
\hline $\begin{array}{c}\text { UDStIS1 } \\
2\end{array}$ & WPX & -1 & & No \\
\hline $\begin{array}{c}\text { UDStIS1 } \\
3\end{array}$ & DEAD & 1 & $\begin{array}{l}\text { Linear } \\
\text { Add }\end{array}$ & No \\
\hline $\begin{array}{c}\text { UDStIS1 } \\
3\end{array}$ & LIVE & 1 & & No \\
\hline $\begin{array}{c}\text { UDStIS1 } \\
3\end{array}$ & WPZ & 1 & & No \\
\hline $\begin{array}{c}\text { UDStIS1 } \\
4\end{array}$ & DEAD & 1 & $\begin{array}{l}\text { Linear } \\
\text { Add }\end{array}$ & No \\
\hline $\begin{array}{c}\text { UDStIS1 } \\
4\end{array}$ & LIVE & 1 & & No \\
\hline $\begin{array}{c}\text { UDStIS1 } \\
4\end{array}$ & WPZ & -1 & & No \\
\hline $\begin{array}{c}\text { UDStIS1 } \\
5\end{array}$ & DEAD & 1 & $\begin{array}{l}\text { Linear } \\
\text { Add }\end{array}$ & No \\
\hline $\begin{array}{c}\text { UDStIS1 } \\
5\end{array}$ & WPX & 1 & & No \\
\hline $\begin{array}{c}\text { UDStIS1 } \\
6\end{array}$ & DEAD & 1 & $\begin{array}{l}\text { Linear } \\
\text { Add }\end{array}$ & No \\
\hline $\begin{array}{c}\text { UDStIS1 } \\
6\end{array}$ & WPX & -1 & & No \\
\hline $\begin{array}{c}\text { UDStIS1 } \\
7\end{array}$ & DEAD & 1 & $\begin{array}{l}\text { Linear } \\
\text { Add }\end{array}$ & No \\
\hline $\begin{array}{c}\text { UDStIS1 } \\
7\end{array}$ & WPZ & 1 & & No \\
\hline $\begin{array}{c}\text { UDStIS1 } \\
8\end{array}$ & DEAD & 1 & $\begin{array}{l}\text { Linear } \\
\text { Add }\end{array}$ & No \\
\hline $\begin{array}{c}\text { UDStIS1 } \\
8\end{array}$ & WPZ & -1 & & No \\
\hline $\begin{array}{c}\text { UDStIS1 } \\
9\end{array}$ & DEAD & 1 & $\begin{array}{l}\text { Linear } \\
\text { Add }\end{array}$ & No \\
\hline $\begin{array}{c}\text { UDStIS1 } \\
9\end{array}$ & WPX & 1 & & No \\
\hline $\begin{array}{c}\text { UDStIS2 } \\
0\end{array}$ & DEAD & 1 & $\begin{array}{l}\text { Linear } \\
\text { Add }\end{array}$ & No \\
\hline $\begin{array}{c}\text { UDStIS2 } \\
0\end{array}$ & WPX & -1 & & No \\
\hline $\begin{array}{c}\text { UDStIS2 } \\
1\end{array}$ & DEAD & 1 & $\begin{array}{l}\text { Linear } \\
\text { Add }\end{array}$ & No \\
\hline $\begin{array}{c}\text { UDStIS2 } \\
1\end{array}$ & WPZ & 1 & & No \\
\hline $\begin{array}{c}\text { UDStIS2 } \\
2\end{array}$ & DEAD & 1 & $\begin{array}{l}\text { Linear } \\
\text { Add }\end{array}$ & No \\
\hline $\begin{array}{c}\text { UDStIS2 } \\
2\end{array}$ & WPZ & -1 & & No \\
\hline $\begin{array}{c}\text { UDStIS2 } \\
3\end{array}$ & DEAD & 1 & $\begin{array}{l}\text { Linear } \\
\text { Add }\end{array}$ & No \\
\hline
\end{tabular}




\begin{tabular}{|c|c|c|c|c|}
\hline $\begin{array}{c}\text { UDStIS2 } \\
3\end{array}$ & LIVE & 1 & & No \\
\hline $\begin{array}{c}\text { UDStIS2 } \\
3\end{array}$ & EQX & 1 & & No \\
\hline $\begin{array}{c}\text { UDStIS2 } \\
4\end{array}$ & DEAD & 1 & $\begin{array}{l}\text { Linear } \\
\text { Add }\end{array}$ & No \\
\hline $\begin{array}{c}\text { UDStIS2 } \\
4\end{array}$ & LIVE & 1 & & No \\
\hline $\begin{array}{c}\text { UDStIS2 } \\
4\end{array}$ & EQX & -1 & & No \\
\hline $\begin{array}{c}\text { UDStIS2 } \\
5\end{array}$ & DEAD & 1 & $\begin{array}{l}\text { Linear } \\
\text { Add }\end{array}$ & No \\
\hline $\begin{array}{c}\text { UDStIS2 } \\
5\end{array}$ & LIVE & 1 & & No \\
\hline $\begin{array}{c}\text { UDStIS2 } \\
5\end{array}$ & EQZ & 1 & & No \\
\hline $\begin{array}{c}\text { UDStIS2 } \\
6\end{array}$ & DEAD & 1 & $\begin{array}{l}\text { Linear } \\
\text { Add }\end{array}$ & No \\
\hline $\begin{array}{c}\text { UDStIS2 } \\
6\end{array}$ & LIVE & 1 & & No \\
\hline $\begin{array}{c}\text { UDStIS2 } \\
6\end{array}$ & EQZ & -1 & & No \\
\hline $\begin{array}{c}\text { UDStIS2 } \\
7\end{array}$ & DEAD & 1 & $\begin{array}{l}\text { Linear } \\
\text { Add }\end{array}$ & No \\
\hline $\begin{array}{c}\text { UDStIS2 } \\
7\end{array}$ & EQX & 1 & & No \\
\hline $\begin{array}{c}\text { UDStIS2 } \\
8\end{array}$ & DEAD & 1 & $\begin{array}{l}\text { Linear } \\
\text { Add }\end{array}$ & No \\
\hline $\begin{array}{c}\text { UDStIS2 } \\
8\end{array}$ & EQX & -1 & & No \\
\hline $\begin{array}{c}\text { UDStIS2 } \\
9\end{array}$ & DEAD & 1 & $\begin{array}{l}\text { Linear } \\
\text { Add }\end{array}$ & No \\
\hline $\begin{array}{c}\text { UDStIS2 } \\
9\end{array}$ & EQZ & 1 & & No \\
\hline $\begin{array}{c}\text { UDStIS3 } \\
0\end{array}$ & DEAD & 1 & $\begin{array}{l}\text { Linear } \\
\text { Add }\end{array}$ & No \\
\hline $\begin{array}{c}\text { UDStIS3 } \\
0\end{array}$ & EQZ & -1 & & No \\
\hline UDStID1 & DEAD & 1 & $\begin{array}{l}\text { Linear } \\
\text { Add }\end{array}$ & No \\
\hline UDStID2 & DEAD & 1 & $\begin{array}{l}\text { Linear } \\
\text { Add }\end{array}$ & No \\
\hline UDStID2 & LIVE & 1 & & No \\
\hline DCmpD1 & DEAD & 1 & $\begin{array}{l}\text { Linear } \\
\text { Add }\end{array}$ & Yes \\
\hline DCmpD1 & $\begin{array}{c}\text { SUPER } \\
\text { DEAD }\end{array}$ & 1 & & No \\
\hline DCmpD2 & DEAD & 1 & $\begin{array}{l}\text { Linear } \\
\text { Add }\end{array}$ & Yes \\
\hline DCmpD2 & LIVE & 1 & & No \\
\hline DCmpD2 & $\begin{array}{c}\text { SUPER } \\
\text { DEAD }\end{array}$ & 1 & & No \\
\hline DCmpS1 & DEAD & 1.25 & $\begin{array}{l}\text { Linear } \\
\text { Add }\end{array}$ & Yes \\
\hline DCmpS1 & $\begin{array}{c}\text { SUPER } \\
\text { DEAD }\end{array}$ & 1.25 & & No \\
\hline DCmpS2 & DEAD & 1.25 & $\begin{array}{l}\text { Linear } \\
\text { Add }\end{array}$ & Yes \\
\hline DCmpS2 & LIVE & 1.5 & & No \\
\hline DCmpS2 & $\begin{array}{c}\text { SUPER } \\
\text { DEAD }\end{array}$ & 1.25 & & No \\
\hline DCmpC1 & DEAD & 1.25 & $\begin{array}{l}\text { Linear } \\
\text { Add }\end{array}$ & Yes \\
\hline DStIS1 & DEAD & 1.4 & $\begin{array}{l}\text { Linear } \\
\text { Add }\end{array}$ & Yes \\
\hline DStIS1 & $\begin{array}{c}\text { SUPER } \\
\text { DEAD }\end{array}$ & 1.4 & & No \\
\hline DStIS2 & DEAD & 1.25 & $\begin{array}{l}\text { Linear } \\
\text { Add }\end{array}$ & Yes \\
\hline DStIS2 & LIVE & 1.5 & & No \\
\hline DStIS2 & $\begin{array}{c}\text { SUPER } \\
\text { DEAD }\end{array}$ & 1.25 & & No \\
\hline
\end{tabular}




\begin{tabular}{|c|c|c|c|c|}
\hline DStIS3 & DEAD & 1.25 & $\begin{array}{l}\text { Linear } \\
\text { Add }\end{array}$ & Yes \\
\hline DStIS3 & LIVE & 1.5 & & No \\
\hline DStIS3 & $\begin{array}{c}\text { SUPER } \\
\text { DEAD }\end{array}$ & 1.25 & & No \\
\hline DStIS3 & WPX & 0.4 & & No \\
\hline DStIS4 & DEAD & 1.25 & $\begin{array}{l}\text { Linear } \\
\text { Add }\end{array}$ & Yes \\
\hline DStIS4 & LIVE & 1.5 & & No \\
\hline DStIS4 & $\begin{array}{c}\text { SUPER } \\
\text { DEAD }\end{array}$ & 1.25 & & No \\
\hline DStIS4 & WPX & -0.4 & & No \\
\hline DStlS5 & DEAD & 1.25 & $\begin{array}{c}\text { Linear } \\
\text { Add }\end{array}$ & Yes \\
\hline DStIS5 & LIVE & 1.5 & & No \\
\hline DStIS5 & $\begin{array}{l}\text { SUPER } \\
\text { DEAD }\end{array}$ & 1.25 & & No \\
\hline DStIS5 & WPZ & 0.4 & & No \\
\hline DStIS6 & DEAD & 1.25 & $\begin{array}{c}\text { Linear } \\
\text { Add }\end{array}$ & Yes \\
\hline DStIS6 & LIVE & 1.5 & & No \\
\hline DStIS6 & $\begin{array}{c}\text { SUPER } \\
\text { DEAD }\end{array}$ & 1.25 & & No \\
\hline DStIS6 & WPZ & -0.4 & & No \\
\hline DStIS7 & DEAD & 1.25 & $\begin{array}{l}\text { Linear } \\
\text { Add }\end{array}$ & Yes \\
\hline DStIS7 & LIVE & 0.5 & & No \\
\hline DStIS7 & $\begin{array}{c}\text { SUPER } \\
\text { DEAD }\end{array}$ & 1.25 & & No \\
\hline DStIS7 & WPX & 1.4 & & No \\
\hline DStIS8 & DEAD & 1.25 & $\begin{array}{c}\text { Linear } \\
\text { Add }\end{array}$ & Yes \\
\hline DStIS8 & LIVE & 0.5 & & No \\
\hline DStIS8 & $\begin{array}{c}\text { SUPER } \\
\text { DEAD }\end{array}$ & 1.25 & & No \\
\hline DStIS8 & WPX & -1.4 & & No \\
\hline DStIS9 & DEAD & 1.25 & $\begin{array}{l}\text { Linear } \\
\text { Add }\end{array}$ & Yes \\
\hline DStIS9 & LIVE & 0.5 & & No \\
\hline DStIS9 & $\begin{array}{c}\text { SUPER } \\
\text { DEAD }\end{array}$ & 1.25 & & No \\
\hline DStIS9 & WPZ & 1.4 & & No \\
\hline DStIS10 & DEAD & 1.25 & $\begin{array}{c}\text { Linear } \\
\text { Add }\end{array}$ & Yes \\
\hline DStIS10 & LIVE & 0.5 & & No \\
\hline DStIS10 & $\begin{array}{l}\text { SUPER } \\
\text { DEAD }\end{array}$ & 1.25 & & No \\
\hline DStIS10 & WPZ & -1.4 & & No \\
\hline DStIS11 & DEAD & 1.25 & $\begin{array}{c}\text { Linear } \\
\text { Add }\end{array}$ & Yes \\
\hline DStIS11 & $\begin{array}{c}\text { SUPER } \\
\text { DEAD }\end{array}$ & 1.25 & & No \\
\hline DStIS11 & WPX & 1.4 & & No \\
\hline DStIS12 & DEAD & 1.25 & $\begin{array}{l}\text { Linear } \\
\text { Add }\end{array}$ & Yes \\
\hline DStIS12 & $\begin{array}{c}\text { SUPER } \\
\text { DEAD }\end{array}$ & 1.25 & & No \\
\hline DStIS12 & WPX & -1.4 & & No \\
\hline DStIS13 & DEAD & 1.25 & $\begin{array}{l}\text { Linear } \\
\text { Add }\end{array}$ & Yes \\
\hline DStIS13 & $\begin{array}{l}\text { SUPER } \\
\text { DEAD }\end{array}$ & 1.25 & & No \\
\hline DStIS13 & WPZ & 1.4 & & No \\
\hline DStIS14 & DEAD & 1.25 & $\begin{array}{l}\text { Linear } \\
\text { Add }\end{array}$ & Yes \\
\hline DStIS14 & $\begin{array}{c}\text { SUPER } \\
\text { DEAD }\end{array}$ & 1.25 & & No \\
\hline
\end{tabular}




\begin{tabular}{|c|c|c|c|c|}
\hline DStIS14 & WPZ & -1.4 & & No \\
\hline DStIS15 & DEAD & 0.9 & $\begin{array}{l}\text { Linear } \\
\text { Add }\end{array}$ & Yes \\
\hline DStIS15 & $\begin{array}{c}\text { SUPER } \\
\text { DEAD }\end{array}$ & 0.9 & & No \\
\hline DStIS15 & WPX & 1.4 & & No \\
\hline DStIS16 & DEAD & 0.9 & $\begin{array}{l}\text { Linear } \\
\text { Add }\end{array}$ & Yes \\
\hline DStIS16 & $\begin{array}{l}\text { SUPER } \\
\text { DEAD }\end{array}$ & 0.9 & & No \\
\hline DStIS16 & WPX & -1.4 & & No \\
\hline DStIS17 & DEAD & 0.9 & $\begin{array}{l}\text { Linear } \\
\text { Add }\end{array}$ & Yes \\
\hline DStIS17 & $\begin{array}{c}\text { SUPER } \\
\text { DEAD }\end{array}$ & 0.9 & & No \\
\hline DStIS17 & WPZ & 1.4 & & No \\
\hline DStIS18 & DEAD & 0.9 & $\begin{array}{c}\text { Linear } \\
\text { Add }\end{array}$ & Yes \\
\hline DStIS18 & $\begin{array}{c}\text { SUPER } \\
\text { DEAD }\end{array}$ & 0.9 & & No \\
\hline DStIS18 & WPZ & -1.4 & & No \\
\hline DStIS19 & DEAD & 1 & $\begin{array}{l}\text { Linear } \\
\text { Add }\end{array}$ & Yes \\
\hline DStIS19 & LIVE & 0.5 & & No \\
\hline DStIS19 & $\begin{array}{c}\text { SUPER } \\
\text { DEAD }\end{array}$ & 1 & & No \\
\hline DStIS19 & EQX & 1 & & No \\
\hline DStIS20 & DEAD & 1 & $\begin{array}{l}\text { Linear } \\
\text { Add }\end{array}$ & Yes \\
\hline DStIS20 & LIVE & 0.5 & & No \\
\hline DStIS20 & $\begin{array}{c}\text { SUPER } \\
\text { DEAD }\end{array}$ & 1 & & No \\
\hline DStIS20 & EQX & -1 & & No \\
\hline DStIS21 & DEAD & 1 & $\begin{array}{c}\text { Linear } \\
\text { Add }\end{array}$ & Yes \\
\hline DStIS21 & LIVE & 0.5 & & No \\
\hline DStIS21 & $\begin{array}{c}\text { SUPER } \\
\text { DEAD }\end{array}$ & 1 & & No \\
\hline DStIS21 & EQZ & 1 & & No \\
\hline DStIS22 & DEAD & 1 & $\begin{array}{c}\text { Linear } \\
\text { Add }\end{array}$ & Yes \\
\hline DStIS22 & LIVE & 0.5 & & No \\
\hline DStIS22 & $\begin{array}{c}\text { SUPER } \\
\text { DEAD }\end{array}$ & 1 & & No \\
\hline DStIS22 & EQZ & -1 & & No \\
\hline DStIS23 & DEAD & 1 & $\begin{array}{l}\text { Linear } \\
\text { Add }\end{array}$ & Yes \\
\hline DStIS23 & $\begin{array}{c}\text { SUPER } \\
\text { DEAD }\end{array}$ & 1 & & No \\
\hline DStIS23 & EQX & 1 & & No \\
\hline DStIS24 & DEAD & 1 & $\begin{array}{c}\text { Linear } \\
\text { Add }\end{array}$ & Yes \\
\hline DStIS24 & $\begin{array}{c}\text { SUPER } \\
\text { DEAD }\end{array}$ & 1 & & No \\
\hline DStIS24 & EQX & -1 & & No \\
\hline DStIS25 & DEAD & 1 & $\begin{array}{c}\text { Linear } \\
\text { Add }\end{array}$ & Yes \\
\hline DStlS25 & $\begin{array}{c}\text { SUPER } \\
\text { DEAD }\end{array}$ & 1 & & No \\
\hline DStIS25 & EQZ & 1 & & No \\
\hline DStIS26 & DEAD & 1 & $\begin{array}{c}\text { Linear } \\
\text { Add }\end{array}$ & Yes \\
\hline DStIS26 & $\begin{array}{c}\text { SUPER } \\
\text { DEAD }\end{array}$ & 1 & & No \\
\hline DStIS26 & EQZ & -1 & & No \\
\hline DStID1 & DEAD & 1 & $\begin{array}{c}\text { Linear } \\
\text { Add }\end{array}$ & Yes \\
\hline
\end{tabular}




\begin{tabular}{|c|c|c|c|c|}
\hline DStID1 & $\begin{array}{c}\text { SUPER } \\
\text { DEAD }\end{array}$ & 1 & No & Yes \\
\hline DStID2 & DEAD & 1 & $\begin{array}{c}\text { Linear } \\
\text { Add }\end{array}$ & Yes \\
\hline DStID2 & LIVE & 1 & & No \\
\hline DStID2 & $\begin{array}{c}\text { SUPER } \\
\text { DEAD }\end{array}$ & 1 & & No \\
\hline
\end{tabular}


Appendix B: Calculations 


\section{Specified Snow Load (NBC 2015)}

$\mathrm{S}=\mathrm{I}_{\mathrm{s}}\left[\mathrm{S}_{\mathrm{s}}\left(\mathrm{C}_{\mathrm{b}} \mathrm{C}_{\mathrm{w}} \mathrm{C}_{\mathrm{s}} \mathrm{C}_{\mathrm{a}}\right)+\mathrm{S}_{\mathrm{r}}\right]$ [4.1.6.2]

Location: Hamilton, Ontario

$\mathrm{Ss}=1.1 \mathrm{kPa} / \mathrm{Sr}=0.4 \mathrm{kPa}$

Importance Factor, ULS: $\mathrm{I}_{\mathrm{s}}=1.0 /$ SLS: $\mathrm{I}_{\mathrm{S}}=0.9$

Roof slope $=0$ degrees

Slope Factor

For non-slippery roof:

Slope $<=30$ degrees.

$\mathrm{C}_{\mathrm{s}}=1$

\section{ULS:}

$\mathrm{S}=1.0[0.9(0.8 * 1.0 * 1 * 1.0)+0.4]=1.12 \mathrm{kPa}$

$S=1.28 \mathrm{kPa}$

$S=26.7 p s f$

SLS:

$\mathrm{S}=0.9[0.9(0.8 * 1.0 * 1 * 1.0)+0.4]=1.01 \mathrm{kPa}$

$S=1.15 \mathrm{kPa}$

$S=24.1 p s f$

\section{Specified Wind Load (NBC 2015)}

Location: Hamilton, Ontario

q50: $0.46 \mathrm{kPa}$

Importance Factor, ULS: $I_{w}=1.0 /$ SLS: $I_{w}=0.75$

Roof slope $=0$ degrees

$\mathrm{C}_{\mathrm{e}}=(\mathrm{h} / 10)^{0.2}=0.92$

$\mathrm{C}_{\mathrm{t}}=1$

\section{External Wind Pressure}

$\mathrm{p}=\mathrm{I}_{\mathrm{w}} * \mathrm{q} * \mathrm{C}_{\mathrm{e}} * \mathrm{C}_{\mathrm{t}} * \mathrm{C}_{\mathrm{g}} * \mathrm{C}_{\mathrm{p}}$

Load Case A: Winds generally perpendicular to ridge

Load Case B: Winds generally parallel to ridge 
Table 14. External Wind Pressure

\begin{tabular}{|c|c|c|c|c|c|c|}
\hline \multirow[b]{2}{*}{ Side } & \multicolumn{3}{|c|}{ Load Case A } & \multicolumn{3}{|c|}{ Load Case B } \\
\hline & $\mathrm{C}_{\mathrm{p}} \mathrm{C}_{\mathrm{g}}$ & $\begin{array}{c}\text { ULS } \\
\mathrm{p} \\
(\mathrm{kPa})\end{array}$ & $\begin{array}{c}\text { SLS } \\
\mathrm{p} \\
(\mathrm{kPa})\end{array}$ & $\mathrm{C}_{\mathrm{p}} \mathrm{C}_{\mathrm{g}}$ & $\begin{array}{c}\text { ULS } \\
\mathrm{p} \\
(\mathrm{kPa})\end{array}$ & $\begin{array}{c}\text { SLS } \\
\mathrm{p} \\
(\mathrm{kPa})\end{array}$ \\
\hline 1 & 0.75 & 0.32 & 0.24 & -0.85 & -0.36 & -0.27 \\
\hline 1E & 1.15 & 0.48 & 0.36 & -0.9 & -0.38 & -0.28 \\
\hline 2 & $\mid-1.3$ & -0.55 & -0.41 & $\mid-1.3$ & $=0.55$ & -0.41 \\
\hline $2 \mathrm{E}$ & -2 & .84 & -0.63 & -2.0 & -0.84 & -0.6 \\
\hline 3 & -0.7 & -0.29 & -0.22 & -0.7 & -0.29 & -0.22 \\
\hline $3 \mathbf{E}$ & -1 & -0.42 & -0.32 & -1.0 & -0.42 & -0.32 \\
\hline 4 & -0.55 & -0.23 & -0.17 & -0.85 & -0.36 & -0.27 \\
\hline 4E & -0.8 & -0.34 & -0.25 & -0.9 & -0.38 & -0.28 \\
\hline 5 & $\mathrm{n} / \mathrm{a}$ & $n / a$ & $n / a$ & 0.75 & 0.32 & 0.24 \\
\hline $5 E$ & $\mathrm{n} / \mathrm{a}$ & $\mathrm{n} / \mathrm{a}$ & $\mathrm{n} / \mathrm{a}$ & 1.15 & 0.48 & 0.36 \\
\hline 6 & $n / a$ & $n / a$ & $n / a$ & -0.55 & $=0.23$ & -0.17 \\
\hline $6 \mathrm{E}$ & $\mathrm{n} / \mathrm{a}$ & $\mathrm{n} / \mathrm{a}$ & $n / a$ & -0.8 & -0.34 & -0.25 \\
\hline
\end{tabular}

\section{Internal Wind Pressure}

$\mathrm{C}_{\mathrm{gi}}=2$

$\mathrm{C}_{\mathrm{pi}}=-0.15$ to 0

$\mathrm{p}_{\mathrm{i}}=\mathrm{I}_{\mathrm{w}} * \mathrm{q} * \mathrm{C}_{\mathrm{e}} * \mathrm{C}_{\mathrm{t}} * \mathrm{C}_{\mathrm{gi}} * \mathrm{C}_{\mathrm{pi}}$

ULS: $p_{i}=-\mathbf{0 . 1 3 k P a}$ to $0 \mathrm{kPa}$

SLS: $p_{i}=-0.09 k P a$ to $0 \mathrm{kPa}$ 


\section{Earthquake Load Equivalent Static Method (NBC 2015)}

Location: Hamilton, Ontario

$\mathrm{Sa}(0.2)=0.26$

$\mathrm{Sa}(0.5)=0.128$

$\mathrm{Sa}(1.0)=0.061$

$\operatorname{Sa}(2.0)=0.028$

$\mathrm{Sa}(5.0)=0.0068$

$\mathrm{Sa}(10.0)=0.0027$

$\mathrm{PGA}=0.168$

$\mathrm{PGV}=0.101$

Site class $=\mathrm{D}$

Importance Factor, $\mathrm{I}_{\mathrm{E}}=1.0$

Material $=$ steel

System $=$ moment

SFRS = Conventional construction of moment-resisting frames, braced frames or plate walls (Assembly occupancies)

$\mathrm{h}_{\mathrm{n}}=6.45 \mathrm{~m}$

$\mathrm{T}_{\mathrm{a}}=$ Computed for given height $\&$ system .

PGA $_{\text {ref }}=0.134$

$\mathrm{F}(0.2)=1.19$

$\mathrm{F}(0.5)=1.41$

$\mathrm{F}(1.0)=1.49$

$\mathrm{F}(2.0)=1.53$

$\mathrm{F}(5.0)=1.55$

$\mathrm{F}(10.0)=1.46$

$\mathrm{R}_{\mathrm{d}}=1.5$

$\mathrm{R}_{\mathrm{o}}=1.3$

$\mathrm{S}(0.2)=0.31$

$\mathrm{S}(0.5)=0.18$ 
$S(1.0)=0.09$

$S(2.0)=0.04$

$S(4.0)=0.02$

$\mathrm{S}(5.0)=0.01$

$\mathrm{S}(10.0)=0$

$\mathrm{T}_{\mathrm{a} \text { computed }}=0.34 \mathrm{~s}$

$\mathrm{M}_{\mathrm{v}}=1$

$\mathrm{S}\left(\mathrm{T}_{\mathrm{a}}\right)=\mathrm{S}(0.34)=0.247$ 


\section{References}

1. https://www.drewry.co.uk

2. Borvik, T., Burbach, A., Langberg, H., \& Langseth, M. (2008). On the ballistic and blast load response of a $20 \mathrm{ft}$ ISO container protected with aluminum panels filled with a local mass - Phase II: Validation of protective system. 2008; 30:1621-31. Engineering Strucutres, 30(6), 1621-1631.

3. Brandt, K. (2011). Plugging, in: Reinterpreting the Traditional Housing Archetype Within a Community Using Shipping Containers. Master's Thesis, University of North Carolina.

4. https://www.drewry.co.uk/

5. Fuller, M. (2006). Strong, Affordable Storm-Ready Housing Project: Building with Steel Shipping Containers and Super Therm. Retrieved from www.eaglecoating.net: http://www.eaglecoatings.net/content/supertherm/pdfs/Container_Homes_Bob_Vila.pdf

6. Giriunas, K., Sezen, H., \& Dupaix, R. B. (2015). Evaluation, modeling, and analysis of shipping container building structures. Engineering Structures, 43, 48-57.

7. http://www.globalportablebuildings.com

8. www.inhabitat.com/2008/08/22/travelodge-shipping-container-hotel

9. Islam, H., Zhang, G., Setunge, S., \& Bhuiyan, M. A. (2016). Life cycle assessment of shipping container home: A sustainable construction. Energy and Buildings, 128, 673685.

10. ISO1161. (1990). ISO/TC 104. ISO 1161:1984/Cor 1:1990 technical corrigendum 1:1990 to ISO 1161:1984. International Organization for Standardization. Geneva, Switzerland.

11. ISO1496-1. (1990). ISO/TC 104. ISO 1496-1:1990 Series 1 freight containersspecification and testing - Part 1: General cargo containers for general purposes. nternational Organization for Standardization. Geneva, Switzerland.

12. ISO2308. (1972). ISO/TC 104. ISO 2308:1972 hooks for lifting freight containers of up to 30 tons capacity-basic requirements. International Organization for Standardization. Geneva, Switzerland.

13. ISO3874. (1997). ISO/TC 104. ISO 3874:1997 series 1 freight containers-handling and securing. International Organization for Standardization. Geneva, Switzerland.

14. ISO6346. (1995). ISO/TC 104. ISO 6346:1995 freight containers-coding. International Organization for Standardization. Geneva, Switzerland.

15. ISO668. (1995). ISO/TC 104. ISO 668:1995 series 1 freight containers-classification, dimensions and ratings. International Organization for Standardization. Geneva, Switzerland. 
16. ISO830. (1999). ISO/TC 104. ISO 830:1999 freight containers-vocabulary. nternational Organization for Standardization. Geneva, Switzerland.

17. Kotnik, J. (2008). Container Architecture. Barcelona: LINKS International.

18. Martinez-Garcia, M. (2014). Alternative Housing: the Shipping Container Home. Retrieved from National Association of Realtor: https://crt.blogs.realtor.org/files/2014/12/shipping-container-homes-white-paper-201412-10.pdf

19. http://michaelbgreen.com.au/node/69

20. Moore, C. M., Yildirim, S. G., \& Baur, S. W. (2015). Educational Adaptation of Cargo Container Design Features. ASEE Zone III Conference.

21. Oloto, E., \& A.Adebayo. (2015). Building with Shipping Containers: A Sustainable Approach to Solving Housing Shortages in Lagos Metropolis. University of Lagos, Department of Architecture,.

22. Pena, J., \& S.Kurt. (2012). Design of resusable emergency relief housing units generalpurpose(GP) shipping container. International journal of Engieering Research Inoovation, 4(2), 55-64.

23. Pena, J., \& Schuzer, K. (2012). Design of Reusable Emergency Relief Housing Units Using General Purpose Shipping Containers. International Journal of Engineering Research and Innovation, 4(2), 55-64.

24. Smith, J. (2005). Shipping Containers as Building Components, the Creative Common Attribution-non-commercial. University of Brighton, Department of built environment.

25. Uittenbroek, C., \& Macht, W. (2009). Sustainable containers: cost-effective student housing. Quarterly \& Urban Development Journal, 53-60.

26. Vijayalaxmi. (2010). Towards sustainable architecture-a case with Greentainer. Local Environment, 15(3), 245-259.

27. Zhang, G., Setunge, S., \& Elmpt, S. v. (2014). using shipping containers to provide temporary housing in post-disaster recovery: Social case studies. Procedia Economics and Finance, 18, 618-625. 